\author{
UNIVERSIDADE DE SÃO PAULO \\ FACULDADE DE FILOSOFIA, LETRAS E CIÊNCIAS HUMANAS \\ DEPARTAMENTO DE LETRAS MODERNAS \\ PROGRAMA DE PÓS-GRADUAÇÃO EM LÍNGUA E LITERATURAS \\ ESPANHOLA E HISPANO-AMERICANA
}

\title{
REHACER Y RESISTIR: EL PROCESO DE ESCRITURA DE OPERACIÓN MASACRE DE RODOLFO WALSH
}

\section{Graciela Foglia}

Tese apresentada ao Programa de PósGraduação em Língua Espanhola e Literaturas Espanhola e Hispano-americana, do Departamento de Letras Modernas da Faculdade de Filosofia, Letras e Ciências Humanas da Universidade de São Paulo, para obtenção do título de Doutor em Letras.

Orientadora: Profa. Dra. Valeria De Marco

São Paulo

200 
A mis padres, Juan y Esther, aunque lo vivieron de otra forma

A los chicos, Catalina y Mateo, para que entiendan que, aun en los peores tiempos, hay caminos de resistencia

A los de siempre, Claudia y Edgar, por todo lo que no supimos en aquellos años 


\section{Agradecimientos}

A mi orientadora, Valeria De Marco, porque con su práctica coherente, académica y de vida, resiste a la otra práctica, la de exclusión, marca de nuestro tiempo; y también, no menos importante, porque con su estímulo me posibilitó pensar en ese desconcertante país que es la Argentina, y de esa forma abrir(me) algunos caminos de reconciliación con su historia.

Y en la línea de las reconciliaciones, a Jung Ha Kang y Mariana De Gainza, porque forman parte de otro tiempo y otro (?) país, que vivo desde lejos.

A mi querido amigo y compañero Ivan Rodrigues Martin, porque su solidaridad y su humor cuestionador son otras tantas formas de resistencia.

A mi queridísima Andréa Ponte, porque siempre sabe la medida justa de las cosas y a Paulo Rosi, por su amistad.

A Dária Jaremtchuk, por su solidaridad incondicional y a Luis Ferla, también por su solidaridad y, sobre todo, por su humor.

A Sérgio Alves, Mayra Pinto y Talia Bugel, amigos entrañables, que están desde siempre en mi historia en este país, no menos desconcertante que aquel otro del que vengo.

A Sonia Izquierdo, Paulo Thomas y el pequeño Nicolás, porque forman parte de mi día a día.

A Flávio Finardi, por los encuentros gastronómicos tantos domingos de tesis.

A Claudia Jacobi, amiga querida, por el cuidado y el abrigo precisos; y a Felipe Da Viña por la ayuda informática y las charlas políticas.

A Rosângela Dantas, porque con su cariño y practicidad me tranquilizó en muchos momentos. 
A mis compañeros de la PUC, Claudia, Ivan, Mônica Mayrink, John O' Kuinghttons y Rosângela porque "me hicieron el aguante" el tiempo de la escritura.

A Luciana Kopelman, por los años que hace que me escucha.

A Diego Liguori y Guillermo Loyola, porque siempre están presentes.

A María de la Concepción Piñero Valverde, porque hace muchos años, cuando toda esta historia personal empezó, confió.

Al grupo de estudios de testimonio, Andrea Lombardi, Annie Dymetman, Berta Waldman, Eva, Helmut Galle, Luana, Luiza Martins da Silva, Márcio Seligmann, Nancy Rozenchan, Saul Kirschbein, Silvia Adoue, Suely Pfeferman, Susana Lages, Valeria De Marco, por tantos viernes de lecturas y discusiones.

Al otro grupo de lecturas y amigos: Adriana, Ângela, Daniela, Ivan, Luiza, Luzimeire, Silvio, Susana, Valeria, Virginia, porque sí; porque también forman parte de mi historia académica y de vida.

A Zulma Kulikowski, por su amabilidad y disposición ante mis dudas lingüísticas.

A los profesores del Programa de Pós-graduação en Língua Espanhola e Literatura Espanhola e Hispano-americana, porque siempre es posible contar con ellos.

A los profesores Ana Cecilia Olmos y Júlio Pimentel, porque con sus sugerencias de lecturas, literarias e históricas, enriquecieron la reflexión para realizar este trabajo.

A Martincho, Andrea Pizutielo y Enrique Melone, porque no dudaron en ayudarme cuando lo necesité.

A la Comissão de Pesquisa do CEPE da Pontifícia Universidade Católica (PUC) de São Paulo, porque me otorgó "horas pesquisa" entre febrero y junio de 2004. 


\section{RESUMO}

O objetivo desta tese é analisar Operación masacre de Rodolfo Walsh à luz da reflexão sobre as relações entre literatura e testemunho. $O$ trabalho tem como hipótese que Operación masacre pode ser lida como um romance de testemunho não só porque em suas páginas denuncia a prática da violência de Estado mas, sobretudo, porque essa violência gera o imperativo ético de escrever e a procura de uma forma narrativa.

Palavras chave: Operación masacre - Rodolfo Walsh - literatura de testemunholiteratura e violência de Estado - narrativa argentina do século XX 


\section{RESUMEN}

El objetivo de esta tesis es analizar Operación masacre de Rodolfo Walsh teniendo como base la reflexión sobre las relaciones entre literatura y testimonio. El trabajo tiene como hipótesis que Operación masacre puede ser leída como una novela de testimonio no solo porque en sus páginas se denuncia la práctica de la violencia de Estado, sino sobretodo porque esa violencia genera el imperativo ético de escribir y la búsqueda de una forma narrativa.

Palabras clave: Operación masacre - Rodolfo Walsh - literatura de testimonio - literatura e violencia de Estado - narrativa argentina del siglo XX 


\section{SUMMARY}

The purpose of this thesis is to analise Operación masacre written by Rodolfo Walsh under the lights of reflection about the relations between literature and testimony. The work has as hypothesis that Operación masacre can be read as a testimony novel not only because in its pages denounces the State's violence, but above all, because this violence generates the ethical imperative of writing and the search for a narrative form.

Key words: Operación masacre - Rodolfo Walsh - testimony literature - literature and State's violence - argentine narrative from $X X^{\text {th }}$ century 


\section{ÍNDICE}

Introducción

Capítulo 1 - Rodolfo Walsh y su tiempo

Capítulo 2 - Modos de leer Operación masacre

Capítulo 3 - Palabras y resistencia

3.1 Del "qué" al "cómo": Prólogos e introducciones

3.2 Cómo acercarse a las víctimas: "Las Personas"

3.3 Cómo narrar la matanza: "Los hechos"

3.4 Cómo persuadir a los lectores: "La evidencia" 


\section{INTRODUCCIÓN}

La noche del 9 de junio de 1956, algunas personas se hallaban reunidas de casualidad en una casa del Gran Buenos Aires para escuchar una pelea de box; varias de ellas ni siquiera se conocían entre sí. En el momento en que se disponían a marcharse, irrumpe violentamente la policía y las lleva detenidas. Al principio no saben por qué; de a poco, mientras esperan en la comisaría, irán teniendo noticias de que se está produciendo un alzamiento militar, una revolución. A partir de ese momento comienzan a temer por sus vidas. Y no se equivocan: ha sido dada la orden de fusilarlas. La orden es cumplida, por la policía de la provincia de Buenos Aires, durante la madrugada del 10 de junio, en un basural de la localidad de José León Suárez. Al fusilamiento sobreviven, por lo menos, siete de los detenidos, uno de los cuales, meses después, denuncia el hecho ante la justicia. Rodolfo Walsh se entera de estos hechos y decide investigarlos y denunciarlos.

Operación masacre es la obra que escribe Rodolfo Walsh como producto de dicha investigación: la perplejidad que le genera descubrir la práctica de la violencia como política de Estado lleva al autor a escribir este texto que pone en tensión los cánones del periodismo y de la novela. En una "Nota autobiográfica" de 1965, el autor afirmaba:

Operación masacre cambió mi vida. Haciéndola, comprendí que además de mis perplejidades íntimas, existía un amenazante mundo exterior. (WALSH, 2000, p. 241).

A lo largo de los años, Operación masacre ha sido leída de diferentes maneras ${ }^{1}$, de acuerdo con los tiempos y los hábitos de lectura, pero hay tres miradas que predominan: la que la considera como una obra periodística, la que la lee a la luz de la novela policial y la que la refiere a la no-ficción (o testimonio), este último género considerado como el que surge cuando se agotan las formas tradicionales del periodismo. A mi ver, estas lecturas pueden ser insuficientes cuando se considera Operación masacre como texto literario.

En este trabajo me propongo leer Operación masacre como novela de testimonio. Más concretamente, la lectura aquí es orientada por las reflexiones desarrolladas en el ámbito

\footnotetext{
${ }^{1}$ El segundo capítulo de este trabajo está dedicado a comentar los estudios críticos.
} 
de estudios de la literatura de testimonio del Holocausto o Shoah ${ }^{2}$. Y, dentro de dichos estudios, las reflexiones del filósofo italiano Giorgio Agamben me parecen esenciales para poder pensar Operación masacre porque lo que se lee en la novela es que el Estado comete un crimen, pero para las propias instancias del mismo, no se configura como tal.

En Medios sin fin. Notas sobre la política, Giorgio Agamben se propone pensar algunos problemas de la política "en experiencias y en fenómenos que no son considerados de ordinario como políticos (o lo son de manera marginal)"; entre dichos fenómenos considera la cuestión del refugiado, que "al romper el vínculo entre hombre y ciudadano deja de ser una figura marginal y se convierte en factor decisivo de la crisis del Estadonación moderno" (AGAMBEN, 2001, p. 11). Siguiendo a Hannah Arendt, Agamben señala que, en tanto los derechos del hombre están indisolublemente ligados al Estado-nación, el ocaso de este último "implica necesariamente que aquellos se conviertan en obsoletos". Y recuerda que:

"... los primeros campos fueron construidos en Europa como espacios de control para refugiados, y que la sucesión campos de internamiento-campos de concentración-campos de exterminio representa una filiación perfectamente real". (p. 27)

\footnotetext{
${ }^{2}$ Puede leerse una discusión sistematizada sobre las diferentes corrientes en "A literatura de testemunho e a violência de Estado" (DE MARCO, 2004). El comentario a continuación está basado en dicha referencia. Existen dos grandes corrientes que piensan la literatura de testimonio: una dentro del campo de la crítica de la literatura testimonial hispanoamericana; la otra es la que surge de la reflexión sobre la Shoah; ambas se diferencian por sus interpretaciones del siglo XX. Dentro de la primera también hay dos corrientes: una, más abierta a considerar en general los textos que dan cuenta de las dictaduras de América Latina durante el siglo XX"; la otra, lectura casi totalmente hegemónica — cuyos trabajos de referencia son los de Elzbieta Sklodowska (1991) y los reunidos por John Beverley (1992) en la Revista de crítica literaria latinoamericana-. Para estos críticos, el testimonio se constituye en el encuentro de un intelectual comprometido con un "subalterno", o como dice De Marco, del encuentro entre un narrador "de oficio" y un narrador que no integra los espacios de producción de conocimiento considerados legítimos. De dicho encuentro (cuyo texto paradigmático es Me llamo Rigoberta Menchú y así me nació la conciencia, de 1983), surge el testimonio mediado por el intelectual (2004, p. 46). De ahí surgiría la posibilidad de un espacio discursivo ampliado en el cual es posible incluir/oír la voz del "subalterno", y así construir una nueva identidad "heterogénea, por diferenciada y plural, quizás más democrática, y que respete las identidades otras" (ACHUGAR, 1992, P. 53). Señala De Marco que es aquí, donde reside lo problemático de esta concepción de testimonio, pues a ella subyace "uma interpretação ideológica do século XX: um século marcado por un processo histórico de inclusão social. Essa leitura, ao não considerar a interloculção com a leitura deste século de tanta violência como processo histórico de exclusão social, dificulta a reflexão sobre a inserção particular da literatura de testemunho das últimas décadas da América Latina no mundo movente da literatura escrita por homens de diferentes línguas, utopias, etnias ou credos nesta nossa 'era da catástrofe', em que a violência e a barbárie, tanto quanto o capital, não encontram fronteiras geográficas, políticas ou étnicas." (pp. 49-50).
} 
Agamben usa la figura del refugiado - que en el siglo $X X$ se ha transformado en un fenómeno masivo - porque su aparición junto con "el nuevo orden creado por los tratados de paz [a finales de la Primera Guerra Mundial] alteraron con gran profundidad las bases demográficas y territoriales de la Europa centro-oriental”3. Además, a esto hay que añadir el hecho de que, en la misma época, muchos estados europeos promulgaron leyes que "permitían la desnaturalización y la desnacionalización de sus propios ciudadanos"4. "Estas leyes - y el apatridismo de masa derivado de ellas - marcan una transformación decisiva en la vida del Estado-nación moderno y su emancipación definitiva de las nociones ingenuas de pueblo y de ciudadano". Con la desnaturalización, los "derechos ya no son derechos del ciudadano [y] el hombre se hace verdaderamente sagrado en el sentido que tiene este término en el derecho romano arcaico: consagrado a la muerte"( $p$. 27).

Estas reflexiones le permiten al filósofo italiano considerar al Estado moderno como un espacio aporético de exclusión inclusiva y de inclusión exclusiva, en el cual al soberano se le atribuye, no el poder de dejar vivir, sino el de no dejar morir. Este mismo poder político está fundado en la separación de los hombres con derechos y deberes políticos, cuya vida es la del ciudadano (Bios), de aquellos de vida nuda (Zoé5), los excluidos, es decir, cuya vida puede ser aniquilada sin que eso se convierta en un crimen.

Dentro de esta concepción de Estado —y de vida— es que se puede pensar Operación masacre, ya que

O testemunho [...] vem da zona da vida nua e aponta [uma] concepção da literatura de testemunho [que] se sustenta sobre una interpretação do século XX como um processo histórico e social de sistemática exclusão. (DE MARCO, 2004, p. 56-57)

En Operación masacre, el espanto del narrador ante el crimen es descubrir que los "hombres comunes" — categoría social amplia de la que él mismo forma parte_ son, para

\footnotetext{
${ }^{3}$ Este fenómeno llega a los días de hoy y se proyecta al futuro con la llamada inmigración ilegal a los países de la Comunidad europea, (AGAMBEN, 2001, p. 27).

${ }^{4}$ Hasta llegar a las de Leyes de Núremberg que "dividieron a los ciudadanos alemanes en ciudadanos de pleno derecho y ciudadanos sin derechos políticos" (AGAMBEN, 2001, p. 23).

${ }^{5}$ Para los griegos, la palabra zoé expresaba "el simple hecho de vivir común a todos los vivientes (animales, hombres o dioses)" y bios, "significaba la forma o manera de vivir propia de un individuo o de un grupo." (AGAMBEN, 2001, p.13).
} 
el Estado, portadores de vida nuda, de vida aniquilable. Frente a esto, la novela se configurará como el lugar de la búsqueda del narrador por comprender un mundo que de repente se le volvió hostil y violento. Operación masacre será escrita y reescrita, a lo largo de quince años: serán modificados prólogos y epílogos; serán agregadas algunas partes, desechadas otras; el narrador ensayará diferentes lugares desde donde relatar los hechos, en busca de comprender la violencia desatada aquella noche del 9 de junio de 1956. Pero la respuesta no llegará; hay una estructura básica de Operación masacre que nunca cambiará, que permanecerá la misma como testigo de que algo se quebró para siempre. Ambas características — la búsqueda de sentido y la imposibilidad de retornar a un estado de armonía - hacen que Operación masacre pueda ser leída como novela de testimonio: testimonio, porque su universo es el de la vida nuda; novela, porque ese universo impone la necesidad de buscar el sentido de la vida ${ }^{6}$.

El presente trabajo pretende acompañar esa búsqueda walshiana. Presentaré en primer lugar un breve panorama histórico, para hacer inteligibles ciertos rasgos de la biografía y la producción literaria del autor. A continuación, reseñaré las principales líneas de lectura de Operación masacre presentes en la literatura crítica, desde su primera publicación hasta la actualidad. Para finalmente abocarme al análisis e interpretación del texto, siguiendo las divisiones que lo organizan. Luego de las conclusiones y de la bibliografía, incluyo un anexo con una entrevista realizada en 1973 a Julio Troxler, sobreviviente de la masacre de 1956, asesinado por la Triple A (Alianza Anticomunista Argentina) en 1974.

\footnotetext{
${ }^{6}$ Aquí pienso en las formulaciones de Georg Lukács sobre la novela. Esta sería la forma que surge cuando se quiebra la armonía entre alma y mundo, entre existencia y esencia; "...é sempre o sintoma de una laceração entre o interior e o exterior, significativa de uma diferença essencial entre o eu e o mundo, de uma não-adequção entre a alma e a ação (LUKÁCS, 2000, p.26). Ante ese desgarramiento, la búsqueda del héroe "demoníaco" de Lukács (o "problemático", en la formulación de Goldman) es la que determina la forma de la novela, que "...busca descobrir e construir [...] a totalidade oculta da vida [...] Assim, a intenção fundamental determinante da forma do romance objetiva-se como psicologia dos heróis romanescos: eles buscam algo." (LUKÁCS, 2000, p. 60)
} 


\section{CAPÍTULO 1: RODOLFO WALSH Y SU TIEMPO}

Los fusilamientos de 1956 se producen en un momento en que una parte de la sociedad argentina apostaba al régimen que había derrocado al general Perón, la autodenominada "Revolución Libertadora" - eufemismo para referirse al golpe militar de septiembre de 1955-, cuyo objetivo esencial, según proclamaba, era:

Suprimir todos los vestigios de totalitarismo para restablecer el imperio de la moral, de la justicia, del derecho, de la libertad y de la democracia... ${ }^{7}$

Antes de este golpe de setiembre 1955 hubo otro, el de 1943, que le puso fin a la llamada "década infame", que había comenzado con el derrocamiento del presidente Yrigoyen, en 1930. La década infame se caracterizó por la corrupción y el fraude en lo que se refiere a la política interior y a una cierta neutralidad en relación a la política externa. Asume, entonces, la conducción del país un gobierno militar de facto que, para llevar a cabo el golpe, había logrado unir a nacionalistas y pro-aliados, "germanófilos" y liberales apoyados por radicales (del partido Unión Cívica Radical) y conservadores, o sea apoyados por una parte de la sociedad civil.

Al frente de la Secretaría del Ministerio de Guerra se encontraba el coronel Perón ${ }^{8}$, quien se transformaría en presidente electo democráticamente, con amplio apoyo popular, a partir de 1946:

El coronel Juan Domingo Perón, uno de [los] miembros más destacados [del gobierno militar que asumió el poder el 4 de junio de 1943], logró concitar un vasto movimiento político en torno de su persona, que le permitió ganar las elecciones de febrero de 1946, poco después de que su apoyo popular se manifestara en una jornada por demás significativa, el 17 de octubre de 1945. Perón completó su periodo de seis años y fue reelecto en 1951, para ser derrocado por un golpe militar en septiembre de 1955. (ROMERO, 1994, p. 140)

El programa de gobierno de Perón era de corte industrialista, y su base de apoyo estaba en ciertos sectores industriales y en la clase trabajadora sindicalizada. Las medidas

\footnotetext{
7 "Directivas básicas del gobierno revolucionario", Buenos Aires, Presidencia de la Nación, s.d. En (ROUQUIÉ, 1998, p. 129).

${ }^{8}$ La bibliografía sobre el peronismo es vasta. Ver bibliografía la lista al final de este trabajo.
} 
sociales adoptadas — "se extendió el régimen de jubilaciones, de vacaciones pagadas, de accidentes de trabajo, se ajustaron las categorías ocupacionales y en general se equilibraron las relaciones entre obreros y patrones" (ROMERO, 1994, p. 143)condujeron a una amplia aceptación de su figura y de su gestión por los sectores populares. Pero también tomó medidas autoritarias — control de la tendencia política de los funcionarios civiles, afiliación obligatoria al Partido Peronista, control de los medios de comunicación, represión de la oposición-. La Unión Democrática ${ }^{9}$, coalición de partidos opositores, que había disputado las elecciones con Perón, organiza su discurso en torno al reclamo de una liberalización del régimen político.

En ese contexto, el primer intento de derrocar al gobierno peronista se produce en junio de 1955, un golpe violento y fallido que bombardea a civiles —partidarios del gobierno y curiosos - en Plaza de Mayo:

...El golpe no había tenido nada de los clásicos pronunciamientos, de los paseos militares pacíficos y declamatorios, sino que había presentado las características sangrientas y odiosas de la guerra civil: los rebeldes deben haber estado cegados por el odio para haber ametrallado civiles indefensos en la Plaza de Mayo y haberse ensañado con grupos de curiosos... (ROUQUIÉ, 1998, p. 109)

Finalmente, en septiembre de 1955, la "Revolución Libertadora" derroca al gobierno del general Perón. Llega, en apariencia, para "suprimir todos los vestigios de totalitarismo..." pero, en realidad, se trata de instrumentar una política económica que necesitaba redistribuir el ingreso nacional en perjuicio de la clase trabajadora que había sido beneficiada en los años anteriores. Las promesas de democratización no se cumplieron y de a poco se fueron promulgando medidas cada vez más represivas.

\footnotetext{
${ }^{9}$ Esta estaba conformada por radicales (de la Unión cívica radical), socialistas y comunistas. Los primeros ejercieron la oposición política entre 1946 y 1955; en el mismo período, la oposición ideológica partió de la izquierda socialista-liberal: "Aunque la crítica sin tregua que ésta formulaba al peronismo incluía también el cuestionamiento de la política económica del gobierno, el eje de la reprobación era de índole política, cultural y moral —dictadura, clericalismo, demagogia, aventurerismo, corrupción—." (ALTAMIRANO, 2001, p. 16).
} 
Para resistir a esas condiciones, se va formando la llamada "resistencia peronista". Dice Julio Troxler, uno de los sobrevivientes de la matanza que narra Operación masacre ${ }^{10}$ :

La resistencia comenzó en forma espontánea, sin organización centralizada. Fue una acción tendiente a oponerse, por todos los medios, a quienes detentaban el poder como consecuencia del golpe militar de setiembre de 1955. En cada lugar se emprendía la realización de panfletos, de pintadas y también de acciones violentas, todo acorde con la característica de cada compañero, dispuesto a encarar una u otra tarea. Era una forma de resistir a los usurpadores. No hubo tampoco conducción centralizada en ese momento, porque si bien es cierto que llegaron algunas cintas grabadas de Perón, éstas fueron difundidas en un ámbito muy reducido y la resistencia fue mucho más allá de ese ámbito. Lo que la define es precisamente su espontaneidad. Fue algo instintivo, de defensa. La gente, en su impotencia, sentía que había perdido algo, que se lo habían quitado por la fuerza. Estaba vivo, brutal, el recuerdo del 16 de Junio de 1955 y todos los hechos de barbarie entre los cuales el más inicuo fue el bombardeo indiscriminado del pueblo en Plaza de Mayo. (TROXLER, 1973) $)^{11}$

En ese contexto se llega al 9 de junio de 1956, fecha en la cual civiles y militares nacionalistas y peronistas, intentan retomar el gobierno. Fracasan y varios líderes son fusilados. Parte de la historia de esa jornada es la que narra Operación masacre.

\section{Resistencias ante un mundo que se derrumba ${ }^{12}$}

Rodolfo Walsh nace en 1927, en la provincia de Río Negro; sus padres eran de ascendencia irlandesa. Los primeros años de su educación primaria transcurren en una escuela de monjas, en la provincia de Buenos Aires y, a partir de 1937, debido a problemas económicos en la familia, es internado en un colegio irlandés para huérfanos y pobres. Después, hasta 1940, permanece como pupilo en otra institución de curas, también de irlandeses. Ya en esa época se dedica a escribir, principalmente sátiras sobre sus profesores; pero donde quedan registrados aquellos tiempos escolares es en sus

\footnotetext{
${ }^{10}$ Después fue asesinado, en Buenos Aires, el 20 de septiembre de 1974, por la Triple A (Alianza anticomunista argentina).

${ }^{11}$ Ver anexo.

12 Todas las informaciones sobre la vida de Rodolfo Walsh fueron extraídas de "Informe para una biografía" (LAFFORGUE, 2000, pp. 219-234) y "Rodolfo Walsh: cronología de su vida y obra" (BASCHETTI, 1994, pp.17-23).
} 
cuentos Irlandeses detrás de un gato (1966), Los oficios terrestres (1967) y Un oscuro día de justicia ${ }^{13}(1970)$.

En 1944 empieza a trabajar en la editorial Hachette, primero como corrector de pruebas, luego como traductor y finalmente como antólogo. A partir de los años '50 pasa a colaborar en diferentes publicaciones tanto con cuentos como con notas de divulgación cultural, o de interés general. En 1953 gana el premio municipal de la ciudad de Buenos Aires con Variaciones en rojo, un libro de relatos policiales, en los que predomina la influencia borgeana ${ }^{14}$.

En 1956 inicia la investigación que culminará con la publicación de Operación Masacre, en 1957. Al año siguiente publica como notas periodísticas lo que después se transformará, en 1973, en el Caso Satanowsky, "formidable alegato contra la corrupción en las entrañas del poder oficial" (LAFFORGUE, 2000, p. 228). Se trata del asesinato del Dr. Marcos Satanowsky, un prestigioso abogado que defendía los intereses de uno de los accionistas del diario La Razón, Ricardo Peralta Ramos. Un crimen que pasó meses sin ser resuelto, cuando todos los indicios apuntaban hacia las esferas oficiales.

En Cuentos para tahúres, recopilación póstuma de relatos escritos entre 1950 y 1961 , se pueden rastrear ciertos rasgos permanentes y algunos quiebres que marcan la escritura de Walsh, antes y después de Operación masacre.

Una primera constante, sin duda, es "el sueño eterno de justicia"15 oficial o, cuando esta falla, de los hombres. En relación a los cuentos anteriores al '56 (que, más próximos al policial de enigma, tienen como protagonistas a un periodista, Daniel Hernández, y a un comisario, cuyo nombre varía), Ángel Rama observa que "descansan sin decirlo sobre la confianza en la imparcialidad y eficacia de la justicia” (RAMA, 1994, p. 84), observación que se puede extender a la primera edición de Operación masacre.

En cuanto a las diferencias, se puede decir que si en los primeros textos la intervención de la policía y la resolución del enigma permiten reestablecer el orden perdido, o sea,

\footnotetext{
${ }^{13}$ Las referencias de las obras citadas en este apartado se encuentran en la bibliografía, al final de este trabajo.

${ }^{14}$ Varios críticos señalan la influencia borgeana en la obra inicial de Rodolfo Walsh. Ver, por ejemplo, "Las novelas policiales del pobre" (RAMA, 1994, pp. 79-86)

${ }^{15}$ Título de un artículo de Ana María Amar Sánchez (2000, pp. 205-216).
} 
reestablecer la vigencia de la ley, en los cuentos posteriores a Operación masacre (más próximos al policial negro, incluyen la saga del comisario Laurenzi) esto ya no ocurre. Walsh pasa de crear policías "simpáticos" (casi oprimidos por la sociedad) y asesinos "convictos", a crear policías y asesinos "angustiados", llenos de dudas y culpas. Hasta llegar al punto en el que, claramente, los culpables son los representantes de la ley el juez de "En defensa propia"- o de la clase dominante - el estanciero de "Los dos montones de tierra" ${ }^{\prime 16}$. En palabras de Roberto Ferro:

.... Ios culpables representan a la ley, y la víctima entra en la difusa bruma de la sospecha. Ya no hay posibilidad de una conclusión que suponga un retorno a un orden transgredido por el delito. (FERRO, 1997, pp. 207-219)

Este recorrido por la obra de Rodolfo Walsh nos puede dar una clave del significado que tuvo para la vida del autor haber investigado y escrito sobre los fusilamientos en el basural de José León Suárez. Antes de la realización de Operación masacre, en 1955, Walsh había escrito un artículo, "2-0-12 no vuelve", publicado en Leoplán —evista de variedades - sobre la intentona golpista contra Perón, en junio de 1956. Se trata de un texto en el cual el autor elogia la valentía de un aviador muerto durante dicha tentativa. Aunque Walsh se encuentre entre los intelectuales que vieron con buenos ojos el golpe cívico-militar de $1955^{17}$, pronto se sentirá desilusionado y hasta traicionado por la revolución "libertadora" al ver que esta no reconduce al estado de derecho; así, se opera en el autor una pérdida paulatina de la confianza en las Instituciones, en el Estado y, sobre todo, en la justicia oficial. En sus propias palabras:

Operación masacre cambió mi vida. Haciéndola comprendí que además de mis perplejidades íntimas, existía un amenazante mundo exterior. (WALSH, 1996, p. 12)

\footnotetext{
${ }^{16}$ Elena Bracera, Cristina Leytour y Susana Pittella levantan la hipótesis de que Walsh pasa de un primer momento "de respeto a las reglas del género y 'traducción' más fiel del original inglés" a una etapa posterior en la cual, porque se siente más seguro en relación al género, lo maneja más libremente. (BRACERAS, et. al., 2000, pp. 99-104). Considero que además de la familiarización con el género, lo que realmente se produce en Walsh es un cambio en la percepción de la realidad.

${ }_{17}$ El propio autor hace esta afirmación en el "Prólogo para la edición en libro (de la primera edición, julio de 1957)", (WALSH, 1998, p. 263).
} 
Entre 1959 y 1961 Walsh vive en Cuba, donde participa en la fundación de la agencia de noticias Prensa Latina ${ }^{18}$. Allí será, según Gabriel García Márquez (uno de sus compañeros en la agencia) "el hombre que se adelantó a la CIA": Walsh descifra un cable del jefe de dicho organismo en Guatemala con información sobre el entrenamiento de exiliados cubanos en ese país ${ }^{19}$. A su vuelta a Buenos Aires continúa escribiendo cuentos policiales y estrena un par de obras de teatro - "La granada y "La batalla"-, publica dos libros de cuentos — "Los oficios terrestres" (1966) y "Un kilo de oro" (1967)—, escribe textos que cruzan literatura y periodismo y participa como jurado en concursos literarios. También trabaja como anticuario y traductor, hasta que a partir de 1968 comienza a dirigir el semanario de la CGT de los Argentinos, órgano periodístico de la fracción más combativa del sindicalismo de aquel momento. En dicho semanario publica una serie de notas sobre la muerte "del simpático matón y capitalista de juego" Rosendo García, que después aparecerán publicadas en ¿Quién mató a Rosendo?.

\section{Tanto en Operación masacre, como en el Caso Satanowsky y ¿Quién mató a Rosendo?}

Walsh denuncia las prácticas criminales o corruptas de diferentes instancias del poder: en el primero, de la policía, el ejército y la justicia; en ¿Quién mató a Rosendo?, del sindicalismo burocrático (aliado a la dictadura de turno; en este caso, el gobierno del general Onganía) y de los medios de información "serios"; en el Caso Satanowsky, de los

\footnotetext{
18 'En su 'Prólogo' a Los que luchan y los que Iloran, e Jorge Ricardo Masetti, periodista argentino encargado por el gobierno cubano de organizar Prensa Latina, Walsh traza un vívido cuadro del trabajo inicial en esa agencia y de quienes lo realizaban" (LAFFORGUE, 2000, p. 228). Dicho prólogo también puede ser leído en Ese hombre y otros papeles personales (WALSH, 1996, pp. 103-112). Sobre Walsh, Masetti y Prensa Latina se puede encontrar información en Rodolfo Walsh en Cuba. Agencia Prensa Latina, militancia, ron y criptografía (ARROSAGARAY, 2004).

${ }_{19}$ En realidad fue Rodolfo Walsh quien descubrió desde muchos meses antes que los Estado Unidos estaban entrenando exiliados cubanos en Guatemala para invadir Cuba por Playa Girón en abril de 1961. Walsh era en esa época el jefe de Servicios Especiales de Prensa Latina, en la oficina central de La Habana. Su compatriota, Jorge Ricardo Masetti, que era el fundador y director de la agencia, había instalado una sala especial de teletipos para captar y luego analizar en juntas de redacción el material informativo de las agencias rivales. Una noche, por un accidente mecánico, Masetti se encontró en su oficina con un rollo de teletipo que no tenía noticias sino un mensaje muy largo en clave intrincada. Era en realidad un despacho de tráfico comercial de la "Tropical Cable" de Guatemala. Rodolfo Walsh, que por cierto repudiaba en secreto sus antiguos cuentos policiales, se empeñó en descifrar el mensaje con ayuda de unos manuales de criptografía recreativa que compró en una librería de lance de La Habana. Lo consiguió al cabo de muchas horas insomne sin haberlo hecho nunca y sin ningún entrenamiento en la materia, y lo que encontró dentro no fue sólo una noticia sensacional para un periodista militante, sino una información providencial para el gobierno revolucionario de Cuba. El cable estaba dirigido a Washington por el jefe de la CIA en Guatemala, adscripto al personal de la embajada de Estados Unidos en ese país y era un informe minucioso de los preparativos de un desembarco en Cuba por cuenta del gobierno norteamericano. Se revelaba, inclusive, el lugar donde empezaban a prepararse los reclutas... (GARCíA MÁRQUEZ, 1994, pp. 313-314)
} 
servicios de información de la Revolución Libertadora y, nuevamente, de los medios de información.

Sin embargo hay diferencias, entre Operación masacre y los otros dos textos, en lo que se refiere a la actitud del autor-narrador frente a su investigación y a su escritura. Mientras que en el primero, hay una resistencia a "entrar" en la historia, a abandonar la cómoda vida de periodista, de escritor, de jugador de ajedrez — “Valle no me interesa. Perón no me interesa, la revolución no me interesa. ¿Puedo volver al ajedrez?” (1998, p. 18)—; los otros dos están escritos desde la militancia política. Mientras que en Operación masacre el autor declara: "Escribí este libro para que fuese publicado, para que actuara" (1998, p. 255), y está dirigido a un público amplio; en ¿Quién mató a Rosendo? define a sus interlocutores de una manera más precisa: “...su tema profundo es el drama del sindicalismo peronista a partir de 1955, sus destinatarios naturales son los trabajadores de mi país" (1997, p. 7); en tanto que en el Caso Satanowsky, una recuperación en 1973 de las notas del '58, el narrador afirma:

Los mecanismos que la Libertadora estableció en los campos afines del periodismo y los Servicios de Informaciones - temas del libro- siguen vigentes [...] Denunciar esos mecanismos, preparar su destrucción, es tarea que corresponde a los trabajadores de prensa. (1997, p. 17)

Si el Walsh de 1957 se resiste ${ }^{20}$ a abandonar el cómodo lugar que le permite su creencia en la justicia oficial, el de 1973 — y hasta su muerte—, se resiste a abandonar la lucha en pro de un mundo más justo.

Entre 1970 y 1973, Rodolfo Walsh será miembro de las FAP (Fuerzas Armadas Peronistas $^{21}$ ) que, luego abandonará para entrar en la organización Montoneros ${ }^{22}$ con el $^{2}$

\footnotetext{
${ }^{20}$ Horacio González, al trazar algunos paralelos entre Vida del Chacho, Operación masacre y Facundo, dice que el "tema que está presente [en Operación masacre] es el de la abdicación personal de ciertos bienes estimados que un tiempo inclemente llama a abandonar [...].Walsh es de los llamados intelectuales "comprometidos" y realiza ese compromiso, pero "mantiene un halo literario que juega a declarar que lo que hizo, hubiera preferido no hacerlo". (GONZÁLEZ, 2002, pp. 131-132).

${ }^{21}$ Las FAP fueron creadas en 1968 "para la guerra de guerrillas rural y urbana, e incluían a militantes peronistas [...] así como a [...] ex seminaristas católicos radicales..." (GILLESPIE, 1998, p. 138).

${ }^{22}$ Guerrilla urbana de extracción peronista, fundada en 1968, que actuó sobre todo a principio de los '70. "Los Montoneros empezaron [una organización de guerrilla urbana], pero se convirtieron rápidamente en un movimiento radical nacionalista [de reivindicaciones nacionales y populares] que, cuando se le permitió movilizar abierta y legalmente el apoyo político, lo hizo de manera impresionante. Decenas y hasta
} 
grado de oficial segundo y el alias de "Esteban". También será fundador y redactor principal del diario de orientación montonera Noticias. A principios de 1976, Walsh "deja constancia por escrito de sus diferencias de concepción, tácticas y estrategia con la cúpula de Montoneros, en un último intento de cambiar el rumbo, que de seguir así, llevaba a una segura derrota. No es escuchado." (BASCHETTI, 1994, p. 22).

En septiembre de 1976, cuando el gobierno argentino está, otra vez, en manos de dictadores, en un enfrentamiento matan a su hija mayor, María Victoria, "Vicky ${ }^{23 ", ~ d e ~} 26$ años y militante montonera. Walsh escribe entonces la "Carta a Vicky" —dirigida a su propia hija, relata cómo se enteró de la noticia de su muerte y cómo se siente - y la "Carta a mis amigos" - en la que cuenta cómo murió Vicky_. En la primera, para hablar de su dolor, dice: "Hoy en el tren un hombre decía: 'Sufro mucho. Quisiera acostarme a dormir y despertarme dentro de un año'. Hablaba por él pero también por mí." En la segunda, transcribe el relato de uno de los conscriptos presentes en el combate en el que cae su hija.

Ricardo Piglia, al analizar ambas cartas, se refiere a un rasgo estilístico común a las dos, que consiste en un "desplazamiento" ${ }^{24}$ : Walsh le da la voz a otro que va a expresar todo su dolor. Si la pregunta móvil del testimonio es “¿cómo narrar el horror?” y se habla de una cierta imposibilidad de hacerlo, Walsh usa dicho recurso como forma de resistir a la limitación que le impone la palabra.

A pesar de la muerte de Vicky, Walsh no se rinde ${ }^{25}$. En junio de 1976, crea ANCLA (Agencia Clandestina de Noticias ${ }^{26}$ ) y, en diciembre, la Cadena Informativa "para romper el bloqueo de la información":

centenares de miles de argentinos se agruparon tras sus estandartes en los violentos meses de 1973-1974. (GILLESPIE, 1998, p. 13-14).

${ }_{23}^{3}$ La grafía del apodo de María Victoria varía según los autores, en cada caso sigo el original.

${ }^{24}$ Piglia, Ricardo. "Propuesta para el próximo milenio", en El Clarín digital, 03-02-2000. Piglia observa que Walsh usa el mismo rasgo de estilo en el prólogo a Operación masacre, cuando narra la muerte de un soldado bajo su ventana.

${ }^{25}$ Dice Horacio Verbitsky que "Desde la caída de su hija Vicki [...] Rodolfo supo que la capital era territorio sitiado que debía abandonar. La organización montoneros le ofrecía una pasaje a Roma, pero él buscaba en el mapa de la Provincia de Buenos Aires la ruta de las lagunas del sur para iniciar su parte en lo que describió como el repliegue de las masas 'hacia su propia historia, su propia cultura y su propia psicología'. Con falsa identidad [...] compró una casita [...]. Metódico empezó a desmalezar el terreno, cubierto de yuyos. En la tierra, que le daría los medios para subsistir, y en el simultáneo reencuentro con la escritura, buscaba otra forma de vida [...] Rodolfo estaba entusiasmado. Perseguía hormigueros con una estaca, 
Reproduzca esta información, hágala circular por los medios a su alcance: a mano, a máquina, a mimeógrafo, oralmente. Mande copias a sus amigos: nueve de cada diez las estarán esperando. Millones quieren ser informados. El Terror se basa en la incomunicación. Rompa el aislamiento. Vuelva a sentir la satisfacción moral de un acto de libertad. Derrote el terror. Haga circular esta información. ${ }^{27}$

A los 50 años, el 25 de marzo de 1977, Rodolfo Walsh cae en una emboscada. Ese mes, en el que se cumplía un año del golpe militar contra Isabel Perón, había escrito la "Carta abierta de un escritor a la Junta Militar" - a pesar del hecho constatado de que "su destinatario eliminaba oponentes, reemplazando la pluma por el asesinato, la espada por la capucha y la palabra por el silencio." (KORN, 98, p. 145) - y la había llevado a las redacciones de diarios y revistas, pero nadie quiso publicarla.

El 25 de marzo entre las 13.30 y las 16, en algún lugar de la ciudad de Buenos Aires, Walsh es secuestrado por un Grupo de Tareas de la temible Escuela de Mecánica de la Armada (ESMA) [...] Al resistirse, lo asesinan. Tenía 50 años.

Sobrevivientes del campo de concentración clandestino de la ESMA acercaron a Patricia Walsh [otra de sus hijas] una versión de lo sucedido, escuchada a los propios captores, quienes estaban contrariados por no haber podido secuestrar a Walsh con vida. Según esa versión, Rodolfo debía ser "tacleado" por el oficial de Marina y ex rugbier Alfredo Astiz, quien falló en su intento. Esto generó una momentánea confusión que permitió a Rodolfo gatillar el revólver de calibre 22 corto que guardaba en la entrepierna. Así hirió a uno de sus agresores, que quedó rengo. A fines de 1977, ese hombre fue galardonado con una medalla en una ceremonia secreta de la ESMA. (BASCHETTI, 1994, p. 23)

El nombre de Rodolfo Walsh forma parte de la larga lista de desaparecidos durante la última dictadura militar argentina.

cortaba el pasto con una guadaña, ordenaba carpetas y escribía. Había trocado el fusil de la guerra, que antes que nada reconoció perdida, por la máquina de escribir de la que brotaban sus cartas polémicas... (VERBITSKY, 2000, p. 25)

26 "De estructura artesanal y alimentada sobre la base de información popular, ANCLA funcionó como una herramienta política ofensiva en el marco de la resistencia a la última dictadura militar (1976-1983). [...] ANCLA nació en el marco de una situación represiva donde la censura y la autocensura de los medios estaba a la orden del día: justamente, entre alguno de los máximos objetivos de la junta de comandantes de las tres armas que tomó por asalto el poder, figuraba el amordazamiento de la prensa." La agencia dependía del Departamento de Informaciones e Inteligencia de Montoneros (VINELLI, 2000, p. 11 y 19).

${ }^{27}$ Extraído de "Rodolfo Walsh: cronología de su vida y obra" (BASCHETTI, 1994, p. 22) 


\section{CAPÍTULO 2: MODOS DE LEER OPERACIÓN MASACRE}

La bibliografía sobre Rodolfo Walsh y su obra - aparecida en diarios, revistas, libros, tesis, etc.- es extensa ${ }^{28}$; comienza en los años '50 y se prolonga hasta nuestros días. Sin embargo, hasta 1972 no existen estudios sistemáticos sobre el trabajo de Walsh. Jorge Lafforgue, en la presentación de Textos de y sobre Rodolfo Walsh, da un panorama sobre dicha situación:

...cuando Walsh publicó el grueso de su obra [en los años 60] se habló mucho de ella, se le hicieron algunos reportajes y aparecieron varias notas: autor y obra cobraron entonces notoriedad; pero recién en 1972 la extensa indagación de Aníbal Ford constituyó una crítica a la altura de su objeto: la escritura walshiana. (LAFFORGUE, 2000, p. III-IV)

También, en los años '70, los comentarios — "la exaltación (o el borramiento)" - se centraron en la figura del escritor militante o solo en la del militante. Sin duda, contribuyó con esa mirada el hecho de que Walsh, a partir de 1968, se entregara a dicha práctica y dejara de producir "escritura literaria"29.

Al restablecerse el sistema constitucional, en 1983, comienza a circular un texto de Ángel Rama, "Las novelas policiales del pobre", de 1974, y "los rescates de Horacio Verbitsky y Juan Sasturain, junto con las reediciones de los libros de Walsh [...] realimentan un campo que ganó incluso algunos espacios académicos" (LAFFORGUE, 2000, p. IV).

Cuando Operación masacre aparece por primera vez estaba llegando a su fin un período, iniciado casi al final de los años ' 30 , en el que la literatura latinoamericana se había abierto al proceso de transformación seguido por toda la literatura occidental "(en la línea de combate: Kafka, Joyce, Céline, Faulkner, Hemingway)"; y comenzaba un nuevo período en el que esa literatura gana "plena madurez expresiva" al incorporar nuevas

\footnotetext{
${ }^{28}$ En Textos de y sobre Rodolfo Walsh, organizado por Jorge Lafforgue, se halla la bibliografía más completa elaborada hasta hoy.

${ }^{29}$ Víctor Pesce, quien se refiere al "enmudecimiento" de Walsh, a "la no escritura literaria" desde 1968, y a su completa entrega a la militancia revolucionaria, nos recuerda sus declaraciones de 1973: "Hoy es imposible en la Argentina hacer literatura desvinculada de la política" (PESCE, 2000, p. 44).
} 
técnicas y procedimientos que le permitieron cierta independencia cultural ${ }^{30}$ (LAFFORGUE, 1972, p. 11-12).

En particular, en Argentina, durante las décadas de 1940 y 1950, la literatura también se verá influenciada tanto por la política externa como por la interna. En un contexto internacional marcado por la ascensión del fascismo y el nazismo, la derrota de la República española, el estallido de la Segunda Guerra Mundial y, en la Argentina, los nuevos fenómenos socio-políticos asociados al surgimiento del peronismo, se producen reformulaciones en las relaciones entre literatura, sociedad y política ${ }^{31}$. Entre 1943 y 1955 la experiencia peronista lleva consigo una modificación en las percepciones "sobre el rol del Estado, las relaciones entre el Estado y la sociedad, el papel de los partidos y de las instituciones políticas; el concepto mismo de lo que significaba ser un ciudadano y de cuál era su lugar en la sociedad" (SAÍTTA, 2004, p. 8).

Junto con los cambios económicos, políticos y sociales se dan transformaciones culturales profundas, particularmente en los modos de circulación y apropiación de la literatura: se expande el mercado editorial ${ }^{32}$; hay más trabajo para los escritores (como asesores literarios, directores de colección, correctores de pruebas); se lleva a cabo una intensa labor de traducción que permite incorporar otras literaturas; se destaca el papel del traductor; se editan colecciones dedicadas a géneros literarios de consumo masivo.

En ese contexto, en general, la literatura argentina se quiere autónoma del acontecer político y de la realidad social; apela al género fantástico y al policial, ambos alejados del realismo, de la novela psicológica y de la literatura social. Asimismo, es el período en que la literatura argentina pierde su "provincianismo". En este sentido, la producción de

\footnotetext{
${ }^{30}$ Las citas de este párrafo fueron extraídas de la introducción Nueva novela latinoamericana II. La narrativa argentina actual. Allí, también dice Jorge Lafforgue que producciones como "Pedro Páramo o Ficciones, El astillero o Rayuela, Cien años de soledad o La casa verde ya no son subsidiarias de ningún modelo consagrado sino que por el contrario crean sus propios espacios judicativos. Ahora los criterios de validez no corresponden a categorías extrapoladas sino que surgen de la legitimidad de un proceso autónomo, independiente." (LAFFORGUE, 1972, p. 12). Es necesario aclarar que por la fecha de publicación de la Nueva novela... la cita tiene que ser leída a la luz del debate intelectual sobre la dependencia que se producía en aquellos años.

31 Para una información más completa sobre este período de la literatura en Argentina, véase la "Introducción" a Historia crítica de la literatura argentina. El oficio se afirma (SAÍTTA, 2004, pp. 7-15).

32 “...la Guerra Civil Española incidió fuertemente en la vida literaria y editorial argentina pues numerosos editores y libreros republicanos exiliados en la Argentina dieron comienzo a un nuevo período en la industria editorial." (SAÍTTA, 2004, p. 8).
} 
Borges dialoga con las grandes líneas del acontecer literario mundial, sin perder una referencia local fundada sobre nuevas bases: "Ia confrontación entre lo nacional y lo extranjero, lo propio y lo ajeno, lo particular y lo universal; la apropiación y resignificación de la tradición literaria argentina; la tensión entre los modos de representación realista y vanguardista, entre otros" ${ }^{\prime 3}$ (SAÍTTA, 2004, p. 10).

A partir de 1955, después del golpe de Estado, el peronismo pasa a ser la materia del debate intelectual; en ensayos, en artículos, en estudios, políticos, económicos, culturales, históricos, se realizan "revisiones del pasado para encontrar [...] salidas a la compleja problemática nacional". Y la narrativa se suma al cambio incorporando la política y la historia como materiales literarios (SAÍTTA, 2004, p. 14).

En este contexto, en 1957, aparece la primera edición de Operación masacre. Las formas de leerla, a lo largo de los años, se ha ido modificando dependiendo de las circunstancias históricas. Dice Roberto Ferro que las primeras publicaciones parciales en semanarios e inclusive la primera edición en libro fueron leídas como noticia periodística; el conjunto de estrategias que diseñan la trama no era novedoso para los medios gráficos. En "Las ediciones de 'Operación Masacre', señala el crítico que, en 1957

La puesta en relato de las acciones no aparece como un recurso novedoso en la tradición de los medios masivos (Crítica) [sic]. El suspenso y las detenciones en la narración, la vecindad del periodista que investiga y el detective, la presentación de indicios y el diferimiento, aparecen como 'naturales' en una estructura por entregas, determinada tanto por la periodicidad de las publicaciones como por la propia investigación que eran a menudo paralelas.

O.M. no es leída desde otro juego de lenguaje que no sea el periodístico ${ }^{34}$. (FERRO, 1988a, p. 65)

\footnotetext{
${ }^{33}$ Sobre la tensión entre cosmopolitismo y nación, véanse Una modernidad periférica: Buenos Aires, 1920 y 1930 (SARLO, 1988) y Vanguardias Latino-americanas. Polêmicas, manifestos e textos críticos (Schwartz, 1995).

34 A pesar de esta afirmación, no parece ser lo que se desprende de un reportaje a Rodolfo Walsh, "Les presentamos a R. J. Walsh", aparecido en la revista Mayoría, en 1958. Allí, en la presentación, el periodista Juan Bautista Brun relata el momento en que Walsh ofrece los originales de Operación masacre a la revista Mayoría:
}

—Traigo algo que puede ser interesante — nos dice-. Sé que usted tiene vinculaciones estrechas con el director de Mayoría y quiero ofrecerle esto.

"Esto" era una serie de artículos, con algunas fotografías, bajo el rótulo común de Operación masacre. (BRUN, 1994, pp. 142-143) [el subrayado es mío] 
En los años '60, Rodolfo Walsh publica la mayor parte de su producción literaria ${ }^{35}$ además de que salen la segunda y tercera ediciones de Operación masacre $(1964,1969)$.

Es un tiempo marcado por una ebullición de la crítica -en particular, en la política y en el arte- estimuladas por varias causas ${ }^{36}$ : en el plano intelectual, entre otros aspectos, por las reflexiones sobre la Segunda Guerra y la emergencia de la filosofía existencialista. En la política externa, por un lado, la creciente importancia de países del Tercer Mundo, los procesos de descolonización y las guerras antiimperialistas (Argelia, Vietnam); por otro, en el continente americano, los movimientos de reivindicación nacional con propuestas de desarrollo autónomo y rechazo a la dominación imperialista o movimientos más radicales para los cuales liberación nacional significa liberación social. Estamos en los tiempos de la Revolución Cubana y de la Guerra Fría y la preocupación política, en Argentina, trasciende lo nacional y se extiende al continente. En lo estrictamente local, a todo lo anterior hay que sumarle los cambios producidos a partir del gobierno peronista, que no solo significaron conquistas para la clase obrera sino también para los sectores medios: fundamentalmente, una coyuntura económica relativamente propicia y la extensión de derechos civiles (CELLA, 1999, pp. 8-9).

Se puede decir que los años que van entre 1955 y 1976 se caracterizan por un espíritu cuestionador de las distintas áreas del saber y de la sociedad. 'La palabra 'revolución' se convierte en una especie de símbolo, un condensado de creencias, teorías e imágenes

\footnotetext{
La indefinición genérica en relación a la forma de denominar el material, indicada por el "esto", se acentúa a lo largo de la entrevista en la cual, la mayor parte del tiempo parecería que se evita encuadrarlo como notas o artículo: "Anuncien en el próximo número la publicación de Operación masacre", "Usted reveló en Operación masacre...", “¿Qué pasó con la edición en libro de Operación masacre?”. La respuesta de Walsh a esta última pregunta creo que no deja dudas en cuanto a la intuición del autor de que "esto" podía ser leído como literario:
}

Se publicó a fines del año pasado y se agotó rápidamente. De los diez diarios que ya editan en Buenos Aires, y que tienen crónica literaria, ni uno solo le dedicó un par de líneas... (BRUN, 1994, p. 149) [el subrayado es mío]

Es decir, puede ser que para la gran mayoría de los lectores, Operación masacre representase un conjunto de notas periodísticas, pero sin duda no es la visión de Walsh, en aquel momento.

${ }^{35}$ Los oficios terrestres y La granada. La batalla son de 1965; Un kilo de oro, de 1967 y ¿Quién mató a Rosendo?, de 1969.

${ }^{36}$ Para una información más completa sobre la producción literaria del período 1955 a 1976, véase Historia crítica de la literatura argentina. La irrupción de la crítica, en particular la "Introducción", (CELLA, 1999, pp. 7-16). 
que impregna todos los debates." Entre ellos los que dicen respecto a la relación entre literatura y revolución incluyen dicotomías tales como:

...autonomía literaria versus función social y revolucionaria de la literatura; estrategias formales y experimentación o privilegio de los aspectos comunicativos; literatura de la revolución o revolución en la literatura; escritor comprometido o escritor aliado al sistema de dominación; poetas terrestres 0 poetas celestes... (CELLA, 1999, p. 10)

Se critica "la idea de literatura como pura comunicación —explícita, sin ambigüedades, directa, didáctica - de postulados sociales y políticos". Se rechaza y condena cualquier tipo de neutralidad o distanciamiento respecto de los hechos del presente: "el presente es el tema y es el punto de partida de toda reflexión, de toda acción"; se desmitifica el pasado: la crítica "pone en entredicho el modo en que ese pasado ha sido organizado y estatuido" (CELLA, 1999, pp. 9-10).

Las formas de leer Operación masacre, en los '60, son influenciadas por este contexto social, cultural y político. Roberto Ferro (1988a) señala que, si bien en 1964 ya comienza a hacerse una lectura literaria del texto de Walsh — guiada, fundamentalmente, por la distancia temporal en relación con los sucesos narrados y por su reescritura-, es a partir de 1969 que Operación masacre "se lee alternativamente como testimonio político, o como relato literario o ensayo sociohistórico entre otras variantes intermedias". Además, dice Ferro que, si la posibilidad de lectura literaria se abre debido al creciente interés en la novela negra y la no-ficción, también

Leer O.M. desde la literatura a principio de los años 70 se articula a la posibilidad de transformar la individualidad del acontecimiento constituido por el ensayo sociohistórico o el testimonio periodístico de [sic] una significación más amplia afín a la tradición aristotélica: el historiador y el poeta difieren en el hecho de que uno narra lo que sucedió y el otro lo que pueda suceder. (FERRO, 1988a, p. 66)

Es decir, de una lectura en la que, aparentemente, prevalece lo periodístico, en 1957, se comienza a privilegiar la otra, la literaria, a partir de los '70. Después de 1974 pasan diez años, dictadura de por medio (dice Ferro -1988a, p. 66-: "Esa es también otra lectura, la que hace la Dictadura Militar"), hasta que se vuelve a editar Operación masacre. 
A partir de los años ' 80 y, especialmente, de los '90, Operación masacre es considerada como una obra testimonial en la cual se producen cruces o desplazamientos de otros géneros, especialmente el periodístico y el policial (RAMA, 1983), (MAYER, ROGERS, CRESPO, 1998), (ALABARCES, PESCE, AGUILAR, 2000). Romano (2000), que comenta los modelos y géneros presentes en la obra inicial de Rodolfo Walsh (desde la periodística y Variaciones en Rojo hasta Operación masacre), también considera el género policial. Braceras, Leytour y Pittella (2000) sostienen que Walsh va de una etapa inicial de respeto a las reglas del género policial clásico, el inglés, hasta constituirse en un "escritor de cuentos policiales argentinos" (p. 99).

Amar Sánchez (2000) y García (2004) consideran el cruce entre no-ficción (o testimonio) y lo policial. Rita de Grandis (2000) identifica y diferencia tres registros: el de la historia, la crónica periodística y la ficción realista. Entre los comentadores que analizan la forma argumentativa de Operación masacre, como es el caso de Crespo y Pampillo y Urtasun (2000), se encuentra también Ferro (2000), quien considera el modelo de la obra como una oratio judicial.

Tanto Piglia (2000) como Pesce (2000) destacan la tensión entre literatura y política. Dice el primero que la obra de Walsh está marcada por la escisión de dicha relación. Pesce, por su lado, llama la atención sobre la necesidad de mantener tal tensión irresuelta; contra las lecturas que, concentrándose solo en la parte periodística o testimonial de la obra de Walsh tienden a ver resuelta la tensión entre literatura y política, destaca la importancia de considerar la obra walshiana en su totalidad ${ }^{37}$.

\footnotetext{
37 "Ella enuncia [la opinión] —al hacer hincapié en la obra llamada periodística o testimonial—, que Rodolfo Jorge Walsh sería el paradigmático producto de una tensión resuelta: la establecida entre el intelectual y la política. O mejor, entre el escritor de ficciones (lo lúdico) y la urgente responsabilidad de una política revolucionaria (el compromiso)" (PESCE, 2000, p. 43). Para Pesce, Walsh trabajó en el interior de dicha tensión, entre literatura y política, pero no la resolvió; todo lo contrario: "Su valor [el de la obra] habita en el entrecruzamiento que produce dicha tensión, en sus deslizamientos de géneros consagrados, en sus mezclas pioneras en muchos aspectos..." (p. 51). Pesce evalúa que esa opinión (la de que Walsh "resolvió") viene de "Un mal entendido de los 80 y principios de los 90, [que] caricaturiza y degrada el new journalism y las non fiction de los 60", al apresurarse a dar por resuelta una cuestión, en un contexto audiovisual, que "presenta como saldada una polémica que fue una de las tantas cuestiones interrumpidas por el golpe militar de 1976." (p. 44).
} 
Los críticos que abordan la cuestión de la filiación literaria o la tradición en la que se insertaría Walsh coinciden en resaltar el peso de la influencia borgeana (FORD, 1972), (RAMA, 1983), (CRESPO, 1998), (ALABARCES, PESCE, ROMANO, 2000). Tanto para Alabarces como para Pesce la escritura de Borges no es la única influencia, también lo es el periodismo; éste representaría el campo de la práctica, mientras que la escritura literaria sería el campo de la reflexión teórica. David Viñas (1996) se refiere a Operación masacre como testimonio fundamental que se inscribe en la tradición inaugurada con José Hernández y prolongada en Roberto Arlt ${ }^{38}$. Horacio González (2002), por su parte, también vincula Vida del Chacho y Operación masacre: "son libros fundadores de la historia criminal de la nación"39. En el mismo artículo, González establece otra comparación, esta vez con el Facundo de Sarmiento: en ambos, Operación... y Facundo, "hay un contraste entre lo que se elige abruptamente y la nostalgia por lo que se abandona" $^{40}$ (p. 132).

El rasgo estilístico que la mayor parte de los críticos destaca es el que denominan, en general, "dialogismo"; aunque Romano (2000) habla de perspectivismo, es decir, las múltiples voces presentes en Operación masacre. Mayer (1998) se refiere a la "desigualdad de las voces": como el espacio de la narración está habitado por las voces, los cadáveres y los procesos jurídicos, las "resonancias de la palabra de las víctimas no se igualan a las de los victimarios" (1998, p. 9). Ricardo Piglia (2000a), por su parte, se

\footnotetext{
38 José Hernández "comenta" el degüello del Chacho Peñaloza, en 1863; Roberto Arlt describe el fusilamiento Severino Di Giovanni, en 1931. "Estos momentos portan tres blasones [el otro es Operación masacre] que corroboran las complejas y mediadas, pero decisivas relaciones entre la política argentina y el espacio textual: la liquidación del gaucho rebelde, la eliminación del inmigrante peligroso y la masacre del obrero subversivo. La carta abierta de Walsh a la dictadura de 1977 -al inscribirse en esa secuencia como cuarto blasón- no sólo la continúa y ahonda sino que preanuncia ya el asesinato del intelectual heterodoxo" (VIÑAS, 1996, p. 215).

39 "Vida del Chacho tiene una característica que lo acerca a ciertas modalidades de la investigación de los crímenes del Estado realizados [sic] por particulares o periodistas independientes que ejerciendo una fiscalía heroica [...] denuncian a riesgo de vida un horrible delito encubierto desde el mundo oficial" (GONZÁLEZ, 2002, p. 129).

${ }^{40}$ En el caso de Sarmiento, "Io que se elige es escribir el Facundo como una misión política, ganado por una urgencia ostensible y un llamado al combate. También aquí se asume la fuerza retórica de lo que no hubiera preferido hacerse y sin embargo se hace". Recordemos que es el mismo caso de Walsh, en Operación masacre, cuando manifiesta su deseo de "volver al ajedrez". González dice que se trata de un "halo literario": "...Walsh, tan tajante y contundente en sus opciones morales, mantiene un halo literario que juega a declarar que lo que hizo, hubiera preferido no hacerlo" (p. 132).
} 
refiere a un "desplazamiento" y "toma de distancia" en el que el otro "dice" el propio dolor del autor ${ }^{41}$.

Entre el conjunto de los textos críticos referidos a Operación masacre quisiera destacar tres, que corresponden a tres formas diferentes de leer esta obra de Walsh. Uno de ellos es el ya clásico artículo de Aníbal Ford (1972), "Walsh: la reconstrucción de los hechos", en el cual la identificación de ficción e invención conduce al autor a negar el estatuto literario de Operación masacre.

\section{Literatura no ficcional}

En "Walsh: la reconstrucción de los hechos" (1972), Aníbal Ford lee la obra de Rodolfo Walsh a la luz de la experiencia de vida de su autor; éste, al reconstruir los hechos, los estaría analizando y la reflexión lo llevaría a descubrir la realidad objetiva:

Esto y no una problematización estética (los problemas del tipo planteado por preguntas como ¿qué o cómo debo escribir?) es lo que hace evolucionar su literatura. Es decir, ésta cambia porque cambia quien la hace y no porque se haga una nueva elección en un campo específico. (p. 317)

Ford se guía por la premisa de que la literatura es "algo que se hace en la historia y no fuera de ella", lo que lo lleva a afirmar que "la obra de Walsh, aparentemente sin mundo literario propio, se organizó a través de la exploración biográfica” (pp. 317-318). Esta afirmación es construida a partir de la conocida declaración del propio autor: "Operación masacre cambió mi vida. Haciéndola, comprendí que, además de mis perplejidades íntimas, existía un amenazante mundo exterior".

Esa mirada de la obra a través de la vida de su autor, hace que Ford interprete que la forma de presentar los hechos en Operación masacre, Caso Satanowsky y ¿Quién mató a Rosendo? se deba a la manera que Walsh tiene de reflexionar sobre la realidad más que

\footnotetext{
${ }^{41}$ Específicamente, en Operación masacre se refiere al soldado que Walsh escucha morir bajo su ventana, el día de la Revolución de Valle.
} 
a su experiencia como escritor de literatura policial o a una búsqueda de novelar. Por eso, "los cortes en la lectura y mecanismos de suspenso" provienen del hecho de que los textos son investigaciones en curso, en las que Walsh mantiene una especie de diálogo con los implicados, en los que se dan oportunidades o se presiona (pp. 290-291).

O sea, en 1972, y en el primer estudio sistemático de la obra de Walsh, se le niega a los tres textos el carácter ficcional. Se pueden leer como literatura, siempre y cuando ésta se considere diferente de la ficción y se entiendan los guiños literarios como una búsqueda de mayor efectividad en la tarea de denuncia que se ha propuesto el autor; también se pueden aceptar como merodeos para comprender, para reflexionar sobre "la injusticia, el miedo, la prepotencia, la explotación, el desamparo [...] una forma de hablar de Argentina sin enajenaciones metodológicas" (FORD, 1972, p. 291).

\section{Ficción policial}

Una segunda tendencia en la lectura de Operación masacre se caracteriza por filiarla a la ficción policial, y tiene por antecedente el también ya clásico artículo de Ángel Rama ${ }^{42}$ "Las novelas policiales del pobre", que comienza a circular en Argentina después de la última dictadura militar (1976-1983). En dicho artículo, escrito en 1974, Rama afirma que la obra está construida sobre el modelo del género policial, pero se trata de una novela policial para pobres:

...cualquiera de estos libros conservará igual validez, al margen de su correspondencia con hechos reales, y aun alcanzará la intensidad y el suspenso de una excelente novela policial. No se equivocará [el lector] en esta percepción, porque efectivamente están construidos sobre el modelo del género, salvo que se trata de novelas policiales para pobres. (pp. 227-228)

\footnotetext{
42 Ángel Rama, crítico uruguayo, era integrante del jurado de Casa de las Américas, cuando se decidió instituir el Premio Testimonio. Refiriéndose a dicha decisión, señala el crítico: "En enero de 1969, al concluir las deliberaciones de los jurados del premio Casa de las Américas, propuse en su reunión conjunta la institución de una nueva categoría a la que designaba con la palabra "Testimonio" [...] La proposición buscaba preservar la especificidad artística de la narrativa que en períodos de máximo interés político puede ser preterida, pero sobre todo apuntaba a un conjunto de libros que crecen día a día y que situados aparentemente en los lindes de la literatura, son remitidos a la sociología [...] y sobre todo al periodismo (como era en aquel momento el libro de Rodolfo Walsh Operación masacre, como sería dentro de otra orientación Las venas abiertas de América Latina de Eduardo Galeano)" (RAMA, 1983, p. 220).
} 
Los tres libros giran alrededor de hechos que primero aparecieron en la prensa, que tienen en común "un trasfondo sociopolítico que se trató de escamotear": en Operación masacre, el fusilamiento de trabajadores; en Caso Satanowky, el asesinato de un abogado judío argentino a manos de la Inteligencia Militar, crimen que tanto la prensa como los asesinos quisieron hacer pasar como racial; en ¿Quién mató a Rosendo? otra vez se trata del asesinato de trabajadores. O sea, los tres tienen en común un crimen del Estado protagonizado por u ordenado por las Fuerzas Armadas, un trasfondo políticosocial oscuro y "una opción de lector que predetermina los instrumentos, el lenguaje, las formas literarias empleadas" (p. 228). Pero, se distinguen del modelo policial tradicional fundamentalmente por una visión de mundo diferente. Walsh viene de las formas de la novela policial anglosajona, "que descansan [...] sobre la confianza en la imparcialidad y eficacia de la justicia"; y desemboca en los "dramas policiales ${ }^{43 "}$ que, en general, tratan "de la lucha contra la venalidad judicial" (p. 229).

Pero también la visión de mundo es diferente de la de los maestros ${ }^{44}$, los "modernizadores". Si para estos, la injusticia era global, "un caos instituido por dioses torpes, de una arbitrariedad esencial a la existencia humana" (p. 229), ahora se la identifica claramente con los aparatos de poder y tribunales, y se ejerce "sobre una [...] determinada población para servir a fines racionalmente comprensibles" (p. 230).

Tal vez, para entender el hecho de que Ángel Rama hable de "novela policial para pobres" y de una injusticia con "fines racionalmente comprensibles" hay que recordar el contexto político en el cual fue escrito este artículo, en 1974, tiempo de sueños en que todavía, para la izquierda latinoamericana, la utopía era posible. Dice el autor, en nota a pie de

\footnotetext{
43 "Dramas policiales" son un tipo de producción literaria proveniente de la cultura popular, que está relacionada con el folletín, y que tiene como modelo, en Latinoamérica, las novelas de Eduardo Gutiérrez (1851-1889), como Juan Moreira, en las cuales siempre se encuentran dos secuencias: "la correspondiente a la vida y los crímenes del protagonista y la que narra persecuciones a causa de la injusticia de tribunales y leyes..." (RAMA, 1983, p. 229).

${ }^{44}$ Dice Ángel Rama que, a pesar de excelente narrador, Walsh es más conocido por los reportajes periodísticos (en ese momento, Operación masacre había llegado a la novena edición) "que por su obra estrictamente literaria", sin embargo, "su tarea periodística es sin duda obra de escritor que supo aprovechar la lección de sus mayores.", en particular, la de Borges: “...de quien se le podría considerar un descendiente heterodoxo, porque si bien sus ideas políticas y sus concepciones del mundo son diametralmente opuestas, de él ha recibido Walsh esa lección de rigor [...] y sobre todo la inclinación por las formas literarias y los géneros narrativos de la 'modernidad'." (pp. 225-226).
} 
página, en el artículo "Rodolfo Walsh: la narrativa en el conflicto de las culturas" (o del cual forma parte el texto que estoy comentando):

Este ensayo fue escrito en 1974, atendiendo a las entonces recientes circunstancias políticas argentinas [...]. Los sucesos posteriores [ascensión de la derecha y sus consecuencias] son incidentes del mismo proceso en uno de sus períodos regresivos, sólo diferente en grado respecto a otros similares momentos de regresión, en que también el ejército entró a contener los intentos de modificación de la estructura económica y social del país. ${ }^{45}$ (p. 195)

\section{No-ficción y policial}

Una tercera tendencia entre las lecturas e interpretaciones de Operación masacre introduce su vinculación con el testimonio y la literatura testimonial. El primer trabajo en que se establece dicha relación es "La propuesta de una escritura (En homenaje a Rodolfo Walsh)", de 1986, de Ana María Amar Sánchez. En "El sueño eterno de justicia", artículo de 2000, la autora retoma y resume sus reflexiones ya publicadas anteriormente ${ }^{46}$.

Amar Sánchez considera Operación masacre, Caso Satanowsky y ¿Quién mató a Rosendo? como pertenecientes a la no-ficción, pero, aclara que usa esa denominación porque es así como se la conoce en la tradición ${ }^{47}$ y explicita lo que ella considera que son las características fundamentales del género. Para la autora, lo específico del género es

\footnotetext{
${ }^{45}$ Para mayor claridad, transcribo la nota completa: "Este ensayo fue escrito en 1974, atendiendo a las entonces recientes circunstancias políticas argentinas: retiro del militarismo después de siete años de ejercicio del poder, elecciones que consagraron a Héctor Cámpora y legal traslación a este de la presidencia por parte del general Lanusse, posterior renuncia de Cámpora y elección de Juan Domingo Perón con el $61,8 \%$ de los votantes, triunfo del peronismo a pesar de sus primeras escisiones internas, visibles desde los sucesos de Ezeiza a la llegada del dirigente exiliado. Los sucesos posteriores - muerte de Perón y ascensión a la presidencia de su esposa Isabel Martínez, conducción derechista a cargo de López Rega, crisis económica, acción de la guerrilla montonera y la del ERP, golpe de estado del ejército en marzo de 1976 con el ascenso del general Videla a la presidencia, represión de la insurgencia y del gremialismo, política económica fondomonetarista - son incidentes del mismo proceso en uno de sus períodos regresivos, sólo diferente en grado respecto a otros similares momentos de regresión, en que también el ejército entró a contener los intentos de modificación de la estructura económica y social del país" (p. 195).

${ }^{46}$ El relato de los hechos. Rodolfo Walsh: testimonio y escritura (AMAR SÁNCHEZ, 1992) y "La propuesta de una escritura (en homenaje a Rodolfo Walsh)"; éste último se puede leer en Rodolfo Walsh, vivo (AMAR SÁNCHEZ, 1994).

47 "Se mantiene el nombre de no-ficción — dice — para el género por razones de convención, ya que su uso se ha generalizado, aunque sobre la denominación relato de no-ficción pesa el implícito prejuicio de que todo relato 'normal' debe ser de ficción. De acuerdo a la hipótesis de este trabajo es más adecuado el de relato documental o testimonial" (AMAR SÁNCHEZ, 2000, p. 215).
} 
el modo en que resuelve la tensión entre lo testimonial y lo ficcional; tensión que se establece porque

El género se juega en el cruce de dos imposibilidades: la de mostrarse como una ficción, puesto que los hechos ocurrieron y el lector lo sabe, y la de ser un espejo fiel de los hechos. (2000, p. 205)

Para resolver dicha tensión, es importante el concepto de "construcción", pues el relato construye una versión del acontecimiento mediante "selección y montaje del material y los códigos narrativos que fusionan" (2000, p. 205). Estos recursos determinan, dice, una diferencia crucial entre la no-ficción y las formas de periodismo convencionales. Mientras que para estas últimas la verdad es un dato externo al discurso y, por eso, "cree dar cuenta objetivamente de ella"; para la no-ficción, "en cambio, se trata de un resultado, de una construcción discursiva producida por los sujetos” (2000, p. 208-209).

Además, otros rasgos de diferenciación entre la no-ficción y el género periodístico son, para la autora, la narrativización ${ }^{48}$ de los sucesos y el hecho de que en la no-ficción estará presente algún otro género que sea dominante en la producción del autor ${ }^{49}$ :

Parece indispensable para el género esta contaminación de códigos: narrar es crucial para diferenciarse del periodismo y son los procedimientos que se encuentran en la ficción (y en otro género) los que hacen posible este proceso. (p. 208)

\footnotetext{
${ }^{48}$ Quiere decir que el relato testimonial "construye una narración y lleva a primer plano [...] a aquellos sujetos que en una nota periodística quedarían en el anonimato. [...] La narración testimonial trabaja con dos procedimientos interrelacionados: la expansión de la historia y la concentración en el detalle. Expande y desarrolla la información periodística; pero esta ampliación, a su vez, se concentra en pormenores, focaliza pequeños episodios y convierte en 'personajes' a los sujetos que permanecen desdibujados en las notas de la prensa" (2000, pp. 207-208).

49 En El relato de los hechos, Amar Sánchez señala que "En la producción testimonial de Elena Poniatowska puede verse el uso de los medios de reproducción y de las técnicas periodísticas..." (1992, p. 55); en el caso de Jorge Semprún señala, como encuentro de varios códigos, el testimonial y el novelístico autobiográfico.
} 
En el caso de Rodolfo Walsh los géneros dominantes serían el policial y el periodístico. La no-ficción, el policial y el periodístico tienen en común, en sus fundamentos, la búsqueda de la verdad.

Lo que diferenciaría los textos testimoniales de Walsh de los relatos policiales clásicos sería la forma en que se considera la asociación entre delito, verdad y justicia. El objeto de Operación masacre, Caso Satanowsky y ¿Quién mató a Rosendo? es descubrir al culpable y que se haga justicia. Pero como la justicia no llega, se constata una progresión en la descreencia sobre la posibilidad de reparación de los crímenes ${ }^{50}$; esto le permite a Amar Sánchez filiar los tres textos no ficcionales a la novela policial dura, en la cual "subyace la conciencia de la imposibilidad del triunfo de la verdad en un sistema básicamente injusto" (p. 209). Si en el policial clásico se restablece la justicia, eso no sucede en el testimonio: "los textos no-ficcionales plantean de modo radical la imposibilidad de la justicia" (2000, p. 209).

Otra modificación esencial entre los textos de no-ficción y el género policial clásico es el hecho de que es el Estado el que comete el crimen; ahora la justicia es el delincuente, lo que transforma a la víctima en el acusado. En esta inversión de roles, la autoridad y la ley pasarán a quien se oponga al Estado criminal; en este caso, al narrador:

Este sujeto narra y toma posición acerca de los hechos; al hacerlo, funde los restos de dos géneros y construye un relato, una verdad y alguna clase de justicia. Porque han podido ser contados, los crímenes no han quedado del todo impunes: contar, narrar, es una manera de reparar. [...] los tres relatos noficcionales [...] reafirman el poder de la escritura; un poder que asegura la perduración —una forma de imponer la verdad y de hacer justicia — para evitar el olvido, es decir, para triunfar sobre la muerte. (p. 215)

\footnotetext{
${ }^{50}$ La autora da como ejemplos un fragmento de Operación masacre, del epílogo de 1964, y otro de la conclusión de ¿Quién mató a Rosendo?. En el primero se lee: “...investigué y escribí otra historia oculta, la del Caso Satanowsky. Fue más ruidosa, pero el resultado fue el mismo: las muertos bien muertos, y los asesinos probados, pero sueltos [...] Se comprenderá que haya perdido algunas ilusiones, la ilusión en la justicia [...]; en el segundo: "Hace años, al tratar casos similares, confié en que algún género de sanción caería sobre los culpables [...] Era una ingenuidad en la que hoy no incurriré [...] El sistema no castiga a sus hombres: los premia." (p. 209).
} 
Estas últimas afirmaciones de Amar Sánchez, ciertas en las intenciones de los autores del testimonio y quizás alguna vez posibles en lo que se refiere a determinados efectos "externos" 51 , me parecen problemáticas, primero, porque tienen el optimismo del deseo que no parece tener en cuenta que por mucho que se haya escrito y denunciado la violencia y la muerte, éstas persisten (y no por eso hay que dejar de escribir). En segundo lugar, considero que Operación masacre reconoce con crudeza la impotencia y la imposibilidad: los crímenes quedaron impunes, y lo no reparado está en la propia forma del texto.

De este panorama de la crítica que he sumariamente presentado, surge que, cuando se le reconoce a Operación masacre su carácter ficcional (lectura que no es hegemónica, como he intentado mostrar al comentar la interpretación de Ford), este reconocimiento va de la mano de su inclusión dentro del género policial. Según creo, éstas lecturas resultan insuficientes para dar cuenta de la complejidad de los mecanismos y las tensiones involucradas en la composición de la obra, como la búsqueda desesperada de una forma adecuada para relatar ciertos acontecimientos cuya violencia los vuelve esquivos a la representación.

\footnotetext{
${ }^{51}$ Pienso en la posible anulación de las leyes de Obediencia Debida y Punto Final (leyes de impunidad), que en estos días está siendo tramitada en la Corte Suprema de Justicia argentina, sancionadas por el Congreso en 1986 y 1987.
} 


\section{CAPÍTULO 3: PALABRAS Y RESISTENCIA}

Operación masacre es un texto que el autor construye y reconstruye a lo largo de quince años: antes de tomar forma de libro, Walsh publica seis artículos en un periódico independiente, Revolución Nacional; y la primera edición también sale, al principio, en una revista, Mayoría. Luego habrá cuatro ediciones en libro —1957, 1964, 1969 y 1972 - en las cuales Walsh realiza cambios de diferentes órdenes: agrega o modifica información, rehace introducciones y/o prólogos, elimina párrafos enteros, oraciones y palabras.

La edición de Operación masacre (WALSH, 1998) ${ }^{52}$ que manejo ${ }^{53}$ abre con una dedicatoria "A Enriqueta Muñiz" (p. 13), la periodista junto a quien Rodolfo Walsh realizó la investigación que después se transformaría en Operación masacre. A seguir consta un epígrafe que cita palabras del Comisario Inspector Rodolfo Rodríguez Moreno (p. 15), el ejecutor material del fusilamiento. Le sigue un "Prólogo" (pp. 17-25) y "Agradecimientos" (p. 27). La parte central del texto se divide en "Primera parte - Las personas" (pp. 29-78), "Segunda parte - Los hechos" (pp. 79-176), "Tercera parte - La evidencia" (pp. 177-239) y un "Apéndice - Operación masacre en cine" (pp. 241-247), en el que se reproduce la secuencia final de la película filmada clandestinamente en 1971 por Jorge Cedrón, con guión del propio Walsh. En los "Anexos" hay prólogos, introducciones y epílogos de otras ediciones (pp. 249-300), a los cuales me referiré a medida que comente los cambios de Operación masacre a lo largo de los años.

Este trabajo es una reflexión que se concentra en el texto que consta en la "Edición definitiva" de Operación masacre ${ }^{54}$, teniendo en cuenta los anexos y algunos de los principales cambios en la secuencia narrativa. Para organizar el trabajo, a continuación

\footnotetext{
${ }^{52}$ Todo aquello que conste en la "Edición Definitiva" de Operación masacre (WALSH, 1998) será citado solo con los números de página que corresponden a la misma. Para lo que no está incluido allí, coloco año y letra, cuando es necesario, y número de página.

${ }^{53}$ A pesar de que en la edición que utilizo hay, al principio, una presentación de Osvaldo Bayer, "Rodolfo Walsh: tabú y mito" (1998, pp. 7-12); y una presentación de los anexos, cuya autoría no está indicada (pp. 251-254), la descripción que hago a continuación se refiere únicamente al texto de Rodolfo Walsh.

${ }^{54}$ En Textos de y sobre Rodolfo Walsh hay una extensa bibliografía (tal vez, la más completa hasta ahora), "Hacia una bibliografía de Rodolfo Walsh", preparada por Jorge Lafforgue. Allí se lee sobre la edición con la cual trabajo: "Operación masacre. [...] Planeta/Espejo de la Argentina, 1994; prólogo de Osvaldo Bayer; se presenta como "edición definitiva", con un extenso apéndice documental, pp. 241-300." (AA.VV., 2000) [el subrayado es mío]. La observación "se presenta como..." hace pensar que todavía puede haber alguna otra edición o, tal vez, que no había consenso entre los especialistas sobre el hecho de que esta edición sea la definitiva.
} 
hago una somera descripción de las modificaciones introducidas por el autor a lo largo del tiempo.

\section{Las ediciones}

La primera noticia que aparece sobre el fusilamiento es una denuncia judicial hecha por Juan Carlos Livraga, uno de los sobrevivientes, en diciembre de 1956: "El texto [...], sabemos hoy, se publicó por iniciativa de Rodolfo Walsh" en el periódico Propósitos ${ }^{55}$ (p. 251). Después, entre enero y marzo de 1957, aparecen seis artículos en una "hojita gremial", Revolución Naciona ${ }^{56}$; y entre mayo y diciembre del mismo año, cuando Walsh ya tenía lista la primera versión de Operación masacre y nadie quería publicarla, aparecen otras nueve notas en la revista Mayoría ${ }^{57}$. Aquí, lo que luego serán los capítulos de la primera edición se organizan en dos partes: la primera corresponde a la primera y segunda de la edición en libro: "Las personas" y "Los hechos"; la segunda, a "La evidencia" y "Obligado apéndice", que constituyen la tercera y cuarta partes de dicha edición (1957). La publicación en libro y las notas periodísticas de Mayoría se diferencian, esencialmente, en algunos títulos de cada sección, sobre todo los de la primera parte, "Las personas".

La primera edición en libro, Operación masacre. Un proceso que no ha sido clausurado, aparece en 1957, "Sin embargo, los desmentidos, réplicas, apéndices y corolarios a la investigación se prolongan hasta abril de 1958" (p. 252). Abren el texto una dedicatoria: "A Enriqueta Muñiz, periodista, con gratitud" $(1957, \text { p. } 7)^{58}$ y un epígrafe de T. S. Eliot ${ }^{59}$, que

\footnotetext{
${ }^{55}$ Periódico de izquierda, cuyo director era Leónidas Barletta, "quien conoce a Walsh (pues ha sido jurado del primer concurso de relatos policiales organizado por la revista Vea y Lea [...] en el que fuera premiado uno de sus cuentos." (FERRO, 2000, p. 144)

56 "'Órgano del Instituto de Cultura Obrera' agrupación [...] a la que pertenecían algunos activistas de la militancia sindical que no tenían inserción en las estructuras peronistas." (FERRO, 2000, pp. 148-149)

57 De las notas aparecidas en Revolución Nacional tuve acceso a la primera, "Yo también fui fusilado" (WALSH, 1957), en el CeDInCi (Centro de documentación e investigación de la cultura de izquierdas en Argentina). Asimismo, en la Biblioteca Nacional en Buenos Aires, pude consultar y grabar en cinta casete ocho de las nueve notas aparecidas en Mayoría. Quiero hacer constar mi agradecimiento a la generosidad y amabilidad tanto de Horacio Tarcus y todos los colaboradores del CeDInCi, como de Roberto Baschetti, en la Biblioteca Nacional, a quienes llegué gracias a Jung Ha Kang y Eduardo Rinesi.

58 Para la segunda edición, Operación masacre y el expediente Livraga (1964), el autor modifica la dedicatoria, aunque continúa siendo a Enriqueta Muñiz; la nueva forma se mantendrá hasta la edición definitiva (p. 13)

${ }^{59}$ A rain of blood has blinded my eyes... and I wander in a land of // barren boughs: if I break them they bleed; I wander in a land of // dry stones: If I touch them they bleed. // How can I ever return to the soft quiet seasons? (1957, p. 8).
} 
a partir de la tercera edición será sustituido por palabras del "Comisario Inspector Rodolfo Rodríguez Moreno" (p. 15).

A continuación, en el texto de 1957 consta un "Prólogo para la edición en libro" (pp. 255256) y una "Introducción" (pp. 257-266). A partir de 1964 ambos serán substituidos por el "Prólogo de la segunda edición" que es el que se mantendrá, con una única modificación ${ }^{60}$, hasta la última edición.

Luego hay un corto agradecimiento a abogados, testigos e informantes, directores de los semanarios en los cuales aparecieron las sucesivas publicaciones de Operación masacre, sobrevivientes y familiares de las víctimas ${ }^{61}$. A partir de la segunda edición (1964), dicho agradecimiento, esencialmente dirigido a los mismos destinatarios, es mucho más extenso y explicativo, tal vez como una forma de tributo, para que no se pierdan en el tiempo ni en la memoria los nombres y actos de los involucrados. (p. 27)

Los cuarenta y cuatro capítulos siguientes se dividen en cuatro partes: "Las personas", "Los hechos", "La evidencia" y "Obligado apéndice". Aparte de algunas modificaciones internas (que serán comentadas oportunamente), la estructura de "Las personas" se mantiene la misma a lo largo de las diferentes ediciones: trece capítulos —ocho de ellos titulados con el nombre o apellido de las víctimas-. Allí el narrador construye "disciplinadamente" la rutina, el medio familiar, laboral y barrial de cada una de las personas; relata lo que hacían aquella noche del 9 de junio, desde algunas horas antes de la detención hasta el preciso momento de la llegada de la policía, hecho que imprime una ruptura en el día a día tanto de las personas, como en la forma de lo narrado.

En "Los hechos" hay alteraciones en algunos títulos y, a partir de la tercera edición (1969), se suprime el capítulo 23 , sin título ${ }^{62}$, "un paréntesis lírico e impostado, según confesara"

\footnotetext{
${ }^{60}$ En dicho prólogo se lee: "Es cosa de reirse [sic], a siete años de distancia..." (WALSH, 1964); y en el de la tercera edición dice: "Es cosa de reírse, a doce años de distancia..." (WALSH, 1969) [las cursivas son mías]. El registro del paso del tiempo entre la segunda y tercera ediciones ya no se hará en la cuarta (1972); allí sigue diciendo "a doce años", como una manera de dejar constancia que se está frente a una situación que ya no será modificada. Si en 1964 el autor todavía tenía alguna esperanza en la justicia, a partir de 1969 dichas esperanzas se han perdido y eso queda registrado en el prólogo.

61 "Agradecimientos: a los doctores Doglia y Von Kotsch, a M. a (sic) 'EAS', a 'ATILAS', a los directores de los semanarios independientes, a los sobrevivientes y a los familiares de las víctimas." (1957, p. 18)

${ }^{62}$ En Mayoría apareció como "Interludio" (WALSH, 1957 c)
} 
el propio Walsh (p. 252). El relato incluye desde la detención y el fusilamiento de las víctimas hasta que los sobrevivientes se ponen más o menos a salvo.

"La evidencia”, tercera parte de Operación masacre, está desarrollada en los capítulos 33 a 40 (1957, pp. 113-146). Aquí se vuelve sobre los hechos pero desde otro ángulo: contrastando la información oficial —declaraciones, informes, telegramas, etc. - con la obtenida por Walsh. En el capítulo 40, "Provisorio epílogo" (p. 289-293), el autor hace un balance personal de las tres revoluciones que se sucedieron en Argentina, entre 1955 y $1956^{63}$.

El "Obligado apéndice" (pp. 267-287) consta de cuatro capítulos, inspirados por la detención de Marcelo, uno de los implicados en el alzamiento de junio pero que no había sido detenido con las víctimas de la operación masacre.

A partir de la segunda edición, "La evidencia" y "Obligado apéndice" son substituidos por cuatro capítulos, prácticamente nuevos, bajo el título "La evidencia". El único que se mantiene de la primera edición, con algunas modificaciones, es el titulado "Fernández Suárez confiesa" y se incluyen "El expediente Livraga" —transcripción comentada de trechos de dicho expediente judicial—, "La justicia ciega" —que describe y comenta la suerte que corrió el proceso ante la justicia_y un "Epílogo".

Es el "Epílogo" el que ahora cambiará en las sucesivas ediciones: en la segunda, a siete años de la primera, el autor hace un balance de las ganancias y pérdidas con la investigación y la escritura del libro y termina preguntándose sobre la posibilidad de haberlo escrito mejor (pp. 295-298). A partir de la tercera, el "Epílogo" (pp. 231-233) comienza a ser una contextualización histórica de los hechos; en él se traza un "Retrato de la oligarquía dominante" (p. 299) ${ }^{64}$. En la última edición, dicho retrato —contenido en los últimos tres párrafos del epílogo_ es substituido por un capítulo, en cursiva, el 37:

\footnotetext{
${ }^{63}$ Recordemos que en junio de 1955 fue contra el general Perón, presidente del país, derrocada por las fuerzas leales al gobierno; en septiembre de 1955, nuevamente contra Perón, esta vez triunfante; y en junio de 1956, cuando se desarrollan los hechos relatados en Operación masacre, contra los militares que derrocaron a Perón.

${ }^{64}$ En la tercera edición, “Epílogo” y "Retrato de la oligarquía dominante” forman parte de un único capítulo.
} 
"Aramburu y el juicio histórico" (p. 235), que es un encuadre e interpretación históricos del secuestro y muerte de Aramburu ${ }^{65}$ y a través de este, de los fusilamientos del 56.

\subsection{DEL "QUÉ” AL “CÓMO”: Prólogos e Introducción}

Como quedó indicado en la sección anterior, el "Prólogo" de la edición definitiva es el que comienza a formar parte de Operación masacre a partir de 1964 y que se mantendrá hasta la última edición, de 1972. Recordemos que en la primera, de 1957, el texto abre con un "Prólogo para la edición en libro" (p. 255) y una "Introducción" (p. 257). Estas dos partes serán substituidas, a partir de 1964, por el prólogo mencionado.

Si en 1957, el narrador ${ }^{66}$ declaraba explícitamente que no relataría de qué manera había llegado a obtener "un panorama casi definitivo de los hechos", que prefería exponer resultados (p. 261), en 1964, será precisamente el relato de cómo los obtuvo lo que leeremos en el prólogo. Habían pasado siete años desde la investigación inicial, y la masacre continuaba impune: en 1957, se trataba de buscar la verdad y probar $-\mathrm{y}$ convencer- que la versión oficial de los hechos era falsa; ahora, a partir de 1964, ya probada y demostrada la ilegalidad en la que se llevaron a cabo los fusilamientos $-\mathrm{y}$ la atrocidad que significaron—, el relato trae el "cómo": cómo el narrador se enfrentó a los métodos policiales, cómo sorteó dificultades, cómo enfrentó el orden impuesto por las instituciones oficiales; pero sobre todo, cómo fue posible que aquello ocurriera. Esta será la búsqueda a partir de ahora, marcada por la necesidad de comprender cómo pudo suceder.

\footnotetext{
${ }^{65}$ Aramburu, quien era presidente de facto cuando tiene lugar la "operación masacre", fue secuestrado, juzgado y condenado a muerte por un comando Montonero, en 1970.

${ }_{66}$ Aunque en la edición definitiva no consta, en la de 1957, el prólogo está fechado ("La Plata, julio de 1957") y firmado: "R. J. Walsh" (WALSH, 1957, p. 10). En la segunda edición, solo aparece la fecha ("Buenos Aires, abril de 1964") (WALSH, 1964, p. 144); en las siguientes no constan ni firma ni fecha. A pesar del borramiento del nombre, el "yo" que narra en el prólogo se identifica como autor. Dice Valeria De Marco, al referirse al narrador de La escritura o la vida de Jorge Semprún: "Neste romance, como se dá com freqüência na literatura de testemunho, relativiza-se a necessária operação de distinguir as diferentes funções do "eu" na construção do texto. Jorge Semprún identifica-se no texto, e assim designa o indivíduo que é personagem, personagem-narrador e o autor, indicando para o leitor que sua história elide essas medições, pois não é um produto da imaginação. Mas isso não equivale a dizer que o romance não seja uma obra de ficção. Trata-se de um novo modo de representar a instância autoral, aludindo à sua instabilidade e precariedade." Manuscrito presentado en las "Jornadas sobre Memoria y Testimonio", organizadas por la cátedra de Teoría política y Teoría Estética en la Facultad de Ciencias Sociales de la Universidad de Buenos Aires, julio de 2002.
} 
Relatos del "qué" y del "cómo": dos formas de resistir, por contenido y por forma, al discurso del Estado. Pero también, son estrategias narrativas diferentes, en tiempos diferentes. Si en 1957, los interlocutores de Walsh creían, como él había creído, en el gobierno de la "revolución libertadora", eso hacía que fuese urgente relatar qué había ocurrido en realidad ${ }^{67}$. En 1964, la situación había cambiado tanto para el autor como para el público lector ${ }^{68}$.

Para acompañar estos cambios, en lo que sigue analizaré prólogos e introducción siguiendo el orden cronológico de las ediciones.

\section{"Prólogo para la edición en libro" (1957)}

Este prólogo es una respuesta y una toma de posición. Respuesta "a timoratos y pobres de espíritu" que cuestionan al narrador por, dicen, colaborar periodísticamente con la prensa nacionalista al publicar la denuncia de la masacre en sus páginas. Toma de posición, porque Walsh los enfrenta; y en ese acto, está enfrentando a los que hasta ese momento eran sus pares ideológicos. El tono del prólogo es de urgencia e indignación ante los hechos, pero sobre todo ante los iguales. Tal urgencia se reproduce en la propia localización del prólogo, colocado antes de la contextualización (en la Introducción) de lo que va a ser narrado.

El relato comienza con fechas y lugares de publicación de Operación masacre antes de que se transformara en libro y enseguida, en la declaración de intenciones, el narrador explica el porqué de publicar su denuncia en la "aguerrida prensa nacionalista":

Escribí este libro para que fuese publicado, para que actuara no para que se incorporase al vasto número de las ensoñaciones de ideólogos. Investigué y

\footnotetext{
${ }^{67}$ Pues si se trataba de un hecho arbitrario y aislado, perpetrado por algunos pocos, la denuncia ayudaría a sanear ese régimen en el que se creía.

${ }^{68}$ Entre 1955 y 1965 emerge, entre la intelectualidad argentina, una Nueva Izquierda; el golpe de 1955 operó una recomposición "sobre la escena política [que] acarreó efectos profundos en las vinculaciones de la intelectualidad de izquierda con la élite liberal, con la cual había mantenido relaciones ineludibles en su mutua oposición al régimen peronista." (Oscar Terán, apud Kraniauskas) (KRANIAUSKAS, 2000, p. 106107).
} 
relaté estos hechos tremendos para darlos a conocer en la forma más amplia, para que inspiren espanto, para que no puedan jamás volver a repetirse. ( $p$. 255)

Tal vez el narrador dude frente al hecho de aceptar la oportunidad que le dan las páginas de la derecha, pero ante la urgencia prefiere explicar. Este aspecto se manifiesta en sus afirmaciones sin matices y en los "ataques" a una parte de los posibles interlocutores: sus iguales, que son antiperonistas, que se consideran de izquierda ${ }^{69}$, y apoyan, hasta ese momento, a la Revolución Libertadora. Como lo que está haciendo Walsh es denunciar al gobierno, se le hace necesario escribir este prólogo explicativo.

Además, el prólogo trae el perfil de los lectores que el narrador tiene en mente: por un lado, los aliados que lo ayuden a denunciar a la "gente [...] práctica que tortura y mata" y al "torturador que a la menor provocación se convierte en fusilador"; dice que escribe para interlocutores que se caractericen por su "coraje civil”. Por otro, también está pensando en los "timoratos y pobres de espíritu"; prejuiciosos políticamente, demasiado pragmáticos frente a situaciones que "exigen reacciones casi instintivas, capaces de justificar la condición humana" (p. 256). Estos últimos, por lo menos hasta la investigación y escritura del libro, eran sus iguales, los que pensaban como él. La urgencia y la indignación son tanta que para justificar la condición humana habla de reacciones instintivas: un contrasentido.

También se desprenden de este prólogo las raíces éticas que movilizan al narrador, que lo llevan a relatar los hechos y que le producen la indignación y el espanto que permiten la comparación de Argentina con la Alemania nazi. Ambos sentimientos podrían paralizar, sin embargo aquí tienen un efecto contrario: generan un movimiento de resistencia que se manifiesta, a nivel de la acción, en la investigación de los hechos, en la denuncia, en la escritura. En esta hay una búsqueda para nombrar los hechos en forma adecuada y precisa y una persistencia frente a la dificultad de hacerlo. Me refiero, por ejemplo, a la yuxtaposición de sustantivos — “atropello", "cobardía”, "asesinato" - intentando rodear, encontrar la palabra acertada. Sin embargo, esta parece escabullirse, por la propia naturaleza de los hechos; la elección de la palabra "atropello" para referirse a la

\footnotetext{
${ }^{69}$ Tal vez, se puede hablar de un repudio a la violencia "abstracto", pues sin duda se desconoce la violencia que subyace al orden que apoyan.
} 
experiencia de unas víctimas que, más que sufrir atropello, fueron ultrajadas parece insuficiente.

\section{“Introducción” (1957)}

Una vez definido el lector y declarados los objetivos, leeremos el relato de las diferentes etapas de la investigación. La "Introducción" a la primera edición de Operación masacre es una larga contextualización: cuenta desde el momento en que el narrador se entera de la masacre de José León Suárez hasta que se plantea el conflicto jurisdiccional entre tribunales civil y militar y el caso pasa a ser juzgado en este último ámbito. También está ahí relatado el pasaje en la conciencia del narrador de un momento inicial de descreimiento - “La historia me pareció cinematográfica, apta para todos los ejercicios de la incredulidad" (p. 257) — a la reflexión sobre evidencias y pruebas y finalmente a la decisión de mostrar los resultados de la investigación. Entre el momento inicial y el final, se relata el contacto con el Dr. Doglia, Jefe de la división Judicial de la Policía de la Provincia, quien se refiere a los "métodos" de dicha fuerza: torturas, asesinatos, impunidad; también se lee allí el encuentro con Livraga, el sobreviviente de la masacre que se anima a denunciar "a quien resulte responsable"; nos enteramos cómo y cuándo la historia se hace pública; y cuál es la posición política del narrador —no es nacionalista ${ }^{70}$, no es peronista-.

El orden del relato es cronológico: el narrador apunta minuciosamente los días y los períodos — mañana, tarde, noche - en que va consiguiendo cada vez más información, tal vez, como una estrategia de legitimación frente al lector. El relato es permanentemente interrumpido con comentarios e informaciones que van entretejiendo una red de conocimiento sobre la situación, sobre hechos concretos, que ya se producían dentro de las instituciones del Estado, en particular la policial.

Aun así, es un texto marcado por la tensión entre lo que se sabe y no se sabe, entre lo que se cree y lo que no se cree: ¿existe un fusilado sobreviviente?, ¿es inocente?, ¿la

\footnotetext{
${ }^{70}$ Aunque en una entrevista publicada en la revista Siete Días, de 1969, dice lo contrario. Walsh, Rodolfo. Ese hombre y otros papeles personales. Argentina, Seix Barral, 1966.
} 
policía lo fusiló?, ¿el Estado es responsable? Dicha tensión generará oscilaciones, ambigüedades, contradicciones.

La "Introducción" comienza con la noticia ${ }^{71}$ de cómo el narrador se enteró de los fusilamientos:

La primera noticia sobre la masacre de José León Suárez llegó a mis oídos en la forma más casual, el 18 de diciembre de 1956. Era una versión imprecisa, propia del lugar —un café - en que la oí formulada. De ella se desprendía que un presunto fusilado durante el motín peronista del 9 y 10 de junio de ese año sobrevivía y no estaba en la cárcel. (p. 257)

Al referirse al fusilamiento como "la masacre...", el artículo definido podría llevar a pensar que el autor se dirige a interlocutores que saben a qué se hace referencia. Es verdad que, para el momento en que se publica el libro, ya había aparecido el tema en algunos medios periodísticos, pero esto no necesariamente significa que todos lo conociesen: la elisión ${ }^{72}$ será una de las marcas de Operación masacre, atravesada por tensiones entre lo que el narrador da por sabido y aquello que explicita demasiado, entre lo dicho y lo no dicho; entre el silencio y los rumores.

Además, el "la" puede estar señalando que no es cualquier masacre, es la masacre que, al poner al descubierto un aspecto desconocido del mundo en el que el autor vive, le cambia la vida: de periodista a investigador; de investigador a narrador.

La tematización de la casualidad, que también se lee en este primer párrafo, será clave para reforzar la sensación del absurdo que significó el fusilamiento para las víctimas: fueron encuentros casuales que las llevaron al lugar donde las detuvieron. La casualidad predominando sobre la causalidad tendrá desdoblamientos en la estructura de toda la primera parte.

\footnotetext{
${ }^{71}$ Uso la palabra "noticia" en el sentido periodístico. En este ámbito lo esencial de la noticia es que siempre responde las preguntas ¿quién? ¿qué? ¿cuándo? ¿dónde? ¿por qué? Pero, otra característica de la noticia es la oración simple, que en este caso no es lo que usa Walsh.

72 Varios autores señalan la elisión como un rasgo de estilo en la escritura de Walsh, ver, por ejemplo, (AMAR SÁNCHEZ, 1997).
} 
Siguiendo adelante con el relato, a continuación, se presenta a Doglia como un abogado de 32 años que es posible que "tuviera los nervios destrozados por una lucha sin cuartel librada durante varios meses [...] contra los 'métodos' policiales de que era testigo" [la cursiva es mía]; delatado y amenazado por sus pares por haber denunciado los "métodos"; ignorado por el Ministerio de Gobierno; tiene poca fe en el periodismo y la justicia (pp. 258-259). Así, para cuando se narra el encuentro con Livraga, encuentro clave en la vida del autor, ya tenemos un panorama del clima de violencia que reina dentro de la policía de la provincia de Buenos Aires y de la arbitrariedad e impunidad dentro del sistema judiciario.

Observemos que el uso de los lugares comunes (clisés) - "nervios destrozados", "lucha sin cuartel"-, en la presentación de Doglia, propios de los diarios populares, contrasta con la "sobriedad" y cautela de los primeros párrafos - "versión imprecisa", "presunto fusilado"- y crea una extrañeza que, generando una tensión que inmediatamente llama la atención del lector, no permite una lectura sin compromiso, como parecería posible en un primer momento debido al lenguaje y sintaxis accesibles.

Las interferencias del narrador son permanentes: opina, comenta, vaticina, pero también selecciona y ordena la información y no oculta ninguna de estas operaciones. Hay una tensión entre afirmar taxativamente y ponderar:

La historia me pareció cinematográfica, apta para todos los ejercicios de la incredulidad. Esta, sin embargo, puede ser apenas la máscara de la sabiduría. Suele ser tan ingenuo el incrédulo absoluto como el que todo lo cree; pertenecen en el fondo a una misma categoría psicológica. (p. 257) [Los subrayados son míos]

Observemos que el narrador primero plantea lo que le parece, una impresión personal que es, por lo tanto, discutible. Luego, el "puede ser" deja sobreentendido que puede no ser también, así como el "suele" implica "muchas veces", pero no "siempre". Sin embargo, al usar el sustantivo "máscara" — con sus sentidos figurados de pretexto, de disfraz, de disimulo- acompañado con el "apenas" que disminuye el valor de "incredulidad", ya está preparando el camino para la afirmación final, que es en definitiva una toma de posición definida por la locución adverbial "en el fondo" — en realidad, en lo esencial— el incrédulo 
absoluto y el que todo lo cree pertenecen a "una misma categoría psicológica". Obsérvese cómo el narrador va construyendo su posición, la va rodeando, se va aproximando.

Otra tensión que se va construyendo a lo largo de esta introducción es la de creer o no en el gobierno de la Revolución Libertadora; si la violencia se le achaca al gobierno o a la policía:

Un oficial de las fuerzas armadas ... a quien relaté los hechos antes de publicarlos, los calificó con toda buena fe de "novela por entregas"73 (p. 257)

Pero allí [Servicio de Informaciones] un burócrata que bien podría pasarse el resto de sus días estudiando en los textos elementales las normas para cultivar al informante ... no encontró nada mejor que delatarlo ${ }^{74}$. (p. 258)

... un señor subsecretario llegó a la conclusión de que algo había, pero no se sabía qué. (p. 258)

Este es el servicio que prestan al actual Gobierno algunos funcionarios. (p. 259) [en todos los casos, la cursiva es mía]

Hasta aquí, aparentemente, el narrador cree que son solo algunos funcionarios aislados los que propician la impunidad. Sin embargo, si prestamos atención a una afirmación anterior en la propia introducción:

Y todo esto bajo el régimen de una Revolución Libertadora que muchos argentinos recibieron esperanzados por que creyeron que iba a terminar con los abusos de la represión policíaca. (p. 258) [la cursiva es mía],

surge inmediatamente la pregunta: ¿por qué el uso de la tercera persona del plural (ellos)? ¿por qué el narrador no se incluye entre los que "recibieron" y "creyeron" ? Dudas que se afirman aún más cuando leemos, un poco hacia adelante: "Tampoco soy ya un partidario de la revolución que —como tantos-creí libertadora." (p. 263). La contradicción puede ser que provenga del hecho de que Walsh, al igual que Doglia, no quiera que su denuncia sea usada por la oposición; también hay en él una decidida voluntad de ver y presentar "las dos caras de la moneda":

\footnotetext{
${ }^{73}$ En la primera edición, esto consta en nota a pie de página (WALSH, 1957 i, p.11).

${ }^{74}$ Obsérvese la contradicción entre considerar que el burócrata puede aprender cómo se protege a un testigo y el verbo delatar que denota intencionalidad.
} 
Admitiendo que sea necesario —y no lo discuto— suscitar una reacción pública contra el terrorismo de abajo, ¿no es también urgente fundamentar un gran movimiento de opinión que aniquile para siempre a los terroristas de arriba, a los torturadores, a los fusiladores?

Empiezo a convencerme que es una desgracia, una especie de tara psicológica de la que huye la gente respetable, ver siempre las dos caras de la moneda... (p. 286-287)

Sin embargo, y creo que aquí hay una clave para leer Operación masacre, también parece tratarse de una intuición del narrador de que la violencia no es apenas producto de algunos funcionarios aislados, como surge de la cita antes transcripta - “...bajo el régimen de una Revolución Libertadora"-

Esta "Introducción" contiene otra declaración de intenciones, esta vez literarias, que afirma una elección: mostrar los resultados obtenidos de la investigación y no cómo se llegó a ellos:

No relataré aquí cómo se fue desenredando la madeja, cómo a partir del hilo inicial se llegó a establecer un panorama casi definitivo de los hechos; a partir de un personaje del drama localizar a casi todos los demás. Prefiero exponer los resultados obtenidos. (p. 261)

El narrador parece negarse a relatar la "aventura" que vivió como investigador; se resiste a lo lúdico y entretenido de la literatura policial de enigma ${ }^{75}$, género que le es familiar. Sin duda, se trata de una decisión ética. Pero, la afirmación citada surge después que ha relatado su encuentro con Livraga (el "presunto" fusilado sobreviviente) y, a la manera de un detective, ha reflexionado sobre pruebas y evidencias; ordenadamente ha enumerado hechos - la demanda, la existencia de otro testigo, las heridas - y discutido todas las posibilidades.

Además, la renuncia a relatar el "cómo" podría traducirse en una mera exposición de los hechos, pero a esto el narrador también resiste; resiste a la transitoriedad que caracteriza

\footnotetext{
${ }^{75}$ Según Tzvetan Todorov: "na base do romance de enigma encontramos uma dualidade [...] Esse romance não contém uma, mas duas histórias: a história do crime e a história do inquérito...", "Tipologia do romance policial", As estruturas narrativas. São Paulo, Perspectiva, 1979, (p. 93-104)
} 
al texto periodístico ${ }^{76}$. La declaración de intenciones, en su propia forma, muestra la tensión entre el "qué" y el "cómo". Después de la primera oración siguen dos — "cómo a partir del hilo inicial...", "a partir de un personaje..."-, que aunque no dan detalles, explicitan una forma de conocer los hechos y sus protagonistas. Dos oraciones que niegan, de alguna manera, la primera y la última. Movimiento que se repite en el propio uso de la lengua: obsérvese la oscilación entre la primera persona ("no relataré...") y la forma impersonal (“se llegó a establecer...”).

Vemos así que, hasta aquí, además de mostrar resultados, el narrador ha reconstruido la manera en que llegó a creer en la historia del fusilamiento. Es decir, cómo ha pasado del momento inicial de incredulidad a comprender la ofensa que siente la víctima:

... un hombre tiene que sentirse profunda e injustamente dañado, tiene que sentirse inocente para presentar una denuncia así contra toda una Potencia como es la policía provincial. (p. 261)

El recurso de la reiteración ("tiene que sentirse..."), constante en Operación masacre, además de la intensificación de significados que le es característico, será una de las estrategias que dispone al lector a la simpatía hacia las víctimas.

Relatar la masacre significó, para el narrador, acercarse al peronismo y a los peronistas y esa aproximación se refleja en la forma de nombrarlos. Hay un desplazamiento, una graduación, que va desde la referencia al enemigo personal ${ }^{77}$ a "temibles seres", a "seres humanos equivocados", a "humillados y ofendidos", a "sectores obreros", a peronistas (pp. 263-264). Es decir, la mirada del narrador va de la exclusión, donde el Otro asusta, a la categoría política, grupo capaz de organizarse y defenderse, con voz y práctica política.

También hay en la "Introducción" una declaración de objetivos:

\footnotetext{
${ }^{76}$ Amar Sánchez, al discutir la diferencia entre los textos periodísticos y lo que ella denomina no-ficción o testimonio, señala: “...se trata [la no-ficción] de una forma con una legalidad propia y el gesto que lo [sic] separa de la crónica determina su autonomía: los textos son relatos, liberados de la inmediatez y dispersión que caracterizan las notas periodísticas." (AMAR SÁNCHEZ, 2000, p. 2005).

77 "La mayoría de los periodistas y escritores llegamos, en la última década, a considerar al peronismo como un enemigo personal." (p. 263).
} 
Reitero que esta obra no persigue un objetivo político ni mucho menos pretende avivar odios completamente estériles. Persigue —una entre muchas [sic] — un objetivo social: el aniquilamiento a corto o largo plazo de los asesinos impunes, de los torturadores, de los "técnicos" de la picana que permanecen a pesar de los cambios de gobierno, del hampa armada y uniformada. (p. 264)

En 1957, y a pesar de todas las evidencias presentadas por Doglia, el narrador todavía no ve al sistema policial totalmente identificado con el gobierno -rever esta creencia y consignarla en Operación masacre le llevará un poco más de diez años, como se puede leer en "retrato de la oligarquía dominante" (p. 299)—. Así, al declarar propósitos "apolíticos", se puede pensar en una estrategia narrativa que adhiere a la postura de los posibles lectores.

Notemos también la carga de indignación que lleva al narrador a hablar de "aniquilamiento". Sin duda, esos "aniquilables" eran asesinos y estaban impunes, pero ese tipo de revancha solo generaría más violencia; quizás se pueda pensar que, una vez más, el pasaje citado recupera las ambigüedades de las que hablé al principio, determinadas por una tensión mayor, que recorre todo el texto: creer o no creer.

\section{"Prólogo" (1964/1969/1972)}

Entre la primera y la segunda edición de Operación masacre pasan varios años (siete) y varias cosas en la vida de su autor y del país. Y eso se refleja en el nuevo "Prólogo". A diferencia de lo que se anunciaba en la primera edición —relatar los resultados -, la estrategia, ahora, será relatar "cómo" acontecieron los hechos: cómo el narrador se enteró de los fusilamientos, cómo realizó la investigación, cómo llegó a los sobrevivientes, cómo surgió el libro, cómo lo publicó.

Además, en el Prólogo e Introducción de 1957, el narrador declaraba y aclaraba intenciones y objetivos, y era movido por la urgencia y el deseo de acción; en el de 1964, mucho de eso queda atrás. Lo que subyace a esta escritura es intentar comprender: el narrador quiere compartir con el lector su necesidad de entender cómo llegó a envolverse en la investigación que le imprimiría un rumbo nuevo a su vida: "Operación masacre 
cambió mi vida. Haciéndola, comprendí que, además de mis perplejidades íntimas, existía un amenazante mundo exterior" (WALSH, 1996, p. 12).

Los caminos de dicha búsqueda pasan por la evocación de diferentes momentos del pasado que van desde el momento de recibir la noticia de los fusilamientos hasta la publicación de la segunda edición de Operación masacre. Entre ambos, está el relato del encuentro con algunos de los sobrevivientes y cómo fueron siendo descubiertos; hay un sumario de las peripecias vividas por el narrador durante la investigación y de la dificultad para publicar los resultados de la misma.

En la tarea de rememorar, lo que la memoria trae es el encuentro con la arbitrariedad, la ofensa y la muerte; narrar es revivir aquellos momentos: los hechos y el recuerdo sacan al narrador de su mundo de seguridades y perplejidades individuales. De ahí que a cada paso el relato de la acción sea aplazado, que haya detenciones, desvíos y cambios de tono.

El recuerdo viene con imágenes de muerte y violencia: primero la de la muerte del conscripto y su "grito desgarrador"; después, la del "hombre con los sesos al aire"; seis meses más tarde son los agujeros en el cuerpo de Livraga, "los ojos opacos donde se ha quedado flotando una sombra de muerte", el casi llanto, la desesperación y la vergüenza; a continuación es la "película que ... gira y gira" dentro de la cabeza de Giunta - "el otro" que se salvó- y la ofensa que lleva dentro; finalmente el encuentro con el "enterrado vivo", Don Horacio y su imagen de desvalido, desprotegido. Este recuento cronológico será interrumpido, a cada paso, por el relato de otras circunstancias.

El primer recuerdo es de cómo, cuándo y dónde se entera el narrador sobre los fusilamientos:

La primera noticia sobre los fusilamientos clandestinos de junio de 1956 me llegó en forma casual, a fines de ese año, en un café de La Plata donde se jugaba al ajedrez, se hablaba más de Keres o Nimzovitch que de Aramburu y 
Rojas $^{78}$, y la única maniobra militar que gozaba de algún renombre era el ataque a la bayoneta de Schlechter en la apertura siciliana. (p. 17)

Las oraciones usadas para describir el clima que se vive en aquellos días ("se hablaba más de...", "la única maniobra...") pueden ofrecer algún tipo de información sobre el contexto histórico, pero desvían la atención del asunto principal: ¿qué fusilamientos son esos? El "los" antes de fusilamientos, puede crear un clima de expectativa para los lectores que no vivimos aquellos tiempos; también, como en el "Prólogo" de la primera edición, puede llevar a pensar que se trata de un dato compartido entre narrador y lector; pero, a diferencia del párrafo inicial de aquel prólogo, que indicaba el lugar preciso de la masacre ("José León Suárez") y entraba rápidamente en el asunto del "presunto fusilado", aquí solo se enuncia el hecho y el relato se desvía hacia La Plata y el café.

Recordar cómo le llegó la noticia de los fusilamientos, hace que el narrador evoque aquella otra noche del levantamiento militar, seis meses antes, cuando la violencia le había "salpicado las paredes". Lo que vuelve a su memoria es el momento en que el tiroteo, confundido con un festejo, lo saca de "las suaves, tranquilas estaciones" y lo arroja a otro espacio, a otra vida. Recuerda la lucha por volver a su casa y la "incoercible autonomía" de sus piernas para dirigirse a la estación de ómnibus; y cuando finalmente logra llegar a su casa, ubicada frente al cuartel donde se producía una parte de los enfrentamientos, ésta estaba tomada por soldados; y es en ese espacio familiar que escucha morir a un conscripto.

La rememoración, indicada por el verbo en tiempo pretérito, va siendo jalonada por un "recuerdo", en el presente de la escritura del prólogo (1964): el relato comienza con el narrador situado en 1964, evocando la noche de diciembre de 1956, en la que se entera de los fusilamientos - "La primera noticia [...] me llegó..."-; esa rememoración es la que lo lleva a la otra, la de seis meses antes (junio de 1956), la noche del levantamiento:

Recuerdo cómo salimos en tropel [...] para ver qué festejo era ese... (p. 17)

\footnotetext{
${ }^{78}$ Keres, Nimzovitch y Schlechter eran jugadores de ajedrez y el ataque a la bayoneta es una movida de ajedrez, inventada por este último. Aramburu y Rojas eran el presidente y vicepresidente en la dictadura durante la que transcurren los hechos narrados en Operación masacre.
} 
Recuerdo que después volví a encontrarme solo, en la oscurecida calle 54, donde tres cuadras más adelante debía estar mi casa a la que quería llegar [...] Recuerdo la incoercible autonomía de mis piernas, la preferencia que, en cada bocacalle, demostraban por la estación de ómnibus... (p. 18)

Tampoco olvido que, pegado a la persiana, oí morir a un conscripto en la calle y ese hombre no dijo "Viva la patria", sino que dijo: "No me dejen solos [sic] hijos de puta." (p. 18)

Después de evocar la muerte del soldado, los recuerdos, relatados en tiempo presente y sus correlativos (pretérito perfecto y futuro), se alternarán entre los de la noche de los fusilamientos (junio de 1956) y los del tiempo de la investigación de los hechos y publicación del libro (diciembre de 1957 en adelante); el paso de un recuerdo a otro estará marcado por adverbios - "Después no quiero recordar más... (p. 18), "Ahora, durante casi un año no pensaré en otra cosa... (p. 19)"- y demostrativos — "Así nace aquella investigación, este libro" (p. 19); "Esta ${ }^{79}$ es la historia que escribo" (p. 20)—, que traen la narración al presente.

Y así, comienza una especie de pugna en el tiempo del relato; que se reproduce en la tensión entre recordar o no recordar; entre volver al pasado o no:

Después no quiero recordar más, ni la voz del locutor en la madrugada anunciando que dieciocho civiles han sido ejecutados en Lanús, ni la ola de sangre que anega al país hasta la muerte de Valle. Tengo demasiado para una sola noche. Valle no me interesa. Perón no me interesa, la revolución no me interesa. ¿Puedo volver al ajedrez? (p. 18) [las cursivas son mías]

Además de la contradicción que significa la enumeración de recuerdos detrás de la negativa ("no quiero..."), hay una tensión entre el tiempo de la escritura y el de la noche de la revolución: el "no quiero", antecedido por el adverbio, puede indicar el presente de la escritura del prólogo, pero "anunciando" y "anega", también en presente, remiten a los días de la revolución; "han sido ejecutados", pasado en relación a la noche de junio de 1956, pero traído al presente de la escritura; "tengo" y "no me interesa", en presente, evocan los días del alzamiento. Así, la contradicción pone de relieve la tensión entre la conciencia despolitizada (que querría volver al ajedrez) y la presencia (el repiqueteo) de lo

\footnotetext{
${ }^{79}$ En todas las ediciones, menos en la definitiva, consta "esa" en lugar de "esta".
} 
que no puede ser olvidado y exige una respuesta (salir del ajedrez, investigar y denunciar) Es decir: Valle, Perón, la revolución han atrapado al narrador; la historia lo ha atrapado. El traer al presente el tiempo del fusilamiento indica que el crimen está ahí (o aquí: como crimen impune, la herida sigue abierta en el presente), está en la memoria, y no ha sido olvidado; y esto también es una forma de resistir contra la negación del discurso oficial, contra la no reparación.

La tensión también está en la elección de palabras. En el caso del conscripto, por ejemplo, el narrador probablemente oyó "No me dejen solo, hijos de puta"; pero el vituperio "hijos de puta" produce una ruptura en el lirismo y el ritmo de la descripción. Lo mismo se pude decir de otro pasaje que se encuentra un poco más adelante, cuando es retomado ese recuerdo, el narrador se refiere al grito que oyó de boca del soldado y lo adjetiva con "desgarrador", casi un clisé que parecería empobrecer la narrativa. Sin embargo, pienso que se trata de cuidados del narrador para no volver banal la historia de los fusilamientos. Observemos el siguiente pasaje:

La violencia me ha salpicado las paredes, en las ventanas hay agujeros de balas, he visto un coche agujereado y adentro un hombre con los sesos al aire... (p. 18-19).

Primero una metáfora para hablar de la proliferación de la violencia, después la acumulación de oraciones reforzando la idea de los agujeros, que evocan las balas; al fin el hombre, entre la coloquialidad y brutalidad de "sesos al aire". Estos recursos, producen extrañeza en el lector, lo sacan de la armonía de una narración "tranquila" y le imponen toda la crudeza de la muerte.

También pueden interpretarse como un recurso de extrañamiento algunos comentarios irónicos o casi humorísticos ${ }^{80} \mathrm{o}$ aparentemente innecesarios, como se puede observar en el pasaje siguiente:

\footnotetext{
${ }^{80}$ Tal vez sea a este tipo de "error" al que se refiere Aníbal Ford, en 1972. Después de elogiar la "literatura franca y desacralizada" que produce Walsh, comenta: "...lo que no impide señalar errores y deficiencias que tal vez puedan ser superadas en la medida en que Walsh deje algunos estereotipos, pierda de vista ciertos lectores demasiados [sic] lúcidos [...], limpie zonas de la ironía distanciadora y a veces innecesaria..." (FORD, 1972, p. 318)
} 
...tres cuadras más adelante debía estar mi casa a la que quería llegar y finalmente llegué dos horas más tarde, entre el aroma de los tilos que siempre me ponía nervioso ${ }^{81}$, y esa noche más que otras [...] Mi casa era peor que el café y peor que la estación de ómnibus, porque había soldados en las azoteas y en la cocina y en los dormitorios, pero principalmente en el baño, y desde entonces he tomado aversión a las casas que están frente a un cuartel... (p. 18) [la cursiva es mía]

Como vemos, la narración también oscila entre el relato de lo personal, individual, es decir, de las propias sensaciones y deseos del narrador y lo que está estrictamente relacionado con la investigación. Esto se pone de manifiesto, un poco más adelante, cuando ya se ha contado el encuentro con Livraga, el "fusilado que vive", y las dificultades para publicar la historia: “...nadie me la quiere publicar, y casi ni enterarse. Es que uno llega a creer en las novelas policiales que ha leído o escrito..." (p. 20); o aún, en el agradecimiento a Enriqueta Muñiz:

Pero he tenido más suerte todavía. Desde el principio está conmigo una muchacha que es periodista, se llama Enriqueta Muñiz, se juega entera. Es difícil hacerle justicia en unas pocas líneas. Simplemente quiero decir que si en algún lugar de este libro escribo "hice", "fui", "descubri", debe entenderse "hicimos", "fuimos", "descubrimos". Algunas cosas importantes las descubrió ella sola, como los testimonios de los exiliados Troxler, Benavídez, Gavino. En esa época el mundo no se me presentaba como una serie ordenada de garantías y seguridades, sino más bien como todo lo contrario. En Enriqueta Muñiz encontré esa seguridad, valor, inteligencia, que me parecían tan rarificados a mi alrededor. (p. 21) [la cursiva es mía]

Si me permití transcribir todo el párrafo es porque aquí se concentran algunas de las tensiones ya señaladas: por un lado, observemos que en el mismo párrafo consta el agradecimiento por el trabajo compartido, pero también una especie de confesión más íntima que habla de inseguridades e incertezas del narrador; por otro, la oración "Desde el principio está conmigo..." remite a 1957, el tiempo de la investigación, pero "En esa época..." indica que el tiempo de lo relatado ha vuelto a 1964, el de la escritura del prólogo.

En 1957, el universo de interlocutores a los que se destinaba Operación masacre era bastante amplio: desde la propia policía, como se puede observar en esta cita:

\footnotetext{
${ }^{81}$ Se dice popularmente que el aroma de los tilos tranquiliza. En las calles y avenidas de La Plata, donde vivía Rodolfo Walsh en la época de la Revolución de Valle, abunda este tipo de árboles hasta hoy.
} 
Sé que el señor Jefe de Policía de la Provincia de Buenos Aires ha demostrado una gran curiosidad — que supongo insatisfecha hasta ahora — por saber quién era el autor de los artículos en que presumiblemente se le atacaba. En realidad debo decir que no ha existido intención de atacar su persona... (p. 265)

hasta el lector "común", pasando por los "iguales" del narrador. En el prólogo que estamos tratando, ese espectro se reduce; el último párrafo, después de ser comentado a grandes rasgos lo que ha sido substituido entre una edición y otra - se ha reemplazado parte de la evidencia usada en 1957 "por otra más categórica" - finaliza afirmando: "Frente a esta nueva evidencia, creo que la polémica queda descartada." (p. 25), es decir, frente a la evidencia del "Expediente Livraga", versión oficial de los hechos, el narrador no está dispuesto a polemizar más sobre los hechos, sobre lo que pasó, lo cual excluye a aquellos que todavía no crean o nieguen la masacre.

\subsection{CÓMO ACERCARSE A LAS VÍCTIMAS: "Las personas"}

La trama de la primera parte de Operación masacre pone de relieve la vida cotidiana de las víctimas, con todo lo que tiene de habitual, y un movimiento que se repite: en un día como cualquier otro, varios de los protagonistas se van encontrando casualmente y se dirigen hacia el lugar donde serán detenidos; pero esto ellos no lo saben. Por eso, la irrupción policial $\longrightarrow \mathrm{y}$ todas sus consecuencias - significará una ruptura, un quiebre en la vida de esas las personas.

Esta primera parte describe el universo familiar y social de las víctimas. Allí nos deparamos con obreros, con empleados, con militantes, con sus compañeras e hijos; personas comunes, con valores, sueños, luchas y frustraciones; y sabemos desde el prólogo que estas personas serán fusiladas. Son fragmentos de las últimas horas del día 9 de junio, la víspera de la masacre. El momento en que empieza el relato es prácticamente el mismo para todos los protagonistas: algunas horas antes de la detención; los espacios son sus casas, sus barrios, sus lugares de trabajo. Culmina con la llegada de la policía al departamento en el cual están reunidos para escuchar una pelea de box. 
El movimiento de reiteración en la acción y en la forma del relato - encuentro casual de protagonistas; descripción del día a día - quebrado por la irrupción de la policía se repetirá en la estructura general de la primera parte de Operación masacre. Se puede observar que en los capítulos 1 a 12 hay una especie de circularidad ${ }^{82}$ : "Carranza" y "Garibotti" son obreros más o menos pobres; "Don Horacio" y "Giunta" pertenecen a la clase media; en los capítulos 5 a 9, "Díaz: dos instantáneas", “Lizaso", etc., están los "conspiradores" ${ }^{3}$; "Brión" y "Livraga", nuevamente pertenecen a la clase media; y cierra la presentación de las personas con "Me voy a trabajar", dedicado a otro obrero muy pobre $^{84}$; el capítulo 13 rompe esa semirregularidad, con una especie de síntesis y la llegada de la policía.

Al examinar más detalladamente cada uno de los capítulos, se observa que el ordenamiento corresponde también a una forma que evoca la de la épica; es decir, hay un intento de representar todo un mundo de seres íntegros. Así, el primer capítulo está centrado en el "hombre", el obrero trabajador y perseguido injustamente; en el siguiente, está el hombre y la relación con la casa y la familia; en los demás, están el hombre y el barrio, el trabajo y la "historia": la de vida; la reciente del país (de los años 40 y 50 ); la historia presente, la que está siendo narrada. Y, a su vez, cada uno de estos aspectos traspasa cada capítulo configurando una masa densa.

Para reconstruir y reconocer el universo de los protagonistas, el narrador va ocupando diferentes sitios en relación a ellos, a los hechos y a la escritura: observa el mundo desde el lugar de las víctimas, confunde su voz con la de las personas que entrevistó, se

\footnotetext{
${ }^{82}$ Horacio González, en "Bastardillas y metamorfosis", dice que "Walsh suele parangonar hechos presentes y pasados, pero en el fondo su visión es la de una historia en eterno retorno, que se reanuda por signada por la circularidad de una culpa." (GONZÁLEZ, 1998, p. 22). Aunque la lectura que hago aquí no es en el sentido de la culpa, es interesante tener en cuenta la idea de circularidad en la visión de Walsh.

83 Tomo esta palabra del final del prólogo de la edición definitiva de Operación masacre: "Entonces puedo sentarme, porque ya he hablado con sobrevivientes, viudas, huérfanos, conspiradores..." (p. 25).

${ }^{84}$ Aunque a veces no está explicitada la clase social, el dato del tipo de vivienda es una pista para reconocerla: recordar que Don Horacio es el dueño "de toda la finca" (p. 42) donde van a transcurrir parte de los hechos; que Mario Brión vive en un "chalet con un jardín" (p. 63) y Vicente Rodríguez en "esa casa pobrísima que alquila" (p. 71).
} 
"apropia" de palabras y modos ${ }^{85}$; es así que se acerca a ese mundo, intenta conocerlo y entender lo acaecido.

Aparentemente, se trata de una "galería" de retratos; los personajes están construidos a partir de las personas reales con pocos datos: nombre propio, descripción física y de carácter, relación con la familia, los amigos, el barrio, el trabajo. Pero, por la remisión al pasado, los personajes ganan densidad: de cada uno habrá una pincelada que evoca otro tiempo. Además, como consecuencia del fusilamiento, esas personas integran un colectivo y así lo deja registrado el narrador al juntarlos en una única parte, sin jerarquías, sin héroes. Son capítulos cortos, de extensión desigual, pero el narrador construye uno para cada persona. Y, hay más. El narrador sabe de la desproporción entre un acto posible (participar en el alzamiento) y el castigo (fusilamiento) y es ese saber el que guiará la construcción de cada uno de los personajes.

\section{Los obreros}

El capítulo que abre la primera parte de Operación masacre relata las últimas horas que Nicolás Carranza, obrero peronista, pasa con los seis hijos y su compañera, Berta Figueroa. El capítulo comienza y se demora en el momento en que este protagonista llega a su casa y, a partir de ese movimiento — el de llegada—, conocemos la relación que tiene con los hijos, su mujer y el barrio y sabemos algo de su pasado. Entremezclado con la descripción, hay pinceladas de las actividades familiares la noche del 9 de junio: Nicolás Carranza juega con sus hijos, cena, conversa con su esposa y se va. Junto con ese relato vienen retazos de una cotidianeidad marcado por la injusticia y la persecución.

Nicolás Carranza era peronista y estaba enterado del alzamiento; pero eso no justifica su asesinato. Y, como dije, es la injusticia de ese acto la que guiará la construcción del capítulo. Así, antes de enterarnos de que Nicolás Carranza es peronista, sabremos que está muerto:

\footnotetext{
${ }^{85}$ Ricardo Piglia observa un rasgo estilístico, que denomina "desplazamiento", tanto en "Cartas a mis amigos" y "Carta a Vicki" como en el prólogo a Operación masacre (PIGLIA, 2000). Aquí a lo que me refiero es a otro aspecto: como veremos, palabras y modos de los interlocutores se "mezclarán" a las del propio narrador.
} 
Nicolás Carranza no era un hombre feliz, esa noche del 9 de junio de 1956. Al amparo de las sombras acababa de entrar en su casa, y es posible que algo lo mordiera por dentro. Nunca lo sabremos del todo. Muchos pensamientos duros el hombre se lleva a la tumba, y en la tumba de Nicolás Carranza ya está reseca la tierra. (p. 31)

En este párrafo, que abre el capítulo, se puede observar cómo la inversión sintáctica en la primera oración resalta la condición de hombre, de ser humano y de ciudadano de Nicolás Carranza. Al comenzar el relato con el nombre, el apellido y la palabra "hombre", el relato devuelve al protagonista a la condición de ciudadano y de ser humano, condición que le fue negada con el fusilamiento.

Nicolás Carranza está muerto y esto es irreparable. La noción de que "algo" se ha perdido para siempre va creciendo desde la conjetura "es posible...", hasta la afirmación definitiva: "en la tumba... ya está reseca la tierra". La repetición de la idea de muerte, evocada por la palabra "tumba", le da al párrafo un tono de tristeza y melancolía. Pero, la manera como somos introducidos en esa melancolía es sutil: en la primera oración aparece el adjetivo "feliz", pero con una negación, sin alusión directa a la tristeza; y, aunque "ser" y "feliz" juntos denotan "esencia", el narrador aclara inmediatamente que es "esa noche", indicando que se trata de un estadio temporal, como si no quisiese sumergirse —ni que nos sumerjamos - de una vez en la melancolía.

Se puede entender "amparado por las sombras" en sentido literal: la oscuridad ayuda a Nicolás Carranza a esconderse. Pero también la inmaterialidad de la sombra y el propio participio "amparado" evocan el desamparo, la soledad del hombre. Y entonces, toda la rabia y el dolor frente a esa soledad podemos imaginarlos contenidos en los pensamientos duros que tal vez lo muerdan por dentro.

No hace falta seguir muy adelante con la lectura para percibir que tristeza, soledad y desamparo es lo que siente la compañera de Nicolás Carranza, Berta Figueroa; y en ese tono está compuesto el capítulo. Después del primer párrafo, los dos siguientes describen cómo la familia recibió a Nicolás Carranza; en el primero, el padre juega con los hijos; el segundo muestra a Berta: 
Su compañera, Berta Figueroa, alzó los ojos de la máquina de coser. Le sonrió con mezcla de pena y alegría. Siempre era igual. Siempre llegaba así su hombre: huido, nocturno, fugaz. A veces se quedaba una noche, después desaparecía las semanas. Por ahí le hacía llegar un mensaje: estaba en casa de tal amigo. Y entonces era ella quien iba a su encuentro, dejando los chicos a alguna vecina, y pasaba con él unas horas transidas de temor, de zozobra, de amargura de tener que dejarlo y esperar el lento paso del tiempo sin noticias suyas. (p. 31-32)

Aunque en la sonrisa haya un componente de alegría, lo que predomina es la tristeza, marcada no sólo por las enumeraciones que evocan al hombre perseguido, al miedo y a la angustia, sino también por la reiteración tanto de palabras como de estructuras (“Siempre era...", "siempre llegaba..."). El adverbio "siempre" y el imperfecto, por un lado, indican la repetición del día a día; por otro, evocan la fuerza y la presencia, la actualidad de los hechos en la familia de Nicolás Carranza.

Tristeza, melancolía y muerte; hijos pequeños con quienes juega el padre; son informaciones que predisponen a la "simpatía" en relación al protagonista, la misma que se adivina en el narrador. Y, ahora sí, sabremos, en una única oración que Nicolás Carranza es peronista.

Pero, no es solo el tono de Berta lo que trae el relato. A medida que el narrador profundiza en la vida cotidiana del protagonista y su familia, el habla coloquial se va mezclando con su voz: "después desaparecía las semanas" o "dejando los chicos"; en la primera oración sobra el artículo, en la segunda falta la preposición "a". Y, un poco más adelante, cuando refiere el episodio de la detención de la hija de doce años, leemos: "Se les disparó en Tucumán." (p. 33) [las cursivas son mías], donde "se disparó" también es una forma coloquial para decir que "se escapó".

Pensemos también en los cambios que se operan en el foco narrativo. El capítulo, al ser titulado solo con el apellido del personaje, "Carranza", comienza marcando una cierta distancia. En el primer párrafo ya constan nombre y apellido, lo que le da un carácter particular al personaje (no es cualquier "Carranza", es "Nicolás"). Un poco más adelante, cuando se describe la relación del protagonista con el barrio, se lee: 
...cuando en furtivos regresos como éste algún chico del barrio le gritaba al encontrarlo “iAdiós, don Carranza!" ${ }^{\circ 6}$, él apresuraba el paso y no contestaba.

—iEh, don Carranza! —lo seguía la curiosidad.

Pero don Carranza - silueta baja y maciza en la noche... (p. 32) [la cursiva es mía]

El "don", "partícula que entraña afable respeto" (WALSH, 1957, p. 30), será la forma de tratamiento hasta el final del capítulo. Parece entonces que, a medida que se progresa en el relato, la escritura se va "contagiando" con la voz del entorno.

El trabajo de acercamiento al personaje y a su medio se ve también en el uso de los determinativos. En el párrafo que abre el capítulo, citado más arriba, aparece el demostrativo "esa" para referirse a la noche de la detención; "esa", sabemos, indica algo a medio camino entre "aquella" noche (cuando sucedieron los hechos) y "esta" noche (tiempo de la escritura); el mismo tipo de demostrativo acompaña al barrio, a la casa y al miedo: "imitando el fragor y el silbato de trenes que manejaban hombres como él, gente de esa barriada ferroviaria." (p. 32); "Cenaron todos juntos esa noche del 9 de junio en esa casa del barrio obrero de Boulogne." (p. 33); "Siempre ese temor de que lo agarraran una noche cualquiera..." (p. 33) [las cursivas son mías]. Pero, ya hacia el final del capítulo, en la recreación de un diálogo entre Nicolás Carranza y su mujer, se lee: "-_..Esta noche no duermo acá." (p. 34); indicando, con el estilo directo y el "esta", tal vez una adhesión definitiva al personaje.

Además, cuando el relato se refiere al hombre, a don Carranza, entonces el demostrativo es "este": "Y seguramente desde entonces asomó un brillo peligroso en la mirada de este hombre de rostro firme y despejado..." (p. 33), comenta el narrador después de relatar el episodio de la detención de Elena ${ }^{87}$, la hija mayor de Carranza. Se puede decir, entonces, que el uso del demostrativo "este" (y sus variantes de género y número) es una forma de traer al presente a las víctimas.

\footnotetext{
${ }^{86}$ En la primera y segundas ediciones se leía "iAdió, don Carranza!...", donde el "adió" imita el habla popular.

87 Lo mismo se observa referido a otros personajes: "Tiene dieciséis años este muchacho de mirada seria...." (p. 36) [se refiere al hijo de Garibotti]; "Tiene veintiún años este muchacho alto..." (p. 51) [se refiere a Carlos Lizaso, muerto en el fusilamiento]; "Este hombre —que más tarde se volcará al terrorismo y se hará llamar 'Marcelo'..." (p. 55); “Es una torre de hombre, este Vicente Damián Rodríguez..." (p. 71) [también muere en el fusilamiento].
} 
El narrador se fue aproximando al personaje (y lo fue acercando al lector, también) por diferentes caminos. Así, parece que el uso de los tiempos del pasado, aunque remiten al tiempo de la narración, género conocido y familiar para lector y narrador, se muestra insatisfactorio para relatar los hechos y es necesario actualizarlo de alguna forma ${ }^{88}$. Por eso este será el único capítulo de la primera parte referido enteramente en pasado. A partir de aquí, el relato estará en presente y las estrategias de aproximación (y persuasión) serán otras.

Así, en el capítulo siguiente, el foco estará puesto en la relación del protagonista con la casa y la familia. El capítulo se titula "Garibotti", y es sobre ese protagonista que esperamos leer. En cambio, después de una escueta información inicial, sabemos más de la decoración de las paredes, de la compañera y de los hijos que del propio Francisco Garibotti. Después, más adelante, sabremos que tiene seis hijos, que él también es empleado de ferrocarril, que toca la guitarra y que fue con Nicolás Carranza con quien se dirigió al lugar donde luego serán detenidos.

Francisco Garibotti es uno de los fusilados que muere en el basural; es de quien no "volveremos a tener referencias ciertas". Por eso, el narrador intentará llenar los vacíos de información, acercarse a esta víctima a través de lo que la rodea. El capítulo comienza con un comentario sobre la casa donde vive la familia y una descripción física del padre:

Casa de muchachones bravos y ambiente acaso tempestuoso ésta de los Garibotti, en el Barrio obrero de Boulogne. El padre, Francisco, era una estampa de hombre: alto, musculoso, cara cuadrada y enérgica, de ojos un poco hostiles, bigote fino que rebasa ampliamente las comisuras de los labios. (p. 35)

\footnotetext{
${ }^{88}$ Se puede pensar que haber elegido el pretérito genera un conflicto entre el tiempo en que tuvieron lugar los hechos y su actualidad inscripta en el tiempo de la escritura. Y eso se pone en evidencia en la oscilación de los demostrativos cuando se refieren al día de la detención: En el capítulo siguiente, "Garibotti" (para que no quede muy engorroso, aquí solo cito lo que aparece en el segundo capítulo. Se puede rastrear el mismo recurso en el capítulo siguiente, "Don Horacio"), escrito en presente, leemos: Esa tarde ha dejado [Garibotti] el servicio alrededor de las cinco... // Al padre le gusta tocar la guitarra y el muchacho canta. Es lo que hacen esa tarde. (p. 36) // Oscurece pronto estos días de junio, en pleno invierno. // Ya casi ha terminado de cenar Francisco Garibotti —un bife con huevos fritos comió esa noche _... // Presiente que al marido le ha entrado la comezón de salir esta noche de sábado... (p. 37). Entonces, además de un movimiento de aproximación a las personas y su entorno, aquí parece que el narrador está buscando un lugar en el tiempo desde el cual relatar los hechos.
} 
Observemos que en un único párrafo, están lado a lado la descripción del ambiente familiar y del padre: su presencia en los hijos está indicada — sin ningún conector causal - en la relación que se establece entre la cara enérgica y los ojos hostiles del padre y la imagen de "muchachones bravos" y el "ambiente acaso tempestuoso". El cuadro se completa en el segundo párrafo con los rasgos duros — boca, ojos - de la madre, acentuados por su actitud resuelta. Es como si formasen un todo cohesionado:

Hermosa mujer también la madre, aunque de rasgos duros y plebeyos. Alta, resuelta, de boca algo desdeñosa y ojos que no sonríen. (p. 35)

Las frases nominales — "Casa de muchachones..." y "Hermosa mujer..."- del primero y segundo párrafo transmiten un dinamismo que refuerza las ideas de energía y resolución asociadas a Francisco y Florinda. Pero también remiten al estilo de los titulares periodísticos, forma familiar para narrador y lector, en el que se omiten palabras que pueden ser recuperadas a partir de la gramática o del contexto ${ }^{89}$. Con ese recurso se realzan la información sobre el ambiente familiar y la madre —realce también intensificado por las inversiones sintácticas_- Es decir, se destacan quienes rodean a Francisco Garibotti.

Siempre en busca de aprehender alguna información y darle forma, a continuación el foco se dirige hacia la decoración de la casa y es a través de esta que viene la alusión a un pasado más lejano: "dentro de un marco amarillean remotas instantáneas de Francisco y Florinda — son jóvenes y se ríen en un parque..." (p. 35-36) [la cursiva es mía]; es poco, es apenas una referencia, pero está indicando que esa pareja tiene una historia personal, tal vez común, pero es su historia y las fotos en la pared son fragmentos de memoria.

En todo el capítulo, hay una abundancia de detalles aparentemente innecesarios, pero que le van dando forma y sustancia al personaje y su vida cotidiana:

\footnotetext{
${ }^{89}$ Esa forma está descripta en "La predicación: la predicación no copulativa. Las construcciones absolutas" de Hernández Carbó, Ma. Luisa y Suñer Gratacós, Avelina. En Bosque, Ignacio y Demonte, Violeta. Gramática descriptiva de la lengua española. Tomo II, Real Academia Española, Colección Nebrija y Bello. Madrid, Espasa Calpe, 2000.
} 
La pasión decorativa o recordatoria culmina en la prevista litografía de Gardel, recortado en negro, el sombrero casi tapándole la cara, el pie apoyado en una silla, pulsando la guitarra.

Pero es una casa limpia, sólida, discretamente amoblada, una casa donde puede vivir un obrero. Y "la empresa" les cobra menos de cien pesos de alquiler. (p. 36)

La elección del sustantivo "pasión" aplicado a la idea de decoración o recordación — se podría haber usado simplemente "afición" - contrapuesto al adjetivo "prevista", le dan al comentario un tono un tanto irónico. El "pero" con el que empieza el párrafo siguiente refuerza lo anterior: como si una casa en la que se manifiesta "la pasión decorativa..." no pudiese ser limpia, sólida, apta para que viva un obrero. Por un lado, puede ser una forma irónica que remite a la perspectiva de la clase media: "pobre, pero honrado". Por otro, podemos encontrar una pista para entender el "pero" un poco más adelante, cuando leemos que Francisco Garibotti: no quiere "meterse en líos" gremiales ${ }^{90}$. Esta afirmación surge cuando ya sabemos que la pareja tiene seis hijos, cómo es la casa y que Garibotti es obrero. Así, queda claro que el narrador entiende los motivos de las indecisiones de este personaje, pero parece que no termina de aprobarlos.

Aun así, en este capítulo como en el anterior, en el discurso del narrador se filtrará el habla de sus interlocutores. Habrá mezcla de palabras o expresiones de uso habitual o coloquial con las de origen culto: "Delia Beatriz, de nueve, mitiga un poco ese ambiente cerradamente varonil. Morena, de flequillo, ojos risueños, el padre se ablanda frente a ella" (p. 35) [la cursiva es mía]. "Mitigar" y "ablandar" son prácticamente sinónimos, solo que el primero es de uso menos corriente que el segundo, que es más coloquial.

Si en el capítulo anterior la inversión sintáctica era usada solo una vez para destacar la elección política de Carranza - "Era peronista Nicolás Carranza" (p. 32) - y el resto para hacer referencia a los hijos — "Seis hijos tenía Nicolás Carranza” (p. 31), “...toda una escalera de pibes tenía don Carranza" (p. 32), etc.-; aquí, ponen de manifiesto otros aspectos comunes de la vida diaria: "Treinta y ocho años tiene Garibotti...", "Tiene dieciséis años este muchacho de mirada seria..." (p. 36), "...un bife con huevos fritos

\footnotetext{
${ }^{90}$ En la primera edición, al término del primer párrafo dice: "Que no le hablen a él de política ni de líos gremiales. Ya bastante le cuesta mantener a ese rosario de hijos que tiene." (WALSH, 1957, p. 24)
} 
comió esa noche..." (p. 37). En definitiva, en ambos casos, lo principal no es la militancia política de los protagonistas lo que interesa destacar, sino su vida cotidiana.

Con este capítulo se cierra un primer bloque. Carranza y Garibotti son vecinos y no viven en el barrio donde fueron detenidos. Son los que llegaron de más lejos. El capítulo termina con los dos hombres internándose "por [el] largo pasillo" del lugar donde serán detenidos y el narrador anuncia:

De Garibotti no volveremos a tener referencias ciertas. Para que alguna recojamos de Carranza antes del silencio definitivo, tendrán que pasar muchas horas.

Y muchas cosas incomprensibles. (p. 39)

\section{La clase media}

En los dos capítulos siguientes, la construcción del retrato de la vida cotidiana estará presidida por la descripción del barrio y el día a día de sus habitantes. Si en "Carranza", el narrador usaba algunas metonimias para hablar de los chicos - "coro de voces chillonas" (p. 31), "lo seguía la curiosidad" (p. 32)—, el tercer capítulo, "Don Horacio", parece una gran metonimia no solo de Horacio Di Chiano, sino también de todas las víctimas que viven en el barrio en el cual son detenidas; como veremos, a pesar del título, buena parte de esta sección está dedicada a la descripción de la localidad de Florida, del barrio y de las casas en las que se llevará a cabo la detención de los protagonistas.

El capítulo se divide en tres momentos: comienza con un comentario general sobre Florida; a continuación hay una somera descripción de Don Horacio, su casa, y sus actividades cotidianas y las del 9 de junio; finaliza con la noticia del levantamiento que se está produciendo en Campo de Mayo. Esta parte es diferente de las dos anteriores tanto por las características de Don Horacio y los habitantes de la localidad de Florida — "clase media apacible y satisfecha" (p. 43) — como por el hecho de que Don Horacio es una de las víctimas que se salva. 
Lo repetido de la cotidianeidad, aquí, está en el propio demorarse de la descripción; en el párrafo que abre el capítulo leemos:

Florida, sobre el ferrocarril Belgrano, está a veinticuatro minutos de Retiro ${ }^{91}$. No es lo mejor del partido de Vicente López, pero tampoco es lo peor. El municipio regatea el agua y las obras sanitarias, hay baches en los pavimentos, faltan letreros indicadores en las esquinas, pero el pueblo vive a pesar de todo. ( $p$. 41)

Observemos que la idea "no es lo mejor" está explicada, justificada y repetida en la enumeración de las características del municipio; lo mismo acontece con "tampoco es lo peor" ya que el pueblo "vive a pesar de todo".

Los dos párrafos siguientes dedicados tanto al barrio como a los vecinos que viven en él, siguen haciendo hincapié en los contrastes propios "de las zonas [en] desarrollo"; a continuación, a modo de conclusión hay un párrafo más: "La vida es tranquila, sin altibajos. Aquí, en realidad, nunca ocurre nada." (p. 42). Parecería que el relato después de esta contextualización espacial, va a seguir adelante, pero no, todavía hay un párrafo más en el que se vuelve a discurrir sobre la falta de obras públicas y la cordialidad de los vecinos - “Las esquinas están mal iluminadas y hay que cruzarlas con precaución [...] Donde hay un puentecito o una hilera de piedras para facilitar el cruce, es obra de los vecinos." (p. 42) - Este volver sobre lo mismo apunta nuevamente a lo reiterativo de la cotidianeidad pero, sobre todo, parecería que se dilata el momento de empezar a narrar la ruptura.

Así, a la descripción del barrio todavía le sigue la de la casa en la cual han entrado Carranza y Garibotti y, de allí, al estrecho pasillo "limitado a la derecha por una pared medianera y a la izquierda por un alto cerco de ligustrina." (p. 42).

Después de esa larga mediación ${ }^{92}$, en el párrafo siguiente finalmente tendremos la primera información sobre Don Horacio:

\footnotetext{
${ }^{91}$ Retiro es una estación terminal de trenes, que queda en Capital Federal.

92 En la primera edición de Operación Masacre, que apareció en la revista Mayoría, el título del capítulo era "Dos casitas de Florida" (WALSH, 1957a). Pero, tanto en aquel texto como aquí, se le dedican solo dos párrafos a las "casitas" en los cuales lo que se describe es el exterior y el pasillo. Tal vez se pueda pensar
} 
El departamento del fondo está alquilado a un hombre sobre quien volveremos a último momento. En el del frente vive con su familia el dueño de toda la finca, don Horacio di Chiano. (p. 42)

Las dos oraciones de la cita se refieren a los habitantes de los departamentos: la primera anuncia algo que será desarrollado más adelante; en la otra, el nombre de don Horacio aparece al final, pero se destaca por el lugar que ocupa. Después de la descripción del barrio y sus habitantes, saber que don Horacio es dueño de todo el terreno y que vive con la familia es una forma de destacar la clase social a la cual pertenece este protagonista. Esa característica será reforzada en los párrafos siguientes, en los cuales el narrador describe y comenta, ordenadamente, el aspecto físico de don Horacio, su ocupación, sus anhelos para el futuro y algunos detalles de la casa:

Su casa trasciende clase media apacible y satisfecha. Desde los muebles de serie hasta los platos ornamentales que en las paredes reiteran distraídas sentencias - "Errar es humano, perdonar es divino" - o alguna audacia ingenua - "El amor hace pasar el tiempo, el tiempo hace pasar el amor"-, hasta la imagen devota que ha colocado en un rincón la esposa, o la única hija, Nélida, silenciosa muchacha de veinticuatro años. Lo único notable es cierta abundancia de cortinados, de almohadones, de alfombras. La señora Pilar — cabello blanco y modales apacibles - es tapicera. (p. 43)

La enumeración pone en un mismo nivel muebles, platos, imagen devota y a Nélida, única hija; a los cortinados y a la señora Pilar. La clave para interpretar esta igualación está en la característica del "habitante medio del barrio" quien "bajo cualquier gobierno protesta sin exaltarse contra el alza de la vida y los transportes imposibles." (p. 42). De esta manera, los elementos que la descripción resalta y la forma de colocarlos refuerzan la idea de que este tipo de ciudadano, de "clase media apacible y satisfecha", no hace revoluciones ${ }^{93}$.

en la oscilación del narrador que desaparece en función de una mayor similitud entre los capítulos, como principio de coherencia.

${ }^{93}$ Hasta la tercera edición, este mismo párrafo continuaba diciendo: "En esta precisa enumeración de cualidades y triviales virtudes se agota todo el misterio. Nada más extemporáneo aquí que la idea de revolución o de violencia... Las ideas políticas del propio don Horacio son tan imprecisas o fluctuantes, que apenas si vale la pena mencionarlas. Durante el régimen anterior se le conoció como 'antiperonista' en los medios donde podía manifestarse. En setiembre fué (sic) 'revolucionario'. Más tarde es posible que se haya trocado en 'anti-revolucionario'. Simples posturas verbales, desde luego, pues nunca estuvo afiliado a ningún partido ni actuó en política." (WALSH, 1957, p. 28). En general, en los cambios que se producen entre ediciones de Operación masacre (sobre todo entre la primera y segunda) hay una disminución de las 
Siempre con la idea de clase media satisfecha, el narrador describe el sábado de don Horacio: ha estado de guardia en su empleo de electricista y, alrededor de las nueve de la noche, toma un tren -como siempre- para volver a su casa y en el trayecto lee el periódico: "Nada hay de nuevo en esta rutina. Es la misma de años y años." (p. 43).

El tono "cordial" del capítulo y la insistencia sobre lo apacible de la vida de la clase media, podrían hacernos pensar que para don Horacio las cosas fueron fáciles esa noche. Realmente, parecería que la posición del narrador es de constatación. De esta manera, cuando leemos en la segunda parte de Operación masacre "El tiempo se detiene", que entre otras cosas, trata sobre el tiro de gracia dado a don Horacio, la sensación de ruptura se intensifica; la noción de una violencia absurda e innecesaria se hace más patente.

Los rodeos para referirse a la detención (y a la violencia en general) hacen pensar en la búsqueda de una forma adecuada para nombrarlo: "El barrio en el que van a ocurrir tantas cosas imprevistas..." (p. 41), "La casa donde [...] se desarrollará el primer acto del drama y a la que volverá por último un fantasmal testigo" (p. 42) [la cursiva es mía]. Es verdad que se trata de "cosas" elaborada para un narrador que tiene la precisión y la poesía que demuestra en los dos primeros capítulos; lo mismo se puede decir de la elección de la palabra "drama". "Cosas imprevisibles", "primer acto del drama", "fantasmal testigo", colocados como están parecen mucho menos efectivos que toda la organización del primer capítulo. De alguna manera es como si el narrador, al crear extrañamiento, estuviese llamando la atención sobre su trabajo, anunciando algo imprevisible, que excede las expectativas.

Esta manera de anunciar los hechos, usando clisés, se repetirá hasta el final. Son fórmulas típicas de las crónicas policiales que le imprimen un quiebre, una ruptura, desde el punto de vista lexical, a la forma del relato; es como si el narrador estuviese indicando la dificultad de nombrar la violencia, de poetizarla, de representarla con una cierta

\footnotetext{
interferencias — de los juicios — del narrador y una elección: reducir el espacio de explicaciones; parecería una estrategia tanto para lograr una mayor aproximación al lector, como para no crear mayores distanciamientos entre grupos o clases sociales.

${ }_{94}$ El Diccionario de la Real Academia Española la define como: "Todo lo que tiene entidad, ya sea corporal o espiritual, natural o artificial, real o abstracta."
} 
armonía o con una belleza que no tiene; todas las veces se siente un extrañamiento estético frente a esa forma de nombrarla.

Al llegar a su casa, don Horacio se encuentra de casualidad con otro vecino, Miguel Ángel Giunta, a quien invita a escuchar la pelea después de cenar; los invita a él y a la esposa. El carácter familiar del encuentro se acentúa cuando leemos que Miguel Ángel Giunta — vendedor en una zapatería - esa tarde, cuando encuentra a Don Horacio, está volviendo de casa de sus padres.

Si hasta aquí la sensación de injusticia, de la desproporción del castigo, se iba construyendo a partir de la descripción de la vida cotidiana de las víctimas, ahora el narrador no duda en postular sus propias percepciones como prueba:

...lo que en el acto se desprende de él es una impresión de honradez sólida, de sinceridad. De todos los testigos que sobrevivan al drama, ninguno resultará tan convincente, a ninguno le resultará tan fácil y natural evidenciar su inocencia, mostrarla concreta y casi tangible. Bastará hablar una hora con él, oírle recordar, ver la indignación y el evocado espanto que paulatinamente le brotan de adentro, le asoman a los ojos y hasta le erizan el cabello para deponer toda incredulidad. (p. 47)

En este pasaje — que por su forma recuerda el género de opinión en el cual el periodista enuncia su juicio personal y subjetivo_-, a diferencia de los capítulos anteriores, la enumeración y la reiteración sirven para resaltar la sensación que tiene el narrador sobre la honradez de Giunta. En principio, la legitimidad que se autoatribuye el narrador parece un recurso no muy convincente. Bien mirado, es otra forma de generar extrañamiento que obliga al lector a hacer el ejercicio de recordar de dónde viene la "autoridad" del narrador; a preguntarse por qué el narrador, de repente, interviene de esa manera.

Además, también obliga, en el oficio de lector, a armar el propio "relato"; a hacer un trabajo de asociación cuidadoso. Se trata de un capítulo casi sin referencias contextuales a no ser por dos que lo enmarcan:

Giunta, o don Lito, como lo llaman en el barrio, vuelve de Villa Martelli, donde ha pasado la tarde con los padres. (p. 47) [se lee al principio del capítulo] 
No sospecha - mientras cena en esa casa apacible, adquirida con su esfuerzo, rodeado del afecto de los suyos... (p. 48) [dice al final]

Por un lado, sabemos del final del capítulo tres que Giunta vive en el mismo barrio que don Horacio; por otro, el adjetivo "apacible" nos recuerda que Miguel Ángel Giunta pertenece a la misma "clase media apacible y satisfecha" que vive en Florida. Otro dato que puede pasar desapercibido es el "don" de la primera cita, que implica "afable respeto", como consta en la primera edición de Operación masacre (WALSH, 1957, p. 30). Esa única partícula resume en sí la relación de Giunta con el barrio y muestra la destreza en el oficio del narrador. La misma destreza del personaje haciendo uso de sus "cualidades menores".

Todavía pensando sobre esta elección del narrador - la de usar sus propias impresiones como prueba y llevar al lector a "completar" la información_, puede ser útil remitirnos a la primera edición de Operación masacre. Allí el capítulo consta de cinco párrafos, y las opiniones del narrador están enmarcadas por la descripción de la relación familiar y barrial. Transcribo, a modo de ejemplo, el párrafo que abre el capítulo:

Giunta, o don Lito como lo llaman en el barrio — donde el nombre de pila o el sobrenombre, precedidos de la partícula que entraña afable respeto, sustituyen en el tratamiento diario al apellido [...] - vuelve de Villa Martelli, donde ha pasado la tarde en la casa paterna. La visita es casi una rutina en esa familia sólidamente unida. Ha conversado con el padre, un italiano menudo, canoso [...] También con la madre, bonachona y un poco ausente. Cuando vuelve, encuentra a su mujer bastante mejorada. Ella es joven como él, silenciosa y apegada al hogar. Tiene una chiquilla de cortos años, con quien juega ahora ruidosamente el padre. (WALSH, 1957, p. 30) [la cursiva es mía]

La información suprimida a partir de la segunda edición es del mismo tipo de la que aparecerá en los capítulos siguientes: datos físicos y de carácter de padres, madres, esposas o hijos. Con la eliminación de esa información se refuerza el paralelismo entre este capítulo y los anteriores y se marca una diferencia con los posteriores, por lo menos con el bloque de los "conspiradores", reforzando en la forma el grado diferente de información o compromiso en relación a la revolución que se estaba gestando. 


\section{Los "conspiradores"}

Hasta aquí fueron presentados cuatro personajes: dos de ellos, los que se encuentran en la calle de casualidad, pertenecen a la clase media; de los otros dos sabemos que uno es peronista y perseguido por distribuir "unos" panfletos (p. 33) y que el otro salió de mala gana con su amigo Carranza (p. 37).

El grupo de protagonistas integrado por Lizaso, Marcelo, Gavino y Torres, presentados en los capítulos centrales, sabe sobre (o está involucrado en) la revolución de Valle. Para cada uno de estos, el narrador buscará hechos personales o biográficos que justifiquen lo que él considera, en 1957, la participación en actos de terrorismo y violencia. Esta priorización de lo subjetivo parece diluir lo que concierne a la efectiva conciencia militante de los "conspiradores", lo cual puede interpretarse como una estrategia de persuasión movida por el convencimiento del narrador de que el Estado, o sus instituciones, no tenían el derecho a inflingir un castigo tan desproporcionado como fue el fusilamiento ${ }^{95}$. Así, con el relato de dichos episodios el movimiento del narrador es doble: si por un lado, el narrador va construyendo para sí una explicación para las elecciones políticas de los protagonistas; por otro, va demostrando que la violencia policial fue desmedida $-\mathrm{y}$ que es esa misma desmesura la que engendra más violencia-; recordemos las palabras del narrador en la introducción a la primera edición:

Más que nada temo el momento en que humillados y ofendidos empiecen a tener razón. Razón doctrinaria, amén de la razón sentimental o humana que ya les asiste [...] Y ese momento está próximo y llegará fatalmente, si se insiste en la desatinada política de revancha que se ha dirigido sobre todo contra los sectores obreros. La represión del peronismo, tal como ha sido encarada, no hace más que justificarlo a posteriori. (p. 264)

\footnotetext{
${ }^{95}$ Esta actitud del narrador no está dictada por una psicología tranquilizadora, como denomina Carlos Mangone a la actitud de una parte de la "clase" política argentina sobre el tema de los desaparecidos durante la última dictadura militar (1976-1983). Dice Mangone que por un tiempo "para la sociedad civil los desaparecidos habían sido objeto de arbitrariedad (porque no 'tenían nada que ver' o porque no habían sido juzgados). Solo algunos organismos de derechos humanos [...] reivindicaban la estrecha relación entre la represión y la actividad de los desaparecidos y asesinados." (MANGONE, 2000, p. 9).
} 
Esta secuencia de "conspiradores" comienza con Rogelio Días, una de las víctimas que sobrevive. El autor nunca pudo hablar con este sobreviviente, ni con nadie cercano a él ${ }^{96}$. Tampoco aparece como una figura clara para las personas que estaban aquella noche en el departamento de la detención. Ante lo difuso de las informaciones, ante los saberes incompletos y fragmentados, el tejido narrativo se irá construyendo con cada indicio $-\mathrm{y}$, a veces, hasta con acumulación de información aparentemente "innecesaria" para intentar cercar lo desconocido_ que pueda ayudar a formar una idea más cabal.

Aún así, la imprecisión se filtrará en la narrativa. El primer párrafo es de contextualización y avanza hacia los hechos: "Al departamento del fondo, entretanto, van llegando algunas personas" (p. 49). En la segunda oración del capítulo leemos:

En un momento habrá alrededor de quince hombres jugando a los naipes en torno a dos mesas, escuchando la radio o conversando. (p. 49).

Por un lado, aunque en una primera lectura no lo sepamos, el dato de las "dos mesas" en ningún momento será retomado ${ }^{97}$; es como si el narrador quisiese registrar todo, lo más posible, para hacer la información menos difusa.

Por otro lado, la sintaxis de esa oración da a entender que, en el mismo momento, los quince hombres jugaban a las cartas en torno a las dos mesas; "escuchando la radio o conversando" parecería que pierde la referencia. Como lectores, tenemos que colaborar con el narrador, entendiendo que había quince hombres de los cuales algunos jugaban y otros escuchaban la radio o conversaban.

La misma sensación de imprecisión se desprende de lo que "sabemos" y lo que "no sabemos" en relación a Rogelio Días:

\footnotetext{
${ }^{96}$ Lo incluyo en esta sección, aunque no quede claro si sabía o no del alzamiento, pues como dice el narrador, "son muchos en el Gran Buenos Aires los que están en la onda" (p. 68), también porque pertenecía al ejército y su actitud durante la detención - "roncará apacible y estruendosamente en un banco de la Unidad Regional San Martín" (p. 50) - es semejante a la de Troxler, otro sobreviviente, que había sido de la policía. En otro orden de cosas, el hecho de que durmiese tranquilamente hace más nítida la idea de lo inesperado del fusilamiento.

${ }^{97}$ Si leyésemos Operación masacre en clave de novela policial, podría pensarse en los indicios que desvían la atención con otra intencionalidad.
} 
Lo único preciso, lo único en que coinciden quienes recuerdan haberlo visto, es su aspecto físico, un hombre corpulento, provinciano, muy moreno, de edad indefinible ("usted sabe que a los negros es difícil conocerles la edad..."), alegre conversador, que en un momento estará jugando con entusiasmo al chinchón, y en un momento muy distinto — cuando ya todos temen-roncará apacible y estruendosamente en un banco de la unidad regional San Martín, como si no tuviera el más leve peso en su conciencia. En estas dos instantáneas puede resumirse toda la vida de un hombre. (p. 50) [la cursiva es mía]

Todos los que vieron a Rogelio Días coinciden en sus observaciones sobre el aspecto físico, dice el narrador. Sin embargo, "provinciano", "alegre conversador", jugar y roncar no pertenecen al campo de lo físico. Así, lo difuso, lo borroso contra lo que lucha el narrador, también se filtra aquí por más que use los mismos recursos (reiteración y acumulación) que antes para cercar la desinformación. Obsérvese también, que el hecho de que el narrador haga caber "toda la vida de un hombre" en "dos instantáneas" es una forma de imponer la micro narrativa a la escasez en la construcción el personaje ${ }^{98}$.

En dicha construcción la forma en que se superponen los tiempos refuerza la sensación de imprecisión. El relato está hecho con el foco narrativo en la noche de la detención y en el tiempo de la investigación y escritura del crimen:

Al departamento del fondo, entretanto, van llegando algunas personas [...] Algunos se irán y vendrán otros [...]

Sabemos [...] que alrededor de las 21 aparece un hombre llamado Rogelio Días, pero no sabemos con exactitud quién lo trae ni a qué viene. (p. 49)

En la primera cita, la perífrasis - "van llegando" - y el verbo "venir" indican que se trata de la noche de la detención. Ambos elementos también apuntan un movimiento del narrador: es como si él mismo fuese uno de los que va llegando: comienza mirando hacia el departamento y luego está dentro del mismo — "vendrán"-. En la segunda cita, por el contrario, el verbo "saber", en presente, parece referirse al tiempo de la investigación / escritura; pero, al igual que en la oración anterior, los verbos "traer" y "venir" indican el lugar desde el cual se hace el relato (el departamento).

\footnotetext{
${ }^{98}$ G. Pampillo y M. Urtasun consideran que es una forma de cuestionar el género biografía. "Operación masacre y las estrategias de persuasión". (LAFFORGUE, 2000).
} 
La nota al pie de página que acompaña el capítulo puede pensarse como un recurso más para completar la historia que podría darle consistencia al personaje. Allí, el narrador hace un pequeño resumen desde que se levanta la hipótesis de la "existencia y supervivencia" de Rogelio Días hasta obtener datos más precisos. El relato está acompañado por la referencia a los diferentes momentos de publicación y la escritura integra la materia narrativa:

Cuando mencioné por primera vez a Díaz en mis notas para Revolución Nacional su existencia y supervivencia eran más bien una hipótesis, pude luego comprobar...

...Mientras se publicaba este libro en la revista Mayoría, recogí los siguientes datos...(p. 78)

Observemos que aquí, la voz del narrador asume o se aproxima a la del autor: cambia el "nosotros" por la primera persona; la repetición y enumeración por una descripción más directa. Todos estos aspectos, si bien recuerdan la forma de los textos informativos, no dejan de señalar la tensión que se establece entre realidad y ficción.

Al contrario de Rogelio Días, la figura de Carlos Lizaso es "Más nítida, más apremiante, más trágica..."; Carlos Lizaso es otra de las víctimas que muere en el fusilamiento y que está enterada de la revolución que se avecina. Pero esto último lo sabremos al final del capítulo. Primero estarán los vestigios, las insinuaciones sobre la muerte. Si en "Carranza" sabíamos desde el principio que el protagonista estaba muerto, aquí en cambio hay que deducirlo a partir de otras pistas. Parecería una especie de pudor del narrador que no alude directamente a la muerte y que en los rodeos crea ambigüedades que solo serán resueltas, más o menos, al final del capítulo.

En el primer párrafo se reconocen estrategias narrativas usadas anteriormente en Operación masacre: reiteración, enumeración, inversión sintáctica:

Más nítida, más apremiante, más trágica, aparece la imagen de Carlitos Lizaso. Tiene veintiún años este muchacho alto, delgado, pálido, de carácter retraído y casi tímido. Pertenece a una familia numerosa de Vicente López. (p. 51) 
"Más nítida" funciona como elemento de cohesión en relación al capítulo anterior, donde leíamos: "Hasta la identidad de uno o dos de los protagonistas quedará finalmente borrosa o ignorada." (p. 49). Así, podríamos pensar que Carlos Lizaso está vivo y que el autor pudo entrar en contacto con él. Sin embargo, "más apremiante" (en su sentido de urgencia o de opresión) junto con "más trágica" pueden empezar a dar pistas sobre el fin que llevó la vida de ese chico; pero el presente en "tiene" y "pertenece" dejan en suspenso la respuesta hasta la oración que cierra el capítulo: "Pero todo saldrá mal." (p. $53)$.

Antes de ese final, y de seguir adelante sobre la figura de Carlitos Lizaso, el foco del narrador se desplaza hacia don Pedro, el padre de Carlos, y sus cambios políticos a lo largo de los años: fue radical ${ }^{99}$ y después simpatizante peronista; para cuando llega el golpe de 1955 (contra Perón), don Pedro Lizaso ya "Es prácticamente un opositor" (p. 51) del peronismo. Como tantos otros, don Pedro era de los que esperaban que con el golpe de 1955 todo cambiase, "que se conservaría lo bueno que hubiera quedado y se destruiría lo malo [...] Pero después..." (p. 51), dice un amigo de don Pedro y agrega el narrador: "Después ya se sabe lo que ocurre. Una ola revanchista sacude al país. Don Pedro Lizaso, envejecido, enfermo y desilusionado, vuelve a ser opositor." ${ }^{100}$ (p. 51).

Las diferentes opciones políticas de don Pedro son usadas por el narrador para explicar las opciones de los hijos: "Estos cambios se reflejan en sus hijos varones" (p. 52). De esa forma, cuando llegamos al final del capítulo y conocemos que Carlos estaba enterado y a favor del levantamiento de junio, ya fuimos construyendo la imagen de un chico que sigue los pasos del padre; además, ya tenemos algunos indicios para suponer que está muerto. Pero aun así, el narrador no se refiere a una elección política:

\footnotetext{
${ }^{99}$ De la Unión Cívica Radical, partido que gobernó el país entre 1916 y 1930.

${ }^{100}$ En la primera edición de Operación masacre, el narrador se extiende sobre lo que significó el golpe de 1955 para los que lo recibieron con esperanzas: "Después se hizo todo lo contrario. Después las cosas no salieron como lo esperaba la inmensa mayoría del país, deseosos [sic] de paz y de concordia. Después se invirtió el signo, pero las tropelías continuaron. Ya no se apaleó a estudiantes, pero se apaleó a obreros. Y la opresión ideológica, insufrible en la última época del peronismo, alcanzó su más perfecto símbolo en el decreto 4.161" (WALSH, 1957, p. 33). Ese decreto es el que prohibía "La utilización [...] de las imágenes, símbolos, signos, expresiones significativas, doctrinas artículos y obras artísticas, que pretendan tal carácter o pudieran ser tenidas por alguien como tales pertenecientes o empleados por los individuos representativos u organismos del Peronismo". (Boletín oficial 9/3/1956; http://www.lucheyvuelve.com.ar )
} 
Adivinamos su actitud mental ante el proceso político. Un detalle lo confirma. Después que él se marcha, su novia encuentra en su casa un papel escrito con letra de Carlos: "Si todo sale bien esta noche...". (p. 53) [la cursiva es mía]

Observemos el eufemismo aquí usado para referir la opción de Carlos: "actitud mental". Así, podría decirse que la referencia a la historia no solo sirve aquí como contextualización, sino también como una justificación -ante los lectores y ante el propio narrador — para la "actitud mental" de Carlos.

Para interpretar estas estrategias del narrador hay que tener en cuenta quiénes eran, en 1957, los posibles interlocutores _intelectuales y público en general antiperonista ${ }^{101}$ Por otro lado, y considerando que el autor no era peronista en aquel momento, parece ser una estrategia para no estimular atribuciones de culpas; no es eso lo que está en pauta, y sí algo más atroz que es la desmesura del castigo que sufrieron esas personas.

Como veremos, en los próximos tres capítulos — "Alarmas y presentimientos", "Gavino” y "Explicaciones en una embajada" — la estrategia para "diluir" las responsabilidades de los participantes tomará diferentes formas, así como también la manera de aproximación a los sobrevivientes, todos ellos enterados o de alguna forma involucrados en el alzamiento. Por esto mismo, se produce un cambio de perspectiva; hay una especie de señalamiento o explicitación de las fuentes de información de las que proviene la mirada del narrador; hay también referencias a un tiempo posterior a la masacre, expresado por la forma en futuro. Todos parecen recursos de legitimación de la voz del narrador frente a los interlocutores, incluidos los propios sobrevivientes.

Los tres capítulos hacen referencia directa a los hechos que relata Operación masacre. Los dos primeros traen escenas de momentos anteriores a la detención; el último, conversaciones entre el narrador y uno de los sobrevivientes, asilado en una embajada, meses después del fusilamiento.

"Alarmas y presentimientos" funciona como una especie de bisagra entre los capítulos anteriores y los próximos. Por un lado, presenta a otro protagonista, que se hace llamar "Marcelo", que con su preocupación en relación a Lizaso anuncia el peligro que se

\footnotetext{
${ }^{101}$ Ver la "Introducción” de la primera edición (WALSH, 1957).
} 
avecina; por otro, hay un progreso en el relato: es la primera vez que se hace alusión al levantamiento desde los propios involucrados.

"Marcelo" es presentado con dos informaciones fundamentales: la primera dice que, con el tiempo se hará "terrorista"; la segunda, que está enterado del levantamiento. Ambas están a continuación del primer párrafo que muestra su preocupación en relación a la vida de Carlos Lizaso: "Una, dos, tres veces pasará por la casa para buscar a Lizaso, para llevárselo, para arrancarlo a la muerte..." (p. 55):

\begin{abstract}
Este hombre -que más tarde se volcará al terrorismo y se hará llamar "Marcelo"- representa un curioso papel en los acontecimientos. Es amigo de la familia Lizaso y de otros protagonistas. Por Carlitos siente una paternal solicitud, un cariño que el tiempo y la desgracia tornarán amargo. Este hombre sabe lo que está ocurriendo. De ahí que tema, que quiera llevarse el muchacho. Pero siempre lo encontrará entretenido, animado, conversando, y se dejará disuadir por la repetida promesa. (p. 55) [la cursiva es mía]
\end{abstract}

El lugar que ocupan ambas informaciones nos predispone a la simpatía: entre la idea de amistad, de temor y cariño paternal, de amargura. Además, las dos están diluidas entre otras informaciones incompletas: ¿qué curioso papel es ese? ¿de qué otros protagonistas es amigo? ¿por qué el cariño se tornará amargo? $\mathrm{Y}$, finalmente, ¿por qué se volcará al terrorismo ${ }^{102}$ ? A pesar de todas las incógnitas, el foco del narrador vuelve inmediatamente a la escena dentro del departamento.

El capítulo termina con la recreación de un diálogo entre "Marcelo" y un interlocutor que, sabremos en la sección siguiente, se trata de Norberto Gavino, otro de los detenidos la noche del 9 de junio.

\footnotetext{
102 La respuesta para algunas de esas interrogaciones, solo aparecerá más adelante, para el lector de la edición definitiva (pp. 273-281); pero mucha de esa información no consta en la segunda, tercera y cuarta ediciones. Por ejemplo, en relación al "curioso papel" se puede intuir que Marcelo evoca, en la trama de Operación masacre, al mensajero que anuncia la desgracia en la tragedia. Intuición que se confirma si nos remitimos a la primera edición en libro de Operación masacre: "Este hombre -lo llamaremos M.representa un curioso papel en los acontecimientos. En cierto modo, el papel del coro en la tragedia, que lo sabe todo, lo adivina todo y nada puede impedir." (WALSH, 1957, p. 35). La alusión al coro de la tragedia desaparece a partir de la segunda edición, cuando el autor ya había empezado a comprender que no habría reparación para el crimen, que "los muertos bien muertos, y los asesinos probados, pero sueltos." (p. 297). Esta supresión parece coherente pues si en la tragedia clásica, la exclusión del héroe devuelve la comunidad al equilibrio perdido en el acto trágico, no es lo que sucede en Operación masacre.
} 
A diferencia de los capítulos anteriores, en los que las palabras y hasta la sintaxis de las personas se mezclaban con las del narrador, aquí se las cita entre comillas o cursiva. El capítulo comienza con las mismas palabras con las que acabó la parte anterior:

"Ya no hay nada esta noche", repite Norberto Gavino para sus adentros. Hace rato que la radio tendría que haber dado la noticia. Por un momento piensa que "Marcelo" tiene razón. Pero después se olvida. Si no hay nada, tampoco hay peligro para nadie. Muchos han venido simplemente de visita, gente a quien él ni conoce, sería ridículo decirles: "váyanse, estoy por hacer una revolución".

Porque no hay duda de que Gavino, aunque a estas horas se encuentre desconectado y no sepa a qué atenerse, está en el levantamiento. (p. 57)

Tanto el "la" (en "la noticia") como el "está" ("en el levantamiento"), en cursiva, parecen acentuar una especie de familiaridad y complicidad; en primer lugar, porque no es cualquier noticia, sino la del levantamiento; después, porque el "está" recuerda una forma de hablar coloquial ("está en la cosa..."), en lugar de "sabe del" o "forma parte del".

Otro aspecto que se puede observar es la explicación y afirmación, "porque no hay duda...", con que comienza el segundo párrafo; parece que el narrador está justificando la cita "Váyanse, estoy por hacer una revolución.". Un indicio para entender ese comienzo de párrafo está en la nota al pie de página, que figura a partir de la segunda edición de Operación masacre, en la que dice:

A mediados de 1958, Gavino me escribió desde Bolivia para manifestar su disconformidad con el breve retrato que trazo de él, y cuya fuente son otros testigos. (p. 78) [la cursiva es mía].

Como vemos, aunque el narrador reafirma su opción, también la justifica haciendo referencia a las fuentes que, aunque no se especifiquen, podemos suponer "externas" al relato. Con la cita entre comillas y la nota al pie de página se hace explícita la tensión entre ficción y realidad que se cierne sobre toda la narración y particularmente en la propia forma de este capítulo.

Aún pensando en dicha tensión, si nos remitimos a la primera edición del libro, allí se lee: 
...Muchos han venido simplemente de visita [...], sería ridículo decirles: "Váyanse, estoy por hacer una revolución".

Porque no hay duda de que Gavino, aunque a estas horas se encuentre desconectado y no sepa a qué atenerse, está en el levantamiento.

Cuáles son los elementos que me permiten suponerlo, desde luego no lo voy a decir. Primero, porque no es mi función. Segundo, porque él podría tranquilamente sostener que esto es una novela. $Y$ tercero, porque sin convertirme en juez, estoy convencido de que cualquiera haya sido su culpa, la pagó con una experiencia de terror que a muy pocos hombres es deparada, y que hasta en su caso era brutalmente injusta. (WALSH, 1957, p. 36)

Aunque todo el párrafo es suprimido a partir de la segunda edición, nos puede dar algunos indicios de lo que guió la construcción de Operación masacre. Observemos que el segundo motivo señala la conciencia del narrador de que la forma elegida para hacer el relato de los hechos remite a la literatura ${ }^{103}$. En relación a la afirmación contenida en el tercer motivo, se puede decir que, además de ser la que dicta la forma de Operación masacre, da pistas sobre la reescritura. En esta lo que se observa es una disminución de las interferencias del narrador; este hace menos explícitas opiniones y explicaciones que podrían inducir atribuciones de "culpas".

El último capítulo de este bloque, "Explicaciones en una embajada", gira alrededor de charlas que el autor mantuvo con uno de los involucrados, Juan Carlos Torres, "personaje que explica gran parte de la tragedia" (p. 59). Como en el capítulo anterior, aquí quedan explícitas las fuentes de información o los diferentes puntos de vista sobre Juan Carlos Torres: el del "dueño de casa", Don Horacio; el del vecindario, el de la policía. Además de estas miradas, también está la del narrador:

Yo lo encontré, por fin, muchos meses más tarde, asilado en una embajada latinoamericana, caminando de un lado para otro en su forzoso encierro, fumando y contemplando a través de un ventanal la ciudad tan próxima y tan inaccesible. Volví a verlo varias veces. Alto y flaco, de abundante cabellera negra, nariz aguileña, ojos oscuros y penetrantes, me impresionó aun allí

\footnotetext{
${ }^{103}$ Aunque, como ya dije, el trabajo que estoy desarrollando aquí no es el de comparar ediciones, no puedo dejar de señalar el hecho de que en la reescritura, parte de lo que es suprimido del texto son las referencias explícitas a diferentes géneros literarios. También cambia con el tiempo la forma que el propio autor tiene de considerar Operación masacre. Recordemos la entrevista a J. B. Brun, en 1958, en la que Walsh comentaba que ningún suplemento literario de los periódicos de la época le había dedicado un espacio; en cambio, en 1972, escribía: "La línea de Operación masacre era una excepción: no estaba concebida como literatura, ni fue recibida como tal, sino como periodismo, testimonio." (WALSH, 1996, p. 205).
} 
adentro como un hombre decidido, parco y extremadamente cauteloso. (p. 59) [la cursiva es mía]

En ninguno de los capítulos anteriores el "yo" del narrador hacía referencia al propio trabajo ni precedía la descripción de los personajes ${ }^{104}$. Se puede pensar que se trata de una forma de adhesión, de mayor aproximación al personaje; si antes el narrador era una mediador entre los personajes y el lector, que traía varios puntos de vista, ahora es solo su visión. Esto se reproduce en la recreación de los diálogos que mantienen ambos: el habla del narrador entra en estilo indirecto y la de Torres en directo:

—Yo no tengo por qué mentirle —me dijo-. Cualquier cosa perjudicial que usted me saque, diré que es falsa, que a usted ni lo conozco...

Sonrió sin animosidad. Le expliqué que comprendía las reglas del juego. (p. 60) [la cursiva es mía]

Al recrear las palabras de Torres en estilo directo no solo ganan un lugar destacado, también indican una forma de adhesión al personaje por parte del narrador. Además, se puede observar que hay aquí otro recurso de escritura puesto en práctica, en esa incansable búsqueda de una respuesta de cómo contar lo que sucedió.

\section{Pequeñas variaciones}

Los últimos tres capítulos dedicados a la construcción de la vida cotidiana de las víctimas reiteran estrategias anteriores, con pequeñas variaciones, reproduciendo de esa forma la estructura general de la primer parte de Operación masacre. Estamos nuevamente frente a protagonistas que aparentemente no sabían sobre el alzamiento; así el énfasis en la construcción de sus perfiles estará puesto nuevamente sobre los aspectos del día a día; y, una vez más, será la casualidad la que los lleve al "departamento del fondo". Como en los capítulos iniciales, habrá descripciones físicas, de carácter, de relaciones y pinceladas de historia de vida. Dos de las tres víctimas mueren en el basural, Mario Brión y Vicente Damián Rodríguez; la otra, es Juan Carlos Livraga, el "fusilado que vive". Los capítulos están enteramente dedicados a los personajes; ya no hay descripciones generales de los espacios, pues los tres son vecinos del mismo barrio, Florida.

\footnotetext{
${ }^{104} \mathrm{Ni}$ aun en el capítulo dedicado a "Giunta", donde el narrador plantea sus propias percepciones, pero no usa la primera persona.
} 
Aunque se retoman estrategias de construcción, cada personaje impone su propia singularidad. En el caso de Mario Brión, al igual que en el de Torres, las interferencias del narrador están en primera persona pero, esta vez, del plural. En este caso, la multiplicidad de perspectivas se da como consecuencia de un contrapunto de opiniones de vecinos y narrador:

Un muchacho serio y trabajador, dicen los vecinos. Una vida común, sin relieves brillantes, sin deslumbres de aventura, reconstruimos nosotros. (p. 63) [la cursiva es mía]

El mismo contrapunto se repite en el aspecto temporal:

No le hubiera costado trabajo lograrlo. En la empresa donde estaba se le había ofrecido ya una jefatura de sección. Ganaba bien: ninguna comodidad faltaba en su casa...

Mario Brión - dice la gente - es un muchacho alegre, amable con todos, un poco tímido. No fuma ni bebe. Sus únicas diversiones consisten en ir al cine con su esposa o en jugar al fútbol con sus amigos del barrio. (p. 64) [las cursivas son mías]

Aquí, a diferencia de los capítulos anteriores, el uso del tiempo presente ha sido dejado para los vecinos. Para poder interpretar esta variación de perspectiva habrá que avanzar bastante en la lectura. Así, más adelante sabremos que el nombre de Mario Brión no figuró en la lista oficial de fusilados y que fue la investigación del narrador la que llevó a confirmar su muerte:

El asesinato de Mario Brión fue denunciado por primera vez por mí en Revolución Nacional del 19 de febrero de 1957. Esa denuncia me puso en contacto con sus familiares, que aun se resistían a creer en lo irreparable. Las averiguaciones realizadas, infortunadamente confirmaron su muerte. (p. 176)

Además, a pesar de que el padre de Mario fue a retirar el cuerpo de su hijo a la morgue, donde "apenas se lo dejaron ver unos segundos" (p. 160), meses después don Manuel Brión todavía abrigaba la esperanza de que su hijo estuviese vivo pues había recibido una "misteriosa" llamada en la cual alguien quería hablarle de él. Así, parece que el "se resistían a creer" es el que dicta el contrapunto: como si el narrador ahora intentase "imponer" su saber sobre los hechos, para disminuir lo difuso, lo vago de la información. 
En el capítulo siguiente, "El fusilado que vive", al igual que en otros, el relato se divide en tres momentos: el de la presentación de Juan Carlos Livraga y su entorno; el de las dudas en relación a su conocimiento o no de la revolución; el del encuentro casual que lo lleva al departamento del fondo.

Juan Carlos Livraga, recordémoslo, "Será el único, entre los sobrevivientes o los familiares de las víctimas, que se atreva a presentarse para reclamar justicia." (p. 68). Recordemos también que es debido a la denuncia de Livraga que Walsh comienza la investigación que le cambiará la vida y que el embrión de Operación masacre será la nota "Yo también fui fusilado", publicada en Revolución Nacional, basada en la denuncia de este sobreviviente. ¿Por qué, entonces, el capítulo no ocupa un lugar destacado? ¿Por qué, por su contenido o su forma, no se diferencia de los otros? Tal vez porque Juan Carlos Livraga es un hombre común, un ciudadano simple, de la misma manera que las otras víctimas, con un día a día igual e igualmente quebrado como el de sus compañeros de fusilamiento; Juan Carlos Livraga forma parte de un colectivo alcanzado por la misma violencia y así lo entiende el narrador y así lo registra.

La ruptura se imprime en la forma del capítulo. Después de la descripción de Juan Carlos Livraga, sin una marca textual que lo anuncie o lo prepare, se pasa al cuestionamiento:

Ante el peligro se mostrará lúcido y sereno [...] Será el único, entre los sobrevivientes o los familiares de las víctimas, que se atreva a presentarse para reclamar justicia.

¿Sabe algo, esa tarde del 9 de junio, de la revolución que estallará después? Ha llegado a su casa antes de terminar su turno de trabajo, y esto podría parecer sospechoso. Pero el caso es que se le ha descompuesto el colectivo que maneja [...] y la empresa confirmará ese detalle. (p. 68)

Observemos que además del corte en la secuencia, aquí también el narrador se apoya en confirmaciones "externas" para construir la demostración de la inocencia de este sobreviviente: tres párrafos, insistentemente, comenzarán con variaciones sobre la misma pregunta (“¿sabe algo...?”); tres respuestas confirmarán su inocencia. 
La última parte del capítulo describe los movimientos de Livraga la noche del 9 de junio, desde que sale de su casa hasta que se encuentra con Vicente Rodríguez, otro de los fusilados. El paso de una parte a otra vuelve a producirse como un corte. La falta de conectores que establezcan una relación lógica de causalidad, entre las diferentes partes, parece ser la representación de la falta de causalidad inscripta en los propios hechos.

El capítulo termina cuando Livraga y Vicente Rodríguez se encuentran: "La casualidad decide por él. La casualidad que le sale al paso en la persona de su amigo Vicente Rodríguez." (p. 69). Así, después del encuentro, la acción se detiene en la descripción de Vicente Rodríguez. Y como la casualidad vale para ambos, en "Me voy a trabajar" también se pueden distinguir tres momentos (aunque eso en principio no sea transparente por la diferencia de tonos y recursos): el de la descripción, el de las dudas del narrador, y el del encuentro con Livraga y la llegada al departamento del fondo.

Aquí, se retoman algunas estrategias, sobre todo las del primer capítulo, "Carranza": sin duda el narrador siente una simpatía especial por estas personas que luchan y no se conforman. Ambos tienen en común eso: son perseguidos, excluidos y, finalmente, derrotados por el sistema, pero sus gestos serán los de la resistencia: uno a través de la militancia; el otro, a través de la lectura. Aquí, a diferencia del capítulo dedicado a Carranza, la enumeración y la repetición producirán un efecto de urgencia, de desesperación; la misma desesperación de Vicente Rodríguez frente a la muerte que no termina de llegarle:

Es una torre de hombre este Vicente Damián Rodríguez, que tiene 35 años, que carga bolsas en el puerto, que pesado y todo como es juega al fútbol, que guarda algo de infantil en su humanidad gritona y descontenta, que aspira a más de lo que puede, que tiene mala suerte, que terminará mordiendo el pasto de un potrero y pidiendo desesperado que lo maten, que terminen de matarlo, sorbiendo a grandes tragos la muerte que no acaba de inundarlo por los ridículos agujeros que le hacen las balas de los máuseres. (p. 71)

Un único párrafo, una oración principal y diez subordinadas que buscan construir la singularidad del personaje; pero en la restricción que implica esa forma está representada la propia restricción impresa en la muerte. Restricción y muerte parecen evocadas, 
remarcadas y machadas en la reiteración. La reiteración se produce también en el campo de los contenidos:

Hubiera querido ser algo en la vida, Vicente Rodríguez. Está lleno de grandes ideas, de grandes ademanes, de grandes palabras. Pero la vida es feroz con gente como él. Solamente ganarla será una permanente cuesta arriba. Y perderla, un interminable trámite. (p. 71)

Este párrafo retoma, amplía y explica el primero. La inversión sintáctica que destaca el deseo y el fracaso vuelve sobre la imposibilidad que trajo la muerte: "hubiera querido" significa que ya no podrá seguir luchando por sus deseos.

Al igual que en el capítulo anterior, el paso de la descripción al encuentro con Livraga se produce sin solución de continuidad:

Cabe suponer que jamás pensó que lo iban a matar, ni aun a último momento, cuando eso era evidente.

Conversan un momento los dos amigos. Livraga le ha prestado días antes una valija destinada a llevar los equipos del club de fútbol en el que ambos juegan. (p. 73)

El relato se había detenido en la escena del encuentro y ahora vuelve a ese momento con el "conversan", sin ninguna otra marca textual que lo anuncie, poniendo así de manifiesto en la propia estructura del capítulo el corte impreso en la vida de estas personas por la arbitrariedad del fusilamiento.

El capítulo final de la primera parte, "Las incógnitas", recapitula los movimientos en el departamento del fondo durante la noche del 9 de junio, y le da comienzo a la acción ${ }^{105}$. Pero además, marca el momento de la ruptura de una situación familiar, habitual y conocida, tanto para los que no sabían nada sobre la revolución, como para aquellos que sabían o eran revolucionarios; éstos en ningún momento pensaron que el desarrollo de los hechos tomaría el cariz que tomó.

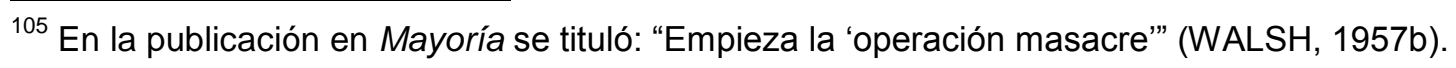


La forma fragmentada del capítulo reproduce y anuncia la desintegración que vendrá con el fusilamiento. El foco narrativo pasa de un espacio a otro, intentando registrar el mismo momento en diferentes lugares: el departamento del fondo y el del frente, de don Horacio; el Puente Saavedra, donde la policía está requisando un ómnibus; la Comisaría $2^{a}$ de Florida, en la cual "han terminado de concentrarse veinte hombres, para un misterioso procedimiento." (p. 77); las transmisiones radiales: "Radio del Estado, la voz oficial de la Nación" que transmitió un concierto de Bach y comienza otro de Ravel; Radio Splendid desde el Luna Park, donde están teniendo lugar "las primeras incidencias del match." ( $p$. 77).

Así llegamos al final de la primera parte de Operación masacre. El narrador fue construyendo "disciplinadamente" un capítulo para cada persona y destacando la tranquilidad —o el sobresalto — de un día a día marcado por lo que tiene de rutinario; en ese contexto, la casualidad de los encuentros que llevó a las víctimas al lugar donde fueron detenidas aparece como dato clave de la construcción. Antes de la masacre, las personas no formaban un colectivo; el fusilamiento les da esa condición y la ficción la reconstruye por acumulación: sistemáticamente un capítulo para cada uno de los personajes reunidos en una única parte.

En el caso de los que sabían o estaban comprometidos con la Revolución, el armado del perfil del personaje privilegia los motivos que llevaron a la opción política, pero no hace de esta el eje de la construcción: prácticamente no hay información sobre el trabajo revolucionario y, cuando la hay, aparece diluida; es decir, se disuelve en la ficción el acto de atentar contra un gobierno de facto. La escritura de esta primera parte resiste a construir el grupo de involucrados como sospechosos; todos son víctimas de la misma violencia. La conciencia de la desproporción entre el acto (participar en la Revolución) y la violencia del castigo dicta la forma de "Las personas".

\subsection{CÓMO NARRAR LA MATANZA: "Los hechos”}

La segunda parte de Operación masacre relata desde el momento en que las personas son arrancadas de sus vidas cotidianas — reunidas para escuchar una pelea de box- 
hasta que, tiempo después, dos de los sobrevivientes son puestos en libertad; en orden cronológico se narra: la detención, el fusilamiento, la búsqueda de las familias de muertos y sobrevivientes, la liberación.

Después de la invasión del "departamento del fondo" y de la detención de las personas, el foco del relato se centra alternativamente en el grupo de prisioneros, en la comisaría donde están detenidos - Unidad Regional San Martín_, en los lugares de combate, en la casa de gobierno — de donde salen los comunicados oficiales-. El tiempo va siendo marcado explícitamente: varios capítulos empiezan con indicación de horas y minutos. También, en toda esta parte predominan las marcaciones espaciales. A partir de "La matanza", el foco volverá, hasta el final de "Los hechos", insistentemente sobre cada una de las víctimas.

Así como en la primera parte de Operación masacre la acumulación y yuxtaposición de cuadros de la vida cotidiana iban creando el perfil de los personajes y el narrador era un mediador entre estos y el lector, en la segunda, concentrada en el progreso de la acción, los mismos recursos servirán para construir el relato de los hechos acumulando actos, y la voz del narrador ensayará diferentes lugares desde donde contarlos.

\section{La detención}

El capítulo que abre la segunda parte de Operación masacre, “¿Dónde está Tanco?”, se divide en dos partes, separadas gráficamente por asteriscos. La primera abarca desde el momento de la irrupción policial hasta que todos los detenidos se encuentran fuera del local de la invasión, en un colectivo que los trasladará a la comisaría de Florida. La segunda parte, más corta, es el relato de una escena que transcurre en el interior de la casa de Don Horacio, presenciada por su esposa y su hija. En este capítulo, el lugar de enunciación del narrador continuará siendo el mismo de la primera parte de Operación masacre; con su palabra se mezclarán léxico y sintaxis de los protagonistas.

Nos deparamos al principio del relato con la perplejidad del dueño de casa ante la llegada de la policía; es todo rápido y apabullante: correr, abrir la puerta, un cerrojo que salta, armas y voces que gritan; y Don Horacio “impelido, rodeado, desbordado por el tropel de 
policías y particulares" (p. 81). La misma violencia se repetirá enseguida con Miguel Ángel Giunta. Toda la escena, "rápida, electrizante", culmina en el momento en que Don Horacio y Giunta son introducidos en un coche de la comisaría de Florida. La forma del relato retoma las frases nominales, las oraciones coordinadas, las enumeraciones y yuxtaposiciones:

Tan desconcertado está don Horacio, que no atina a dejar la bolsa. Corre, hace girar la llave en la cerradura, y antes que termine de sacar la cadena, la puerta es impulsada con violencia desde afuera, salta el cerrojo y él se ve impelido, rodeado, desbordado por el tropel de policías y particulares provistos de armas largas y cortas, que en pocos segundos inundan todas las dependencia y cuyas voces no tardarán en oírse en el patio y en el pasillo, que conduce al fondo. Todo sucede con velocidad de relámpago. (p. 81)

El foco entonces se dirige al pasillo que une la casa de Don Horacio y el departamento del fondo. De allí, del pasillo, "ha escapado un hombre - Torres_, y otro — Lizaso_ parece haberlo intentado sin éxito." (p. 83); aquí el relato de la acción se detiene en las diferentes versiones sobre cómo fue capturado Carlos Lizaso. Y, finalmente, llegamos al departamento del fondo al cual "La policía entra sin hallar oposición. Nadie mueve un dedo. Nadie protesta ni se resiste." (p. 83); se repiten los gritos y los golpes y las detenciones.

Al igual que en la primera parte, se observa aquí que la voz del narrador también se contagia con el decir de los diferentes protagonistas: tanto de las formas coloquiales de las víctimas - “velocidad de relámpago" se lee en el párrafo citado anteriormente_, como de la dureza de los victimarios:

El jefe lo hace a un lado de un empellón y se encara con el otro, con Giunta. (p. 82)

Del patio de la finca, entretanto, ha escapado un hombre - Torres_, y otro _Lizaso_ parece haberlo intentado sin éxito." (p. 83) [la cursiva es mía]

En ambos casos el uso de "otro" indica un distanciamiento, como si el narrador no conociese a las personas; en el primer ejemplo, además, es despectivo; parece que estamos oyendo al jefe de la operación. Pero, también observamos la tensión que se establece entre "otro" — que no determina_ o "un hombre" y la inmediata aclaración del 
apellido para diferenciar a las personas. La misma tensión se establece en la construcción del perfil del jefe de policía. Al principio, el invasor es un cuerpo, un arma, una voz que grita y ordena, un uniforme:

Alto, corpulento, moreno, de bigotes, impresionante de autoridad, es el que manda el grupo. En la mano derecha empuña una pistola 45. Habla a gritos, con voz ronca y pastosa que por momentos parece de borracho. Viste pantalones claros y chaquetilla corta, color verde oliva: es el uniforme del Ejército Argentino. (p. 81)

Y al final de la primera parte del capítulo la voz del narrador define a "ese" hombre con cargo, nombre y apellido:

"Ese", el hombre que dirigía el procedimiento, el militar vestido de uniforme, el imparcial dispensador de culatazos y trompadas, a quien todos tratan respetuosamente de "señor", [...] ese hombre era el jefe de Policía de la Provincia de Buenos Aires, teniente coronel (R) Desiderio A. Fernández Suárez. (p. 85)

En ese momento, la narración podría continuar adelante, hacia el relato del fusilamiento en sí: a los protagonistas ya los conocemos, al jefe de la operación también; ya sabemos quién huyó y quién fue detenido; como acompañando una cámara, hemos ido de la casa de Don Horacio, al pasillo, al departamento del fondo y a la calle. Pero la cámara vuelve a la casa del Don Horacio.

Esta parte de la historia está separada de la anterior por un espacio mayor y marcado con asteriscos. Muestra al jefe de la operación hablando por teléfono, probablemente con una mujer, y colaborando en el registro de la casa. La necesidad de apuntar los pormenores parece indicar una búsqueda de cercar, de aprehender una explicación, probando diferentes puntos de vista: aquí el narrador reproduce lo que probablemente le contaron la esposa e hija de Don Horacio, al mostrar a Fernández Suárez hablando con un tono de voz diferente y con una mujer:

Están llamadas [madre e hija], sin embargo, a presenciar un raro interludio. Es el señor jefe de Policía que vuelve, que toma el teléfono y que habla con voz cambiada. Son apenas unos fragmentos de conversación y un nombre de mujer los que alcanzan a escuchar: 
-...Con todo éxito... Magnífico... Parece que en el Sur también se levantaron...

Decíle a Cacho que se cuide... Sí, con todo éxito... (pp. 85-86)

La locución "sin embargo", la idea de "interludio", la voz "cambiada" y el "Decile a Cacho que se cuide..." por un momento podría inducir a pensar en una cara menos brutal del jefe de policía. Sin embargo, lo que leemos a continuación ("Con todo éxito...") recuerda la forma castrense de reportarse a un superior. Además, estos párrafos están enmarcados por otros dos que no dejan duda de cómo el narrador interpreta esta escena. En el primero, se describe la situación que viven la señora Pilar y Nélida como una "pesadilla" interminable; a continuación se enumera el porqué de esa sensación:

La casa sigue invadida de hombres que revisan muebles y cajones, que interrogan, que hablan a los gritos. De afuera llegan todavía las órdenes secas como balazos. (p. 85)

Aquí, el dato nuevo es que los hombres revisan muebles y cajones; que interroguen y griten intensifica la sensación de violencia. También la forma de la escritura es conocida: en este caso, la enumeración con yuxtaposición. El párrafo siguiente al de la conversación telefónica de Fernández Suárez habla por sí solo. Allí leemos:

Nélida pretende alejarse del dormitorio donde el señor jefe de Policía busca entre prendas de ropa interior fabulosos planes revolucionarios, o quizás al mismo Tanco. (p. 86)

No se puede negar el humor, aunque incómodo, y el sarcasmo del pasaje en la descripción e hipótesis aquí hechas.

Al finalizar la primera parte de este capítulo, ya conocemos el nombre y el rango del jefe de policía; aun así, el narrador insiste en no llamarlo por su nombre y acompañar su cargo con el epíteto "señor". Por un lado puede ser otra ironía, como negando, frente al lector, la idea de "respetable" que invoca la palabra "señor". Por otro, cabe recordar que el propio jefe de Policía al verse denunciado por el abogado Doglia, dice "Único caso en mi Jefatura [...] en que un señor de la calle...” (p. 181). Así puede tratarse de una forma que el narrador tiene de recordarle al policía que él también es un señor cualquiera. Pero, además, y sobre todo, "jefe de policía" no permite olvidar que es una institución del Estado la que lleva adelante los procedimientos. 
La acumulación de fragmentos — en forma y contenido - lleva a pensar, por un lado, en la búsqueda de la precisión que requiere el asunto ${ }^{106}$. Por otro, ese registro de menudencias también induce a pensar en la imposibilidad de presentar los hechos en forma cerrada y concisa; en fin, en la dificultad para encontrar la manera y el lugar adecuados desde donde hacer el relato. Así el narrador irá construyendo el espacio de enunciación de "Los hechos".

Este capítulo cierra con un comentario del narrador sobre la operación, con indicación de la hora precisa y la programación de ese momento de Radio del Estado, otra voz, "la voz oficial de la Nación":

La primera etapa de la "Operación Masacre" ha sido rápida. Son apenas 23.30. En ese preciso momento, Radio del Estado, la voz oficial de la Nación, cesa de transmitir la música de Ravel y comienza a pasar el disco 6489/94 de lgor Stravinski. (p. 86)

\section{La espera}

En los capítulos siguientes, hasta "La matanza" acompañamos tres historias: la del alzamiento, la de la reacción oficial al mismo, y la de las víctimas y sus victimarios. La primera aparece en un capítulo separado, "La revolución de Valle". La segunda se entremezcla con la tercera en títulos de capítulos y comunicados oficiales.

Así, después de la detención de los protagonistas hay una nueva interrupción en la narración. Esta vez se trata de situar los hechos en el marco histórico; para eso, el

\footnotetext{
${ }^{106}$ En Walsh esta precisión significa tener en cuenta la posibilidad de múltiples significados de las palabras. En "Claroscuro del subibaja", publicado en 1964, después de citar algunos ejemplos de idiomas antiguos en los que existían palabras únicas que afirmaban cosas opuestas -Yüanchin, lejos-cerca ... Wang-chi, recuerdo y olvido del recuerdo_, leemos: "Más tarde, intervinieron los letrados. Observaron que esa manera de hablar y de pensar, aunque acorde con la íntima esencia de las cosas, conducía al estancamiento y quizá a la aniquilación de la vida, que para conseguir sus fines necesita de afirmaciones y negaciones cerradas, o sea la mitad de cualquier verdad" [la cursiva es mía] (WALSH, 1996, p. 46). Aun sobre la cuestión de la precisión, en "Calle de la Amargura número 303", al comentar las elecciones hechas por él mismo para una traducción, el autor afirma: "Hartos, ahítos, atragantados' -la revista usa una sola palabra, gorged, pero a mí, que soy mal traductor, me hacen falta tres para conferirle su sentido íntegro-..." Walsh, Rodolfo. Ese hombre y otros papeles personales. Argentina, Seix Barral, 1996, (p. 15).
} 
narrador, ocupará la posición de periodista notero ${ }^{107}$. "La revolución de Valle"108 empieza con el anuncio y la noticia del levantamiento:

Lejos de allí, el verdadero alzamiento arde ya furiosamente.

En junio de 1956, el peronismo derrocado nueve meses antes realizó su primera tentativa seria de retomar el poder mediante un estallido de base militar con algún apoyo civil activo. (p. 87)

A continuación, hay un relato del desarrollo de las acciones en cada uno de los lugares en que llegó a producirse el alzamiento: Campo de Mayo, Escuela de Mecánica del Ejército, Avellaneda, La Plata, y un análisis de la proclama firmada por los generales Valle y Tanco, jefes del levantamiento. Es a partir de ese análisis que se le da continuidad a la caracterización, ahora en contrapunto, de los policías que llevaron a cabo el fusilamiento. Después de describir la proclama de los generales rebeldes y antes de llegar a una síntesis sobre los "aspectos que en aquellos tiempos iniciales de la resistencia caracterizaron al peronismo" (p. 88), el narrador comenta los "aciertos" del bando:

La proclama de Valle estaba singularmente desprovista de hipocresía. No contenía la habitual invocación a los valores occidentales y cristianos ni los denuestos contra el comunismo...

\section{$[\ldots]$}

Por supuesto Valle actuó y entregó su vida, y eso es mucho más que cualquier palabra. La comprensión de su actitud es hoy más fácil ${ }^{109} \ldots$ (p. 88)

Y un poco más adelante, al comentar el alzamiento en los diferentes lugares del país, en particular en el Departamento de Policía de La Plata, se lee:

\footnotetext{
${ }^{107}$ Aquí uso la definición que da Ana Atorresi en Los géneros periodísticos: "El trabajo de investigación cerrado o nota es la especie periodística que asume la función de formar además de informar, ya que tiende a mostrar determinados aspectos de un acontecer que no siempre son accesibles a los lectores. El periodista notero recopila datos históricos, culturales, científicos, sociales, etc. y es frecuente que incluya en la nota la opinión de especialistas en el tema." (ATORRESI, 1996, p. 29)

${ }^{108}$ El nombre oficial dado por los revolucionarios al levantamiento obrero-militar de junio fue "Movimiento de Recuperación Nacional" (BURGOS, 1994, p. 123). Este mismo autor dice que la Revolución Libertadora, después de los fusilamientos, se conoció popularmente como "la revolución fusiladora" (p. 122).

${ }_{109} \mathrm{El}$ análisis que leemos en este capítulo consta solo a partir de la tercera edición de Operación masacre (1969), cuando Walsh ya había sido jefe de redacción del periódico CGT de los Argentinos (Confederación general del trabajo de los Argentinos, CGTA), grupo obrero rebelde a la CGT oficial, que actuó entre 1968 y 1969 y era dirigido por el líder católico revolucionario Raimundo Ongaro. Tenía una publicación "editada entre bastidores", CGTA, dirigida por Rodolfo Walsh.
} 
$\mathrm{Ni}$ el jefe ni el subjefe se encuentran en él. El primero está revisando los muebles de don Horacio di Chiano, en Florida. El segundo, dirigiendo la represión en Avellaneda y Lanús. (p. 90)

La ironía y las oraciones cortas y asertivas se contraponen al comentario emitido antes sobre el general Valle: mientras uno actúa y entrega la vida, el otro busca al general Tanco entre la ropa interior de la hija de Don Horacio.

La voz narrativa, en este capítulo, al asumir el lugar de periodista está más próxima a la del propio autor. Y, más cercana todavía por la inclusión de una nota al pie de página en la que se da una referencia bibliográfica de dónde leer sobre los hechos: "Puede encontrarse un relato detallado de las operaciones y de la represión subsiguiente en el libro de Salvador Ferla Mártires y verdugos, publicado en 1964."110 (pp. 174-175). Aquí hay un doble movimiento, por un lado el narrador incluye el punto de vista, el del autorperiodista; por otro, con esa inclusión está amparándose en la autoridad tanto del autor como en la del historiador.

La narración de los hechos es retomada en "'A ver si todavía te fusilan...”. Como en toda la segunda parte, aquí se va construyendo el relato como una red, con fragmentos de tiempo y espacio; el foco de la narración se detiene y explora varias situaciones: vuelve al colectivo en el que están los prisioneros y describe su recorrido hasta llegar a la Unidad Regional de San Martín ${ }^{111}$; y vuelve, también, al "departamento del fondo" en el cual todavía quedan policías, que detienen a otras dos víctimas, Julio Troxler y Reinaldo Benavídez. Ambos son llevados a la "Segunda de Florida", donde se encuentra el comisario Pena, que conoce a Troxler.

Se puede tener una dimensión de lo inesperado de los sucesos, del fusilamiento, en la reacción tanto de Troxler y Benavídez como de los policías. Ante la detención, la reacción de unos y otros es tranquila: "Es cierto que están desarmados, pero si se lo proponen pueden tal vez reducirlos [a los policías] y escapar." (p. 95); "La actitud de los vigilantes de la custodia es correcta o despreocupada." (p. 93).

\footnotetext{
${ }^{110}$ Hasta la segunda edición inclusive, en lugar de la referencia citada, se leía la transcripción de trechos de cartas de informantes (WALSH, 1957, p. 55).

${ }^{111}$ Partido del Gran Buenos Aires.
} 
No ocurre lo mismo entre los detenidos que esperan en el colectivo. El desconcierto y lo absurdo que se presiente en la situación quedan registrados en sus charlas:

— ¿Por qué nos llevarán? -interroga uno.

- Y qué sé yo... — contesta otro-. Será por jugar a las cartas.

-Me huele mal. El grandote dijo algo de una revolución.

Los más desconcertados son don Horacio y Giunta. Porque ellos ni siquiera jugaban a las cartas. (p. 93) [la cursiva es mía]

Que el narrador se apropie del chiste (detenidos por jugar a las cartas) acentúa la ironía contenida en la hipótesis del detenido. En ese sentido, también el título del capítulo, "A ver si todavía te fusilan", comentario chistoso que le hace el comisario Pena a Troxler, al convertirse en realidad contribuye a lo irónico del relato.

A medida que los hechos se van aproximando al momento del fusilamiento, aumenta la dificultad de nombrarlo y relatarlo:

A Benavídez va a sucederle algo increíble, algo que aun ubicado en esa noche de singulares aventuras y experiencias parece arrancado de una exuberante novela. Pero ya volveremos sobre ello. (p. 95) [la cursiva es mía]

El trecho transcripto es el final de un párrafo, el único, dedicado a la descripción de Benavídez. Después, mucho más adelante, sabremos que lo "increíble" es que Benavídez apareció en la lista oficial de muertos cuando, en realidad, fue uno de los que consiguió huir del basural. Las intervenciones del narrador que anticipan y califican lo que pasará tienen algo de exagerado o inadecuado —el fusilamiento es algo más que un "suceso" "raro"- La elección de los calificativos crea, nuevamente, extrañamiento, nos obliga a estar alertas; pero no solo preparados para lo que vendrá sino también frente a esas elecciones lingüísticas. Lo mismo puede decirse de "Por singular coincidencia —que después va a repetirse_-, u "Horas más tarde, en circunstancias más difíciles, casi imposibles..." (p. 95). Más que pistas sobre la acción (sobre lo que vendrá), más que crear misterio, parecería que con estas intervenciones el narrador nos da indicios de cómo leer el relato de los hechos; deja al descubierto la técnica y la intencionalidad; incomoda por lo 
obvio; su discurso se construye con fisuras, con grietas. El narrador no se deja ver con voz serena.

Este capítulo no avanza mucho en la acción: en relación a los detenidos, transcurre menos de una hora y la escena está parada en el interior del colectivo. Pero aquí se le da continuidad a la construcción de la demostración, comenzada en el capítulo anterior, sobre la ilegalidad de los fusilamientos. Recordemos que lo fundamental es que los prisioneros fueron detenidos antes de la promulgación de la ley marcial. De ahí que el tiempo vaya siendo marcado a partir de las transmisiones oficiales de Radio del Estado, ya que es a través de este medio que la población se enteraba de los hechos oficiales. A las 0:11, Radio Nacional reanuda la transmisión y "por espacio de veintiún minutos propala $^{112}$ una selección de música ligera" (p. 94) y, a las 0:32, transmite "un comunicado de la Secretaría de Prensa de la Nación, promulgando dos decretos." (p. 96).

Dice así el dramático anuncio:

"Considerando que la situación provocada por los elementos perturbadores del orden público obliga al gobierno provisional a adoptar con serena energía las medidas adecuadas para asegurar la tranquilidad pública en todo el territorio de la Nación, así como el normal cumplimiento de las finalidades de la Revolución Libertadora, por ello, el presidente provisional de la Nación Argentina, en ejercicio del Poder Legislativo, decreta con fuerza de ley:

$[\ldots]$

El segundo decreto, considerando que la Ley Marcial "constituye una medida cuya aplicación debe ser reglamentada para conocimiento de la población" dispone las normas y circunstancias en que se llevará a la práctica. (pp. 96-97) [las cursivas son mías]

Notemos que para estas nuevas "voces" que van entrando en el relato (Radio Nacional, los comunicados de la presidencia), el narrador hace un único comentario: "dramático anuncio"; después, la proclama habla por sí sola: "serena energía", "medidas adecuadas", "tranquilidad pública", etc. Un único comentario del narrador y la transcripción del anuncio acentúan la ironía con la que se va construyendo la representación de las instituciones oficiales.

\footnotetext{
112 Parecería que la elección de este verbo va en la línea ya apuntada de crear extrañamiento; está usado en el sentido de "propagar", sin embargo, su significado es el de "divulgar algo oculto".
} 
Una vez en la comisaría, el foco del narrador, luego de describir el ambiente, se detendrá en los diferentes grupos de prisioneros: en su asombro y en sus conjeturas. Hay diálogos en estilo directo (Livraga - Rodríguez); descripciones de estados de ánimo (Giunta - Don Horacio, Gavino); afirmaciones e hipótesis del narrador sobre actos y pensamientos de las víctimas que murieron en el basural (Brión, Lizaso, Garibotti, Carranza).

Mario Brión piensa en su esposa que ha de estar esperándolo, sin saber nada. Él nunca ha llegado tan tarde.

¿Se acuerda Carlitos Lizaso de aquel mensaje que dejó a su novia? "Si todo sale bien esta noche..."

Garibotti se lamenta de haberle hecho caso a su amigo Carranza, que está abatido y silencioso a su lado. Vaya a saber ahora cuándo los van a soltar, tal vez a la madrugada o al medio día siguiente... Carranza, a su vez, recuerda las palabras de Berta: "Entregáte, entregáte...". Bueno, ya está entregado. Los demás puede que salgan, pero él... Apenas pidan sus antecedentes, está sonado. Tal vez piensa en aquel día en que se les disparó a los milicos tucumanos. (p. 100) [la cursiva es mía]

De algunas víctimas solo sobraron "murmullos"; ante la imposibilidad de la información, y en la búsqueda de reconstruir los hechos, el narrador asume el estilo indirecto libre, se coloca en el lugar de los personajes, relata sus angustias. Pero tampoco puede llevar esta forma hasta el fin; de ahí que entre afirmaciones ("piensa", "se lamenta", "recuerda") se filtren dudas (“¿Se acuerda...?”) y conjeturas (“Tal vez piensa...”).

Tal vez, porque Walsh trabajaba con "la noción de que hay excepciones en el imperio del mal"113 es que, en "Los hechos", también indaga entre los victimarios (por esa noción y porque, como ya señalé, considera que hay que "ver las dos caras de la moneda"); se aproxima de a poco, pero lo hace insistentemente. En este capítulo, el párrafo que lo abre, registra la actitud "correcta" de los vigilantes que custodiaban a los prisioneros y, al final, la simpatía del comisario Pena por Troxler, que también fue policía durante el

\footnotetext{
${ }^{113}$ Horacio González, en "Bastardillas y metamorfosis", al comentar "Aramburu y el juicio histórico", último capítulo de Operación masacre", afirma que la novela "está escrita con una doble ambición moral. Primero con la noción de que hay excepciones en el imperio del mal, excepciones irreflexivas a cargo de hombres comunes y frágiles." En segundo lugar, dice que "también está escrita con la idea de que un mundo efectivo y palpable, en su lógica combatiente, es siempre más que las vacilaciones de una conciencia que reclama un juicio particular...”. (GONZÁLEZ, 1998, pp. 24-25)
} 
peronismo y que, por no compartir los métodos, dejó la institución. En "Pónganse contentos'” la aproximación es más decidida; en el párrafo que abre el capítulo se lee:

0.45. En la Unidad Regional han bajado a los prisioneros del colectivo. Los llevan por una larga galería y los introducen en una oficina situada a la izquierda, donde hay varios bancos de plazas, de color verde, en los que van tomando asiento. El edificio parece en refacciones. Las paredes de esa habitación están recién pintadas, y todavía quedan por ahí algunos elementos de pintura. (p. 99) [la cursiva es mía]

Lo primero que se podría pensar al leer este pasaje es que se trata del registro de detalles para dar una idea "física" de la comisaría; además remite a la imposibilidad de sintetizar, dictada por la búsqueda de comprensión, como si con la acumulación de información se pudiese tener una idea más cabal del todo. Pero aun hay otra alternativa, la descripción del espacio caracteriza a los que allí trabajan: alguien se preocupa por refaccionarlo, aunque queden "por ahí" las muestras de ese trabajo.

Más explícita es la secuencia final de este capítulo. Después de describir el combate en diferentes puntos de La Plata, cierra con cuatro párrafos dedicados a Juan Carlos Longoni, inspector de policía y ayudante de Doglia; uno de ellos dice:

Esa noche Longoni está durmiendo en su casa cuando oye los primeros tiros. Se levanta y sale vistiéndose a la calle. Para un taxi y se hace llevar a la zona de lucha. En lo más denso del tiroteo, el taxista se desmaya del susto. Longoni lo deja en la Asistencia, sigue solo, y logra meterse en el Comando. Pide un arma y un puesto de combate. Le entregan una Halcón y le dan a elegir el puesto que quiera. Toda la noche pelea. (p. 102)

A continuación constan unas líneas que permiten entender el porqué de la inclusión de estos detalles en la historia: "Ese es el hombre a quien siete meses más tarde el jefe de Policía de la Provincia [Fernández Suárez] dejará cesante [...] por secundar a Doglia en sus denuncias sobre este caso." (p. 102). Pero, además, este pasaje parece estar dirigido a los interlocutores que podrían leer Operación masacre como un ataque al gobierno de la "Revolución Libertadora". Digo esto porque se mantiene el mismo pasaje desde la primera edición, cuando el narrador todavía cree que ese "es el servicio que prestan al actual 
gobierno algunos ${ }^{114}$ funcionarios." (p. 259). La inclusión de detalles como este habla de la necesidad de persuadir al lector de que se tienen en cuenta las dos caras de la moneda, 0 por lo menos que se intenta.

Los capítulos siguientes, "Calma y confianza""115 y "Que nadie se equivoque", transcurren en la comisaría, con flashes en algunos lugares de combate (La Plata, Río Santiago). Aquí, además de registrar escenas entre los detenidos, se construye el perfil de Rodolfo Rodríguez Moreno, el encargado material del fusilamiento, jefe de la Unidad Regional San Martín (p. 103); el mismo cuyas palabras constan en el epígrafe a Operación masacre a partir de la tercera edición (WALSH, 1969). Al principio, en "Calma y confianza", Rodríguez Moreno es un nombre y un cargo; alguien en cuyo despacho está encendida la radio. Luego, leeremos la ficha "profesional" de Rodríguez Moreno y del segundo jefe de la Unidad Regional, el comisario Cuello.

"Que nadie se equivoque" comienza, como los capítulos anteriores, con una indicación temporal, pero le sigue de inmediato el registro de las preocupaciones del jefe de la Unidad Regional:

2.45. Rodríguez Moreno tiene un mal pálpito. ¿Por qué a él, justamente a él, tenían que caerle estos pobres diablos? $Y$ sin embargo, hay como una misteriosa justificación, una fidelidad del destino en la misión que le va a tocar. (p. 107)

La sensación del comisario no es buena, algo lo preocupa: "tiene un mal pálpito". En la pregunta, en estilo indirecto libre, que recuerda la forma de lamento o de queja ante algo que se siente como injusto “¿por qué a mí, justo, a mí...?”, el adverbio y la repetición del pronombre resaltan la sensación de pesadumbre; pero la expresión coloquial "pobres

\footnotetext{
${ }^{114}$ En el "algunos" se manifiesta la visión de Walsh: es la época en que todavía creía en la justicia y en el modelo de Estado que representaba la "Revolución Libertadora". En una entrevista (antes mencionada) de 1958, que le hace Juan Bautista Brun a Rodolfo Walsh, este dice: "Tengo el convencimiento de que gran número de oficiales de carrera sienten el fracaso de ésta y de otras investigaciones como una afrenta, y lo atribuyen al hecho de que en los últimos años la institución ha estado en manos de personas ajenas a ella y atadas por intereses políticos." (BRUN, 1994, p. 149-150)

${ }^{115}$ Hasta la tercera edición el título era "Revoluzione", palabra que repetía uno de los prisioneros que será liberado a último momento. Como comenté anteriormente, estos cambios hay que pensarlos a la luz de la experiencia política que Walsh ha adquirido para 1969.
} 
diablos", con su sentido de "hombre bonachón y de poca valía" ${ }^{116}$, atenúa el peso de la queja. Las comparaciones y afirmaciones subsiguientes - "misteriosa justificación" y "fidelidad del destino"-, en principio, pueden ser irónicas y aun desde el punto de vista del propio Rodríguez Moreno; pero también pueden rescatar una eventual incomprensión del lector. Tal vez, la dilucidación la tengamos en el comienzo del próximo párrafo:

Hombre imponente, duro, de accidentada y tempestuosa carrera es Rodríguez Moreno. La tragedia lo sigue como un perro devoto... (p. 107)

"Imponente" —que infunde respeto, miedo u asombro—y "duro" —que resiste y soporta bien la fatiga; áspero, falto de suavidad, excesivamente severo-, después del primer párrafo, resultan adjetivos ambiguos: puede ser que infunda respeto por seriedad y competencia o simplemente que infunda miedo. La misma ambigüedad se desprende de "accidentada" - algo que no forma parte de la esencia; suceso eventual que altera el orden regular de las cosas - y "tempestuosa" — que causa o constituye tempestad; esta idea nos puede conducir a la de "tormentosa": o sea, llena de tensiones y conflictos-. También, en la palabra "tragedia" está implícito algo de involuntario ${ }^{117}$, reforzado por la comparación que trae lo irracional del "perro devoto". O sea, hasta aquí, Rodríguez Moreno parecería víctima del destino; pero no se puede perder de vista la ambigüedad implícita en "accidentada" y "tempestuosa".

A continuación, en el mismo párrafo y en el siguiente, se relatan los hechos concretos que justifican las observaciones del narrador: la muerte de un linyera, de un carterista chileno, de un vigilante; además del fusilamiento de José León Suárez. En el mismo párrafo, a continuación de la cita anterior, leemos:

Ya antes de 1943, estando al frente de una comisaría de Mar del Plata, aparece complicado, según versiones, en un hecho escalofriante. Un linyera es golpeado brutalmente en un calabozo y arrojado luego a una playa, completamente desnudo en una noche de crudo invierno. Muere de frío. Parece que a Rodríguez Moreno lo procesan y hasta lo encarcelan en Dolores. Pero después sale en libertad. Porque era inocente, dicen sus defensores. Por

\footnotetext{
${ }^{116}$ Todas las definiciones fueron consultadas en el Diccionario de la Real Academia Española (DRAE) o en el Clave, diccionario de uso del español actual.

117 Pienso en el héroe trágico.
} 
influencias políticas, sostienen sus detractores. El episodio queda oscuro y olvidado. (p. 107)

Las acotaciones — “según parece", "parece", "dicen”, "sostienen”_, además de confirmar, desde otras perspectivas, lo controvertido del personaje y mostrar la búsqueda de fidelidad del narrador-periodista al señalar que son versiones y que, tal vez, no las investigó personalmente, también destacan sus dudas en cuanto a este personaje y al hecho de que cumpla órdenes. Ahora, observemos la forma de calificar los hechos: "escalofriante", "brutalmente", etc., que trae a la memoria el lenguaje de la crónica policial y puede producir un cierto distanciamiento, por lo estereotipado; distanciamiento que se acorta por la oración seca y contundente: "Muere de frío".

En definitiva, parece haber una tensión en relación a cómo pensar a este hombre y, a través de él, a todos los subordinados. Por un lado, el narrador apunta la idea de "hombre común", que cumple órdenes ${ }^{118}$; por otro están las permanentes insinuaciones en sentido contrario, que se ponen de manifiesto, como vimos, en las ambigüedades inscriptas en la palabra, en las ironías o aún en los silencios:

—¿Qué hacía usted en esa casa? — le preguntan a Di Chiano.

Qué iba a hacer... es mi casa.

— ¿Qué hacía?

Estaba con mi familia, escuchando la radio. (p. 109)

Sin ningún comentario del narrador, este pasaje reproduce el diálogo entre un interrogador y Di Chiano. Aquí queda explícito lo absurdo de la situación; y el narrador no comenta.

La construcción del perfil de Rodríguez Moreno se completa en el capítulo siguiente cuando este recibe la orden de fusilamiento. Al principio leemos:

\footnotetext{
${ }^{118}$ Hannah Arendt comenta sobre la última declaración de Eichmann, el criminal de guerra nazi, juzgado en Jerusalén: "Depois, veio o último depoimento de Eichmann: [...] a corte não o entendia: ele nunca tinha nutrido ódio aos judeus, e nunca desejou a morte de seres humanos. Sua culpa provinha de uma obediência... (Arendt, 2000, p. 269)
} 
4.45. Parece que Rodríguez Moreno estuviera tratando de ganar tiempo. No ha de resultarle muy agradable salir con semejante noche para matar a diez 0 quince infelices. (p. 113)

O sea, Rodríguez Moreno está tratando de ganar tiempo porque hace frío. Pero, además, a continuación, en el mismo párrafo se lee:

Personalmente está convencido de que más de la mitad no tiene nada que ver. Y aun otros le inspiran dudas. Nerviosos partes se cambian entre él y el jefe de Policía que ya ha llegado a La Plata. (p. 113)

El convencimiento de Rodríguez Moreno, las dudas, los nerviosos partes pueden distraer de los indicios que da el narrador de su postura frente a la actitud del policía. Observemos el adverbio "personalmente" y el uso del verbo "parecer", no solo aquí, sino también casi al final, cuando Fernández Suárez ha dado la orden de fusilamiento: "Parece que no basta. Fernández Suárez debe acudir personalmente al transmisor." (p. 114). Hasta aquí el narrador venía mostrando la problemática de Rodríguez Moreno, haciendo conjeturas y algunas afirmaciones y dando algunos indicios sobre su propia opinión. Pero el capítulo cierra con una oración corta y única, que hace que no queden dudas en relación a Rodríguez Moreno (para mayor claridad cito el pasaje completo):

...Fernández Suárez se dirige a un subordinado y en voz que todos escuchan da la orden:

_ iA esos detenidos de San Martín, que los lleven a un descampado y los fusilen!

Parece que no basta. Fernández Suárez debe acudir personalmente al transmisor.

Rodríguez Moreno recibe la orden. Inapelable

Y se decide. (p. 114) [el subrayado es mío]

Parecería que con la oración final está definido el perfil de Rodríguez Moreno. Pero no, el narrador volverá sobre él en los capítulos siguientes.

En este capítulo, “¡Fusilarlos!”, se cierra “la espera”; ahora los prisioneros serán cargados en un camión y llevados al basural. Este nuevo cambio de situación se refleja en varios 
aspectos. Uno de ellos se refiere al uso del sarcasmo y la ironía: el jefe de policía ahora es denominado solo por su apellido, Fernández Suárez, sin mención de cargo ni de "señor", porque ya no hay más espacio para juegos retóricos.

Otro cambio se refleja en el título de este capítulo. Desde “¿Dónde está Tanco?” hasta aquí en cada título está contenida la voz oficial; a veces indicada entre comillas, otras no; a veces son citas de palabras de la policía, a veces del gobierno. Mientras el clima de tensión crece entre los detenidos, los títulos anuncian otra cosa —“'Pónganse contentos”', “"Calma y confianza”"-; incluso “'A ver si todavía te fusilan...” está en tono de chiste. En cambio, el título de este capítulo, “¡Fusilarlos!”, es una "recreación” de la voz oficial: “ $A$ esos detenidos de San Martín, que los lleven a un descampado y los fusilen!" (p. 114), y contiene una síntesis del anuncio. Es como si fuese una bisagra entre esta primera parte y la que viene a seguir, en la cual los títulos ya no son sacados de la voz oficial. De aquí en adelante, prácticamente todos los títulos, en un juego metonímico, se referirán solo a un fragmento de lo que está contenido en el capítulo; como si cualquiera de los fragmentos sirviese para representar un todo quebrado y astillado.

\section{“La matanza"}

Entre “Le daba pecado..." y "El tiempo se detiene" se narra desde el traslado de los prisioneros al basural hasta la ronda del tiro de gracia, después del fusilamiento. La desintegración que traen el miedo y la muerte está en la forma de estos capítulos. Son cuatro, pero en cada uno habrá relatos de pequeños episodios que intentarán recomponer escenas de los momentos que rodean al de la matanza. La disgregación acentuará la inestabilidad de la voz narrativa y la búsqueda de un lugar de enunciación; hasta el fusilamiento, el narrador se preguntará sobre la posibilidad de culpa y arrepentimiento de los victimarios, una vez más mirando desde diferentes ángulos; "durante" la matanza, el punto de vista será el del miedo, el del terror de los prisioneros.

El viaje al basural, donde serán fusiladas las víctimas, está narrado en "'Le daba pecado...". Antes de dicho relato, abren el capítulo dos episodios, el primero de los cuales se refiere a la liberación de tres prisioneros que habían sido detenidos en la calle: 
“Rodríguez Moreno dirá más tarde que los liberó "'por su propia cuenta"' y que la orden de fusilamiento los incluía." (p. 115)

El segundo episodio, del cual es tomado el título del capítulo, se trata de un diálogo entre Miguel Ángel Giunta y el comisario Cuello que parece que a último momento quiere salvarlo:

Ya casi han subido todos. En ese momento sucede una escena curiosa. Es Cuello, que en un brusco impulso grita:

— iSeñor Giunta! [...]

Ahora hay casi un acento de súplica en la voz baja y reconcentrada de Cuello.

-Pero, Señor Giunta... - mueve un poco los brazos, con las manos crispadas _... Pero usted ¿estaba en esa casa? ¿Realmente estaba?

Giunta comprende en un relámpago que le está pidiendo que diga que no. [...] La cara de Cuello le sorprende: tensa, los ojos un poco extraviados, un músculo incontrolable palpitando en una mejilla ("Él sabía que yo era inocente. Le daba pecado mandarme a morir"...). [...]

_Sí, yo estaba. [...] (p. 116)

Observemos los calificativos para describir a Cuello, sus movimientos y sus gestos: "brusco impulso", acento suplicante, nerviosismo, tensión; hay algo que lo inquieta, algo que lo angustia; y el narrador lo registra. Pero, no puede pasar desapercibido lo de "brusco impulso"; o sea, el intento de salvar a Giunta se debió a un arrebato; del mismo modo que en la liberación de los tres prisioneros, el hecho de que Rodríguez Moreno decidiese "por cuenta propia" salvar a tres y no a todos parece tratarse de un acto irreflexivo y esto también lo registra el narrador.

En una primera lectura, el título “'Le daba pecado"” parecería que representa solo una parte de todo lo que contiene el capítulo. Sin embargo, la idea de pecado o de arrepentimiento $^{119}$ está contenida en cada episodio relacionado con la policía, cada vez que el foco se le dirige. Así al final del capítulo se relata otro "singular incidente" (p. 119): la descompostura del chofer que manejaba el camión rumbo al basural. Es como si el

\footnotetext{
${ }^{119}$ No pretendo ni puedo hacer una discusión religiosa. Tomo el sentido lego.
} 
narrador fuese juntando trozos de información, posibilidades de móviles para los actos; intentando indagar en las actitudes de los victimarios para darle una forma a lo incomprensible. En ese sentido se puede leer el párrafo siguiente:

Una cosa llama fuertemente la atención. Los policías van armados de simples máuseres. Para la misión que llevan, y en las circunstancias en que la van a cumplir, es casi incomprensible. ¿Se trata de una oportunidad, una "aliviada" que consciente 0 inconscientemente va a darles Rodríguez Moreno a los prisioneros? ¿O es que no existen fusiles ametralladoras en la Unidad Regional? Enigma de difícil respuesta. Lo indudable es que gracias a esa afortunada circunstancia [...] la mitad de los condenados salvarán la vida. (p. 117) [la cursiva es mía]

Se suman posibilidades y puntos de vista, pero el narrador no deja de parecer irónico. La posibilidad de la "aliviada" está rodeada de afirmaciones e hipótesis sobre los tipos de armas que hay en la comisaría; y la afirmación final, "Enigma...", con su guiño a la literatura policial, que juega entre lo encubierto artificialmente para dificultar la comprensión y lo que realmente no se alcanza a entender parecería dejar abierta ambas posibilidades; pero, la pregunta es: ¿sería realmente difícil averiguar si existían los fusiles ametralladora en la Unidad Regional? En realidad lo que todo ese pasaje pone en evidencia es que el hecho de que algunas personas salvaran la vida fue gracias al tipo de arma y no a un acto "conciente o inconsciente" de Rodríguez Moreno; el acto concreto de éste es que optó por llevar adelante el fusilamiento. Sin sutilezas y sin ironías, el narrador también se pregunta sobre la actitud de los detenidos. En el relato del viaje al basural, entre descripciones de itinerarios - las calles por las que pasa el convoy, las vueltas de la ruta- y conversación entre prisioneros — Brión y Giunta—, surge la duda en forma de afirmación: "Él [Livraga] es colectivero, conoce bien las rutas, tendría que darse cuenta de que no los llevan adonde dicen. Sin embargo, no observa nada." (p. 119). Ambas actitudes del narrador parecen indicar la misma estrategia de persuasión, comentada anteriormente, de los lectores del final de los años ' 50 .

El narrador vuelve insistentemente sobre el mundo interior de los policías; se pregunta, levanta hipótesis, busca entender. Así, en el capítulo siguiente, "El fin del viaje", todavía relata más episodios que muestran las vacilaciones de los policías y sus propias hipótesis: 
¿Es estupidez? ¿Es anticipado remordimiento? ¿Puede ignorar la zona? ¿Es un inconsciente impulso de buscar testigos para el crimen que va a cometer? ¿Quiere brindar una posibilidad "deportiva" a los condenados, librarlos al destino, a la suerte, a la astucia de cada uno? ¿Quiere de este modo absolverse, delegando el fin de cada cual en manos de la fatalidad? ¿O quiere todo lo contrario: apaciguarlos, para que resulte más fácil darles muerte? ( $p$. 121)

Todas estas cuestiones son levantadas ante la elección de un lugar "inadecuado" para el fusilamiento hecha por Rodríguez Moreno. Observemos que las preguntas sobre la actitud del comisario van de la estupidez a la maldad — pasando por el remordimiento, la ignorancia, la impulsividad-; después las dudas son sobre las intenciones: el comisario busca la absolución o "divertirse" porque es manipulador. Para cada una de estas indagaciones es necesario que el narrador ocupe diferentes lugares de enunciación e incluya diferentes puntos de vista.

Antes de llegar al lugar en que finalmente se llevará a cabo el fusilamiento, hay una parada intermedia. Y el relato también se retarda, se detiene en descripciones: por dónde bajan los prisioneros, quiénes bajan, cómo es el paisaje. El foco va de Rodríguez Moreno a Troxler y a los otros prisioneros. El desorden crece a medida que se aproxima el momento del fusilamiento; el desorden del asesinato se reproduce en una especie de "desconstrucción" de afirmaciones del narrador:

Bajan los mismos prisioneros. También Carranza y Gavino. Tal vez Garibotti y Díaz. Troxler afirmará luego que arriba quedaban con él Benavídez, Lizaso y el suboficial anónimo. (p. 123)

Después de "anónimo" hay una nota al pie de página (es la número 4):

O acaso "Mario N.", es decir Brión, cuyo apellido ignoraba Troxler. Pero otros sobrevivientes aseguraron que Mario bajó con ellos. La contradicción -típica de situaciones semejantes - permanece insoluble hasta ahora. (p. 175)

Si observamos detenidamente el primer párrafo vemos que hay una contradicción (para usar las propias palabras del autor): a la primera afirmación "Bajan los mismos prisioneros", oración corta y precisa, le sigue el "también" de la oración siguiente yuxtapuesta y sin conector; a continuación hay un "tal vez"; o sea, ya no son los mismos 
prisioneros que anuncia la primera oración. De la misma manera, a la afirmación de Troxler le sigue, en la nota al pie, un "o acaso..." esta vez proveniente de un narrador más distanciado.

En la sintaxis está representada la confusión del instante; en un mismo párrafo están presentes varias voces a la vez, incluso la propia del narrador, más distante, en la nota al pie de página. Lo mismo se puede decir en relación al lenguaje. Observemos el comentario "contradicción ... típica de situaciones semejantes": ¿a qué se refiere con "típica"? ¿y con "situaciones semejantes"? Parecería que la "desorientación" del momento relatado, cercano a la matanza, tomó por asalto al propio narrador.

"El fin del viaje" termina en el momento en que las víctimas están caminando por el borde del baldío mientras los vigilantes los empujan con los cañones de los fusiles y la camioneta policial les alumbra las espaldas. La última frase, "Ha llegado el momento...", se repite al comienzo del capítulo siguiente "La matanza". Allí se relata desde la "preparación" para el fusilamiento hasta el tiro de gracia dado a uno de los prisioneros (Vicente Rodríguez).

El foco del relato se alterna entre las víctimas que están en el basural y las que están en el camión: "A partir de ese instante el relato se fragmenta, estalla en doce o trece nódulos de pánico" (p. 125), dice el narrador. Y así también es la estructura del capítulo: la escritura vuelve una y otra vez sobre las víctimas; a veces es solo una frase, a veces un párrafo entero. La narrativa es rápida, con oraciones cortas. El narrador va identificando, con apellidos o nombres, uno a uno a los prisioneros, como intentando poner orden en el caos del momento. El relato pasa de un espacio a otro (basural / camión) cada vez que el foco se detiene en alguna de las víctimas que cayó en el fusilamiento.

La tricota de Brión brilla, casi incandescente de blanca.

En el carro de asalto Troxler está sentado con las manos apoyadas en las rodillas...

\section{$[\ldots]$}

Carlitos, azorado, sólo atina a musitar: 
—Pero, cómo... ¿Así nos matan?

Abajo, Vicente Rodríguez camina pesadamente por el terreno accidentado y desconocido... (p. 126)

A diferencia de los otros capítulos, en este hay concentración temática. El título hace alusión a lo narrado. El sustantivo "matanza", en su segunda acepción ${ }^{120}$, se refiere a la mortandad de personas en una batalla, en un asalto, etc.; pero en las otras acepciones siempre su significado está relacionado con la muerte de animales. Ese significado sumado a las metáforas "rebaño" o "arrear" - "Los vigilantes los arrean hacia el basural como a un rebaño aterrorizado." (p. 125) - dejan aparecer un deslizamiento en la condición de los prisioneros entre su naturaleza humana y animal. Aunque se trata de una metáfora de uso corriente, un clisé, cuando se trata de grupo de personas que se someten sin reacción a algún tipo de violencia, contrasta con otra usada unas páginas más adelante, después del fusilamiento: "El rebaño empieza a desgranarse" (p. 128), imagen nada común. Paralelamente a la oscilación en la condición de los prisioneros, la voz del narrador oscila entre usos coloquiales y usos cultos de la palabra.

El movimiento comenzado en "La matanza", el de reservar un espacio para cada una de las víctimas, se repetirá hasta el fin de "Los hechos"; aunque, a diferencia de la primera parte, cada capítulo estará dedicado a más de un protagonista, con un título que parece representar solo un fragmento del capítulo.

Así, por ejemplo, el tema de "El tiempo se detiene" es el tiro de gracia vivido, sufrido, por Don Horacio y Livraga. El ángulo del relato vuelve a ser el de las víctimas; las descripciones construidas con oraciones cortas y yuxtapuestas, en general tres; el estilo es nominal; las enumeraciones buscan la precisión; la repetición intensifica la sensación del miedo y detiene la acción:

Horacio Di Chiano no se mueve. Está tendido de boca, los brazos flexionados a los flancos, las manos apoyadas en el suelo a la altura de los hombros. Por un milagro no se le han roto los anteojos que lleva puestos. Ha oído todo - los tiros, los gritos - y ya no piensa. Su cuerpo es territorio del miedo que le

\footnotetext{
${ }^{120}$ Según el DRAE.
} 
penetra hasta los huesos: todos los tejidos saturados de miedo, en cada célula la gota pesada del miedo. (p. 131)

La detención del tiempo está en la propia forma: una primera oración corta y precisa, a continuación la yuxtaposición de tres oraciones que describen y dilatan el instante; la enumeración - “los tiros, los gritos”-; y la descripción demorada del miedo apropiándose del cuerpo, los tejidos, las células; todo en la forma del presente. $Y$ el comentario "por un milagro", locución adverbial de uso más corriente, representa un corte, una ruptura en la descripción, la misma ruptura que experimenta el cuerpo, "territorio del miedo", de Don Horacio.

El tono del fragmento correspondiente a Livraga es diferente. En el párrafo con que comienza se lee:

Más cerca de la ruta pavimentada, Livraga también se ha quedado quieto, pero infortunadamente para él en una posición distinta. Está caído de espaldas, cara al cielo, con el brazo derecho estirado hacia atrás y la barbilla apoyada en el hombro... (p. 133)

A diferencia del anterior, la descripción de la posición en que ha quedado Livraga empieza con la localización espacial y no hay referencias ni a los sentidos ni a los sentimientos. El propio adverbio "infortunadamente", que introduce el comentario indica una posición diferente del narrador, más distanciado.

En este capítulo el narrador da por finalizada la "Operación Masacre" (p. 133).

\section{El retorno (imposible)}

Después de "La matanza", el relato de los hechos acompaña las vivencias de los sobrevivientes del fusilamiento: el terror del tiro de gracia y la huida; la nueva detención y los muertos oficiales; y la "vuelta" a la vida cotidiana. Pero, después de esa experiencia de terror, el retorno es precario, incompleto: a algunos de los protagonistas todavía les faltan meses de sufrimiento a manos de las instituciones y para otros, el espanto del fusilamiento continuará en sus secuelas. Y eso está estampado en la forma "incompleta" del relato: títulos que anuncian lo que no vendrá, lenguaje que no alcanza, imprecisiones 
de forma y carencia de información. La narración no es lineal; está construida con avances y retrocesos temporales y espaciales al ritmo de la desorientación producida por el fusilamiento. Así como los prisioneros salen tambaleantes y aturdidos del basural para volver a sus vidas, así también es la narración, marcada por detalles y explicaciones que intentan volver, recuperar lo conocido; como si el contacto con lo familiar pudiese devolver a un lugar seguro y de equilibrio. Por eso, en toda esta parte, reconoceremos recursos de escritura ya usados anteriormente en Operación masacre, pero ahora produciendo otro efecto: acentúan el movimiento de la narración de llamar la atención sobre las técnicas.

En "El fin de una larga noche" se relatan los sucesos, posteriores al fusilamiento, vividos por tres de los sobrevivientes: Gavino, Giunta y Troxler. Dos de ellos, Gavino y Troxler, solo volverán a aparecer en el capítulo final de "Los hechos"; las peripecias de Giunta seguirán siendo narradas en capítulos posteriores. Los tres son los primeros que quedan más o menos "a salvo" después del fusilamiento: "La terrible aventura había terminado para él [Gavino]." (p. 135); "Y Giunta está —o se cree— a salvo." (p. 138); "Son las seis de la tarde cuando llega a un refugio seguro [Troxler]." (p. 139).

Las vivencias de Gavino y Giunta están relatadas en un mismo "bloque" (pp. 135-138), unidas por el hecho de que ambos sobrevivientes no son testigos del tiro de gracia y, además, llegan a un mismo destino: la estación de tren (Chilavert).

De Gavino sabremos cómo huyó del escenario de la masacre en un párrafo corto, con oraciones también cortas, yuxtapuestas y enumeraciones, que le dan al texto fluidez y velocidad, la misma de la carrera de este protagonista para ponerse a salvo. Su "vuelta" es el "asilo en una embajada latinoamericana." (p. 135).

La historia de Giunta es una "pesadilla inagotable", dice el narrador. Antes de ponerse momentáneamente a salvo, todavía vive otros episodios amenazantes, ahora ya no desde la institución policial: es amenazado por la dueña de una casa en el jardín en el cual busca refugio y es perseguido, o cree serlo, por tres desconocidos que toman el mismo tren que él. A partir de este capítulo, empiezan a alternar segmentos narrados en presente y en pretérito indefinido e imperfecto. En general el presente se mantiene para la noche del fusilamiento y la violencia oficial (torturas psicológicas y malos tratos a Giunta y 
Livraga, por ejemplo). Aquí, en particular, el pretérito es usado únicamente para contar este episodio de la mujer que amenaza a Giunta en el jardín de la casa.

Se reencuentra en este capítulo el lenguaje de la crónica policial que ya habíamos visto en la primera parte de Operación masacre: lo que parecería una especie de inadecuación para calificar los diferentes sucesos - "milagrosamente encuentra un colectivo", "terrible aventura", "aterrado fugitivo" (p. 135); "desesperada carrera" (p. 136), etc.-, dice el narrador describiendo y calificando la huida de ambos sobrevivientes, Giunta y Gavino.

El relato sobre Troxler está separado del anterior por un espacio mayor (marcado con asteriscos). Hay un corte también en la progresión de la acción. La narración de lo acaecido a los otros dos sobrevivientes comienza cuando ya están fuera del escenario del fusilamiento y se prolonga hasta que, en principio, están a salvo. La de Troxler es una vuelta al basural, después del tiro de gracia.

Y Troxler vuelve en busca de su amigo Benavídez. No lo encuentra. Después de identificar a varios de los muertos, se dirige a José León Suárez. Allí, presencia el momento en que un oficial de policía encuentra a Livraga herido. En un segundo episodio de la misma secuencia, soldados del Ejército lo interrogan sobre los tiros escuchados durante la noche:

[Troxler] Está por seguir de largo cuando ve que se acerca un camión con soldados del Ejército. Como siempre, Julio Troxler hace lo más natural: se dirige a una reducida cola de madrugadores que esperan un ómnibus de la Costera y se incorpora a ella. No piensa tomar el ómnibus —por otra parte no tiene ni cinco centavos-, pero sabe que ahí llama menos la atención.

Parece fatalidad. Porque el camión se para justo frente a la cola. Y sin bajar, un oficial grita:

—uuchachos, ¿ustedes no oyeron unos tiros?

La pregunta parece formulada a todos, pero es a Troxler a quien mira el oficial, es a él a quien se dirige, por un motivo muy sencillo: es el más alto de la fila. ( $p$. 139) [las cursivas son mías] 
En este fragmento podemos observar varias de las características señaladas anteriormente. El "Como siempre" indica una recuperación o una demostración de que a pesar de lo vivido esa noche, Troxler no perdió sus hábitos; pero, ¿cuáles son esos hábitos? ¿a qué se refiere el narrador con "como siempre..."? ¿Se refiere a algo que los lectores no sabemos y él sí? La falta de información contenida en esa afirmación intenta ser compensada haciendo explícitos enseguida una serie de detalles y explicaciones: se dirige a la cola y se incorpora; la cola es de madrugadores; el micro es el de la "Costera"; Troxler es el más alto, no piensa tomar el micro, no tiene dinero. Obsérvese también el contraste entre la idea de fatalidad y la explicación "por un motivo..." que rompe cualquier idea de misterio o fatalidad.

El título "El fin de una larga noche" sugiere más de lo que representa. Recordemos que la última oración del capítulo anterior anunciaba: "La masacre ha concluido." (p. 133); de esa manera, el título induce a pensar que se trata del fin de esa noche tenebrosa para todos los involucrados, y en realidad, como acabamos de ver, es el fin solo para algunos de los sobrevivientes. La contradicción entre título y capítulo, una vez más, parece estar acorde con lo contradictorio e incompleto de los vestigios de información.

Y las contradicciones se suceden. Una vez que Troxler "llega a un refugio seguro", el foco del narrador vuelve al basural, donde todavía se encuentra Livraga, en "El ministerio del miedo". Aquí se relata desde el momento en que Livraga oye la ejecución de Lizaso hasta que, momentos más tarde, es "rescatado" en el pueblo por un oficial de policía y llevado rumbo al hospital. En la línea de lo contradictorio, el párrafo inicial que describe las consecuencias físicas para Livraga del tiro de gracia, dice:

El "tiro de gracia" que le aplicaron a Livraga le atravesó la cara de parte a parte, destrozándole el tabique nasal y la dentadura, pero sin interesar ningún órgano vital. Su juventud y su buen estado atlético le prestaron un servicio incalculable: en ningún momento perdió el sentido, aunque el rostro se le iba hinchando y le dolía mucho. El intenso frío de la helada noche parecía mantenerlo despierto. (p. 141)

La pugna entre muerte y vida (el tiro que intenta matar y la resistencia física) está contenida en el extrañamiento que producen las comillas en "tiro de gracia"; siendo como es, una expresión normalizada y conocida, las comillas están indicando que el tiro fue y 
no fue de gracia. Así, de alguna manera, esta marca gráfica denuncia la insuficiencia de las expresiones conocidas para referirse a la masacre.

Retornar, en tiempo y espacio, al escenario del fusilamiento es retornar también en la forma de la escritura a la primera parte de Operación masacre marcada, entre otros recursos, por el presente. Así, en el párrafo que le sigue al antes transcripto (en pretérito), el relato de la muerte de Lizaso se hará en el presente; una vez más apuntando la actualidad y lo imborrable contenido en la violencia del fusilamiento. También nos reencontramos con el vaivén de afirmaciones e hipótesis, pero ahora más acentuadas; la inestabilidad de la voz narrativa se hace más explícita:

El infortunado muchacho no atinó a un gesto de fuga. O lo más probable, en el trance decisivo prefirió enfrentar valerosamente a sus ejecutores. (p. 141) [la cursiva es mía].

También se retoman la inversión sintáctica y los recursos de cohesión temáticos:

Cuando escucha los vehículos que se alejan, Livraga espera. Todavía no se mueve. Sólo cuando han transcurrido varios minutos trata de incorporarse. Apoya el brazo derecho en el suelo, tiene otro balazo. [las cursivas son mías]

En la oración en cursiva, la simultaneidad de escuchar y esperar en vez de estar indicada por la conjunción "mientras" lo está por "cuando"; esta estructura nos prepara para algo que no llega.

Algo semejante se puede decir del título, "El ministerio del miedo", que señala un camino de lectura del capítulo diferente de lo que contiene. Es un título parcial, no contempla el encuentro con "un ser humano" (p. 142), que alivia, aunque sea momentáneamente la tensión del relato:

...Está exhausto. Va a caer. Alguien alcanza a tomarlo entre sus brazos.

Es un oficial de policía.

En ese momento debió pensar Livraga en una pesadilla infinita donde fuera cíclicamente arrestado, fusilado, arrestado, fusilado... 
Sin embargo, se había encontrado al fin con un ser humano. (p. 142) [las cursivas son mías]

Este episodio, de la manera que está narrado, parece independiente del relatado en el capítulo anterior: el pronombre ("alguien") y el artículo ("un"), ambos indefinidos, inducen a pensar de esa forma. Sin embargo, los lectores sabemos que ese oficial de policía es el mismo que se menciona en el capítulo anterior, que conoce a Troxler y que encuentra a Livraga. $Y$ es eso lo que nos recuerda el narrador en la oración siguiente:

El oficial —a quien ya hemos visto saludando Troxler- ni siquiera le preguntó por qué estaba herido. (p. 142)

La aclaración de quién es el oficial, entre guiones, rompe abruptamente lo que se venía construyendo; este movimiento parece apuntar una oscilación entre suscitar y mantener un "misterio" y no hacerlo. En este recurso no hay ningún "disimulo", ningún adorno. Se rompe la armonía; las fisuras, propias de la historia real, le dan la estructura.

Y por fin llegamos al último capítulo en el basural, "Una imagen en la noche", especie de collage en el que se suman episodio tras episodio: la salida de Don Horacio del "tétrico escenario", las incógnitas sobre el sargento Díaz y el "suboficial X", el espanto de los vecinos frente a los cadáveres y la remoción de los cuerpos; y dos episodios "menores": el de una mujer cuyo coche es apedreado al manifestar su desprecio - y su aprobaciónfrente a la escena de los cuerpos tirados en el basural; y el del sereno del policlínico donde fueron trasladados los cuerpos, quien compara a Brión con "un Cristo".

El capítulo está dividido en tres partes, separadas por espacios mayores y marcadas con asteriscos. En la primera se cuenta desde que don Horacio "alzó la cabeza", después del tiro de gracia, hasta que entra en un bar, en Liniers ${ }^{121}$, y está a salvo. Como antes, el tiempo del relato es el presente de la escritura y el pretérito para lo que transcurre después del fusilamiento: "Don Horacio ignora [hasta hoy, presente de la escritura] cuánto tiempo estuvo [en aquel momento] haciéndose el muerto. (p. 145)". El estado de espíritu y la desorientación de Don Horacio a la salida del basural, registrada en múltiples detalles

\footnotetext{
${ }^{121}$ Gran Buenos Aires.
} 
(la dificultad para atravesar zanjas, confusión de colores y números, el boleto capicúa ${ }^{122}$, el café que no puede tomar y el que puede), parece tomar al narrador cuando cuenta sobre la ilusión óptica ${ }^{123}$ de Don Horacio:

Incidentalmente, el detalle probó a quien esto escribe — por si alguna duda me quedaba - que don Horacio había estado allí. (p. 145)

El adverbio "incidentalmente" - accidentalmente, por casualidad — contradice la nota número 7:

Me había intrigado mucho ese rasgo topográfico, que don Horacio mencionaba y que yo nunca lograra observar en mis tres o cuatro visitas al basural. Hasta que fui un día con él. Y de pronto, tras buscarlo ambos un buen rato, lo vi. [...] En ese momento supe — singular demostración-que me encontraba en el lugar del fusilamiento. (p. 175) [el subrayado es mío]

Es decir, no hay casualidad, al narrador le llamó la atención y fue a buscarlo. También podemos leer como representación del aturdimiento la oscilación entre la primera persona y la tercera - "a quien esto escribe" / "me quedaba"-; la voz narrativa no está segura del lugar desde el cual referir los sucesos. En la "inestabilidad" de la voz narrativa que, como ya fue apuntado, recurre frecuentemente a las citas al pie de página, se percibe la necesidad de apoyarse en la autoridad, dejando ver la tensión entre realidad y ficción.

La misma oscilación se repite en la segunda parte de "Una imagen en la noche"; son dos párrafos de dudas, conjeturas y afirmaciones sobre lo que el narrador no sabe con respecto al sargento Díaz y el "suboficial X". A modo de conclusión hay un tercer párrafo, que es una especie de balance: "Cinco muertos seguros dejó la masacre, un herido grave y seis sobrevivientes." (p. 147). Pero el capítulo continúa.

La tercera parte registra la reacción de la población frente a los cadáveres, la retirada de los cuerpos y la impresión del sereno del policlínico donde fueron llevados. La narración

\footnotetext{
${ }^{122}$ Los boletos de ómnibus, en Argentina, tienen un número. Ese número es capicúa cuando se lee igual de izquierda a derecha que de derecha a izquierda. La creencia popular dice que sacarse un boleto capicúa es señal de buena suerte.

${ }_{123}$ Después del fusilamiento y cuando ya amaneció, Don Horacio cree ver un árbol en el horizonte, pero en realidad son varios.
} 
avanza muy despacio; ocupa unas dos horas reales: desde que amanece (a las 7:57) hasta que retiran los cuerpos del lugar (a las 10:00 de la mañana). Describe el espacio donde estaban los cadáveres: su distribución, la sangre, las marcas de los balazos.

El título de este capítulo hasta la segunda edición era "Una imagen en la morgue", que aludía sin ambigüedad a la imagen de Mario Brión como un cristo, sensación del sereno del policlínico al que fueron trasladados los cuerpos de las víctimas. Aunque ahora la idea de "imagen" acompaña a cada una de las partes relatadas, el nuevo título, "Una imagen en la noche", no corresponde exactamente a ninguna de ellas; si se refiere al árbol que ve don Horacio al levantar la cabeza, eso sucede al amanecer; si se refiere a la imagen de Mario, el sereno ve el cuerpo a la tarde.

Esta discrepancia entre título y contenido del capítulo parece modificarse en “Te llevan”". Aquí se narra desde las horas posteriores al fusilamiento hasta la nueva detención de Livraga y Giunta. Al igual que en los capítulos anteriores, ambas partes están relatadas por separado pero aquí lo que las relaciona es la nueva detención. El oficial que encuentra a Livraga lo lleva al Policlínico de San Martín. Allí, le hacen las primeras curas y, después de algunas horas, la policía viene a llevárselo nuevamente. "Pibe, te llevan'” es lo que le dice una enfermera llorando (p. 151). El caso de Giunta es similar porque aunque él decida entregarse, también "se lo llevan".

La similitud de situaciones para ambos sobrevivientes parece estar reforzada por un recurso gráfico: el uso de la letra cursiva en ambas partes del capítulo:

El policía, entretanto, busca algo. El recibo. Pide las ropas de Livraga. No se las dan. Se vuelve fastidioso... (p. 150)

Livraga ya no resiste, ya no protesta. Cuando esa noche lo ponen en una camilla y una enfermera le dice llorando: "Pibe, te llevan", ya está vencido. Tanto penar para morirse uno. (p. 151)

En los cambios de guardia se producían conversaciones en voz baja [...]

_Esta noche "sale"... [Giunta]—murmuraba uno.

— ¿Para dónde? — contestaba otro con una risita. (p. 152)

A los dos o tres días de su encierro [el de Giunta], fue a verlo Cuello [...] Ahora no podía dar crédito a sus ojos. Le parecía estar viendo a un fantasma. 
—Pero, ¿cómo lo hizo? —repetía—. ¿Cómo lo hizo? (p. 153)

En cada una de las citaciones hay alguna marca que nos permite pensar que la cursiva indica algo que se repite. En la primera, el policía se "vuelve fastidioso" y exige "el recibo". En la segunda, la alusión al poema de Miguel Hernández, "Umbrío por la pena” ${ }^{124}$, es más difícil de saber de quién proviene: ¿de Livraga o del narrador? Los datos que tenemos sobre Livraga son que "sus ideas son enteramente comunes, las ideas de la gente del pueblo, por lo general acertadas con respecto a las cosas concretas..." (p. 67); que abandonó la escuela, que fue oficinista y que ahora trabaja como colectivero; estos datos no implican que esas palabras no fuesen de conocimiento general adquirido en la escuela, en los periódicos, etc. Pero, también puede indicar un recuerdo recurrente en la memoria del narrador. Una posible respuesta, ambigua, la encontramos en la primera edición de Operación masacre que dice: "Tanto penar para morirse uno, pudo haber dicho con el poeta español que algo supo de esto." (WALSH, 1957, p. 93). Digo "ambigua" porque la elección del indicativo en lugar del condicional, en "pudo haber dicho", plantea la duda de si lo dijo o no.

En la tercera de las citaciones anteriores, referida a Giunta, el pretérito imperfecto señala la habitualidad de los diálogos; en la cuarta, es la propia repetición, además del verbo de comunicación "repetir". Esta forma de resaltar lo que se repite parece aludir a un deseo de dejar registrada la posibilidad de un retorno a algo familiar, aunque ahora se trata de lo familiar "extraño"125.

Este extrañamiento se reproduce también en el aspecto temporal. El relato en este capítulo comienza con el pretérito indefinido, pero rápidamente, en el caso de Livraga, vuelve al presente para registrar sus vivencias tanto en relación a la solidaridad de las enfermeras como a la brutalidad policial. La segunda parte del capítulo está casi

\footnotetext{
${ }^{124}$ Umbrío por la pena, casi bruno, / porque la pena tizna cuando estalla, / donde yo no me hallo, no se halla / hombre más apenado que ninguno. // Pena con pena y pena desayuno, / Pena es mi paz, y pena mi batalla, / Perro que ni me deja ni se calla, / Siempre a su dueño fiel, pero importuno. // Cardos, penas, me oponen su corona / Cardos, penas, me azuzan sus leopardos / Y no me dejan bueno hueso alguno. // No podrá con mi pena mi persona, / Circundada de penas y de cardos. / ¡Cuánto penar para morirse uno!. Hernández Miguel. Antología. Buenos Aires, Losada, 1996, pp. 38-39. El poema pertenece a "El silbo vulnerado", de 1934.

125 "Familiar extraño" es la definición freudiana de lo siniestro. Sigmund Freud, Obras completas, vol. XVII, "Lo ominoso", Amorrotu, Buenos Aires, '988.
} 
totalmente en pretérito; el único momento en que se relata en presente, se produce una incoherencia:

Giunta, que hasta ese momento se había portado con toda lucidez, ahora comete una tontería. Quiere presentarse a aclarar su situación.

Fue a entregarse a la casa paterna. (p. 151) [la cursiva es mía]

"Comete" afirma la realización de algo, mientras que "quiere" expresa el deseo, la intención de hacer algo ${ }^{126}$. Pero, puede ser que el narrador esté pensando en el hecho de que "fue a entregarse"; aquí, entonces, la incoherencia se daría en la concordancia temporal.

Aun en esa citación, el hecho de que el deseo de Giunta sea calificado como "una tontería" puede indicar el comienzo de un cambio de actitud en el narrador: este ya no necesita destacar la inocencia de las víctimas y discutir la posibilidad de la existencia de justicia; definitivamente, entregarse es un error. Esta hipótesis de interpretación se afirma remitiéndonos a la primera edición. En lugar de la citación anterior, leemos:

Giunta hizo lo que haría cualquier hombre que se sabe inocente en un país civilizado: presentarse a aclarar su situación. Fué ${ }^{127}$ un tremendo error. (1957, p. 93)

Que puede tratarse del comienzo de un cambio de actitud en el narrador también queda confirmado cuando comparamos algunos cambios que se producen a partir de la segunda edición. Por ejemplo, lo que acontece con Giunta está enmarcado, a partir de 1964, por comentarios sobre las intenciones de los policías que lo mantenían en cautiverio. Si bien los comentarios del narrador van de la afirmación contundente a la duda, veremos que en la primera edición, aunque seguía la misma secuencia, las afirmaciones eran mucho más mediadas. Así, a partir de la edición de 1964, se lee:

Lo empujaban deliberadamente a la locura. (p. 152)

Parece que lo incitaban a la fuga. Al fin y al cabo no era tan difícil. No estaba en un verdadero calabozo. (p. 152)

\footnotetext{
${ }^{126}$ El uso del pasado "cometió" y "quiso" no llevarían a esta incoherencia.

${ }^{127}$ Mantengo la ortografía original.
} 
Acaso lo incitaban al suicidio. En una oportunidad lo pasaron a otro cuarto del primer piso, con ventanal al patio.

-Y no se le ocurra escaparse por ahí —le dijo un oficial, señalando la accesible ventana. (p. 153)

La primera oración aparece sola en el texto, como párrafo, es decir es una afirmación en posición destacada. Está colocada entre pequeños episodios que describen las torturas psicológicas perpetradas por los policías que rodean al detenido. Las otras dos encabezan diferentes párrafos, y son explicadas a continuación. Tanto "parece" como "acaso" introducen un matiz de duda que no tiene la primera.

Si nos remitimos a la primera edición, en ella se leía:

Más de un detalle permite suponer un plan en la conducta policial. Habían descubierto el punto débil de Giunta —sus nervios - y lo empujaban deliberadamente a la locura, para anularlo como testigo. (1957, p. 94)

Aquí, la afirmación "lo empujaban..." está mucho más mediada que en la versión que aparece a partir de 1964; está precedida por una suposición y una explicación; y cierra con un motivo. En la edición de 1957 el narrador necesitaba explicar; a partir de 1964 su visión de mundo se va haciendo explícita en los epílogos e implícita en la forma del texto.

De cualquier forma, estas tensiones —entre la afirmación y la duda—, que se producen sobre todo en los fragmentos en que se relatan pasajes de "la historia de nuestra barbarie" (p. 151), parecen indicar la resistencia del narrador a creer que se hayan perdido los parámetros de civilización; que sea posible que la perversidad atraviese las instancias del Estado.

El cambio de actitud del narrador — su paulatina descreencia en la justicia — también se refleja en un cambio de lugar en relación a lo narrado. "Un muerto pide asilo" es un capítulo destinado a mostrar el absurdo y la arbitrariedad de los procedimientos oficiales. La premisa es que en "la ciega irresponsabilidad con que se procedió desde el principio hasta el fin en esa operación clandestina calificada de fusilamiento" (p. 155) se hallarían 
explicaciones para lo que sucede después de la masacre: en la lista oficial, se dan por muertas personas que no lo están y viceversa, y algunos de los apellidos de los muertos aparecen equivocados:

A Benavídez, que gozaba de perfecta salud tras huir del basural de José León Suárez, lo daban por muerto. A Brión, en cambio, que había caído, no lo mencionaban en absoluto. A Lizaso lo llamaban "Crizaso"; a Garibotti, “Gariboto". (p. 155-156)

Al principio del capítulo se lee el relato de los hechos que justifican el título: Benavídez, uno de los sobrevivientes, que había sido dado por muerto oficialmente, se exilia en Bolivia. Empieza con una pregunta, “¿Había muerto Benavídez?” (p. 155), que dará pie al narrador para explicitar sus intervenciones. Hará hipótesis: "El más asombrado debió ser él mismo...”; calificará: “...sin embargo, la explicación era muy simple.”; opinará: "Parece mentira que se puedan cometer tantos errores...”; comentará en general:

Lo curioso es que ninguno de estos macabros errores ha sido rectificado, aun después que yo los denunciara. (p. 156)

El "yo" comienza a destacarse a partir de este capítulo, es un "yo" más cercano a la voz del autor. Está aquí y en una de las notas al pie de página (la 10): "El asesinato de Mario Brión fue denunciado por primera vez por mí en Revolución Nacional..." (p. 176). El narrador que hasta este momento se colocaba en diferentes lugares en relación a sus protagonistas, pero siempre dejándolos en primer plano, empieza ahora a ocupar más espacio. Es el lugar de indagación.

$\mathrm{Y}$, tal vez, justamente por tratarse de indagación es que aquí también se acentúan las inestabilidades en la voz narrativa. En la nota 9, después de la transcripción de un trecho de la declaración que Troxler y Benavídez le enviaron a Walsh desde Bolivia, se lee: "Declaración [...] dirigida al autor de este libro." (p. 176); o sea, el narrador designa al autor en tercera persona. 
El cambio de actitud del narrador también se refleja en sus manifestaciones de indignación. Este capítulo, "Un muerto pide asilo", se divide en cinco partes ${ }^{128}$ y, salvo la primera, cada una de ellas muestra el trato dado por la policía a los familiares de los muertos en el basural. Va de lo general - "A los familiares de las víctimas no se les ahorró molestias, vejación ni incertidumbre alguna." (p. 156) - a lo particular: a un hermano de Carlos Lizaso lo hacen deambular de comisaría en comisaría sin que nadie le informe la verdad; a la esposa de Vicente Rodríguez la tratan de ignorante antes de comunicarle el fusilamiento de su esposo; a un hijo de trece años de Francisco Garibotti, que no sabía sobre la muerte de su padre, se lo comunica el indolente chofer de Fernández Suárez; con la hija de Nicolás Carranza acontece algo parecido.

La indignación frente al abuso perverso de las instituciones queda registrada en descripciones y opiniones del narrador; el lenguaje es asertivo y la adjetivación clisé, que antes remitía a la crónica policial, ahora es un indicador de la insuficiencia de palabras para nombrar la violencia que se ejerce sobre los familiares de las víctimas:

Un hermano de Lizaso, que por versiones sospechaba su trágico fin, estuvo ambulando de comisaría en comisaría en busca de noticias concretas... [En la Unidad Regional San Martín] tuvieron el sangriento cinismo de decirle que no conocían a Carlitos y mandarlo, en una búsqueda que de antemano sabían estéril, a la Brigada de Investigaciones. (p. 156) [la cursiva es mía]

Tal vez, también sea la indignación lo que mueva al narrador al uso más frecuente de segmentos dramatizados para diálogos en los que interviene algún policía.

— ¿Usted es analfabeta? —preguntó despectivamente [a la esposa de Vicente Rodríguez].

Conste aquí. Consten las ventajas que da el alfabeto para martirizar a una pobre mujer.

La contundencia, el poder de síntesis y, en este caso, la precisión que traen las frases cortas, recreadas en estilo directo, sumadas a la ironía ponen en lugar destacado la crueldad policial.

\footnotetext{
${ }^{128}$ En la edición que manejo, no hay separación gráfica entre la parte que se refiere a Benavídez y la que le sigue, referida a Lizaso; sin embargo, sí la hay en las ediciones originales.
} 
Las intervenciones del narrador se hacen cada vez más explícitas también en el comentario irónico. En el capítulo siguiente, "La guerrilla de los telegramas", se relata el cautiverio de Livraga y Giunta, los dos sobrevivientes que volvieron a ser presos, y la lucha de las respectivas familias por encontrarlos. El capítulo está dividido en dos partes y el primer indicio irónico ya está en el título, que hace referencia al contenido de solo una de ellas: la lucha de la familia Livraga por encontrar a su hijo. Pero además, el título representa una parte de la parte; lo que se destaca en este capítulo, en realidad, es el tratamiento que sufrió Juan Carlos Livraga durante su cautiverio.

La palabra "guerrilla", a nivel léxico, lleva implícita la idea de grupos pequeños, ataque sorpresivo, conocimiento de terreno ${ }^{129}$. Probablemente haya sido una sorpresa para el gobierno la osadía del padre de Livraga, que se atrevió a enviar un telegrama para interceder por la vida de su hijo; pero don Livraga no conocía el terreno. La idea asociada a "grupo pequeño" solo quedará clara en el capítulo siguiente, pues en este sólo se mencionan y transcriben dos telegramas: uno del padre de Juan Carlos Livraga y el otro del "Jefe Casa Militar".

La primera parte del capítulo (que es continuación de la primera de "Te llevan"') comienza: "Entretanto, se estaba librando una sorda batalla por la vida de Juan Carlos Livraga." (p. 163). El relato que le sigue va a mostrar cómo se lleva a cabo dicha "sorda batalla". En una primera lectura, podríamos creer, inducidos por el título, que la batalla es por la vida, y que es la que libra la familia de Livraga; sin embargo, nos encontramos con el siguiente párrafo como continuación de la oración inicial:

Del policlínico un jeep conducido por el comisario inspector Torres lo lleva a la Comisaría $1^{a}$ de Moreno, donde lo arrojan desnudo en un calabozo, sin asistencia médica y sin alimentos. No le dan entrada en los libros [de la Comisaría]. ¿Para qué? Probablemente están esperando capturar a los otros fugitivos para volver a fusilarlos con más tranquilidad. $O$ quieren que se muera solo. (p. 163) [la cursiva es mía]

\footnotetext{
${ }^{129}$ Dice la definición del Clave: "grupo de personas armadas no pertenecientes al ejército que, al mando de un jefe particular y aprovechando su conocimiento del terreno y su facilidad de maniobra, luchan contra el enemigo mediante ataques sorpresa."
} 
Este párrafo más que una batalla por la vida registra la batalla por la muerte con sus imágenes de violencia y desamparo. Con la pregunta retórica e irónica, “¿Para qué?”, el narrador está "explicando" y recordándole, al buen entendedor, que el trámite legal en una detención es apuntarlo en los libros. La misma interpretación, en el sentido de lo irónico, se le puede dar al uso del sustantivo "tranquilidad" — no se refiere a un fusilamiento en orden, sino a llevarlo a cabo con tiempo, sin nerviosismos ni agobio, sin preocuparse por quedar bien o mal ante la opinión pública-. Pero como se está hablando de ilegalidad, de malos tratos, de torturas físicas y psicológicas, la ironía "graciosa" es difícil de mantener, de ahí las hipótesis ("probablemente", "o") y la crudeza del "que se muera solo".

Y a medida que nos vamos aproximando al final el narrador se vuelve más contundente en sus conceptos sobre el perfil de los policías, aunque todavía se filtren imprecisiones en su escritura. En un pasaje que relata el momento en que un comisario le lleva una manta a Livraga, quien está herido y no es curado ni alimentado, dice así:

Nada tendríamos que decir en defensa del entonces comisario de Moreno, Gregorio de Paula. Es inútil que un hombre pretenda escudarse en "órdenes superiores" cuando estas órdenes incluyen el asesinato lento de otro hombre inerme e inocente. (p. 165) [la cursiva es mía]

O sea, ahora el narrador enuncia claramente que órdenes superiores no justifican la perversidad. Sin duda el narrador cuenta con el acuerdo pragmático del lector para interpretar correctamente la oración marcada en cursiva. (¿Podría escudarse en "órdenes superiores" si el asesinato no fuese lento? ¿podría hacerlo si el asesinato lento no fuese el de un hombre desarmado? ¿o si el asesinato lento fuese el de un hombre no inocente?). Los adjetivos "lento", "inerme", "inocente" destacan las condiciones en las que se lleva a cabo la tortura moral de Livraga pero, además, colocados como están generan extrañeza.

Y la extrañeza crece al leer pasajes como el siguiente:

[Juan Carlos] Sobrevive prodigiosamente a sus heridas infectadas, a sus dolores atroces, al hambre, al frío, en la húmeda mazmorra de Moreno [...] Cuando acaso por piedad le dejan a la puerta las sobras del rancho, y se arrastra como un animalito hacia ellas, comprueba que no puede comer, que su 
destrozada dentadura guarda todavía lacerantes posibilidades de dolor... (p. 165) [la cursiva es mía]

Este fragmento tiene algo de exagerado en su construcción: obsérvense adjetivos, sustantivos, adverbio; la comparación de la celda con una mazmorra, con todo lo que evoca esa palabra; y los diminutivos "animalito", "pedacitos" y la repetición de la idea del "leproso de la Revolución"; todo esto junto en un único párrafo, sin duda traen a la memoria la animalización. Pero también llama la atención del lector por lo exagerado del lenguaje.

Y no para por ahí. En la segunda parte del capítulo, dedicada a Miguel Ángel Giunta, se refuerzan los elementos animalescos. Se relata el cautiverio y los segmentos finales están dedicados a la "odisea" familiar para encontrar a Miguel Ángel. Hay varios párrafos que muestran el estado mental de Giunta y, como en la parte anterior, también hay trechos dedicados al modo de actuar de la policía, visto tanto a través de lo que revive el preso, como en el trato que le dan. Ya no lo torturan psicológicamente, pero tampoco le dan de comer ni de beber. Quienes salvan a Giunta de morir de hambre y sed son los presos comunes, que han ideado mecanismos para alimentarlo:

A través de la mirilla de la celda le tiran mendrugos de pan y sobras de alimentos que el prisionero recoge ávidamente del suelo. Para mitigar su sed, discurren un procedimiento de emergencia. Introducen por el agujero el pico de una pava y el sobreviviente bebe a tientas el chorro de agua que cae. (p. 167)

La palabra "celda" y la acción de "tirar" mendrugos y sobras evocan la idea de lo animal y de la mendicidad. Ambos elementos junto con la escena final, cuando sacan a Giunta de la Unidad Regional para llevarlo a Olmos, trae a la memoria el esperpento:

Allá va el extraño grupo, a las doce del día, por las arterias céntricas de la ciudad de San Martín: el "temible" preso, los armados esbirros y los llorosos familiares que los siguen. La gente contempla asombrada este espectáculo. (p. 168)

Y otra vez la ironía y la ridiculización y el señalamiento de los recursos, entre comillas, o con la oración asertiva que cierra el párrafo. 
Y así llegamos al último capítulo del relato de los hechos. "Lo demás es silencio..." se divide formalmente en dos partes. La primera es continuación del capítulo anterior y relata la estadía de Giunta y Livraga en el penal de Olmos; la segunda, es un recuento de las consecuencias de la masacre, "el saldo".

Ambas partes contienen un final: el primero corresponde al día que Livraga y Giunta salen de la cárcel y en la Jefatura de Policía de La Plata les expiden la orden de excarcelación; en ella, "en el rubro 'Causa', había una expresiva línea de guiones escritos a máquina” ( $p$. 171). El narrador lo comenta:

Sin causa, en efecto, se había pretendido fusilarlos. Sin causa, se le había torturado moralmente hasta los límites de la resistencia humana. Sin causa, se lo había engrillado y esposado. Y ahora sin causa, en virtud de un simple decreto que llevaba el $\mathrm{N}^{0} 14.975$, se lo restituía al mundo. (p. 171-172)

El segundo final es un balance y una revelación. Un balance de las consecuencias que trajo consigo la violencia sufrida por los protagonistas; una especie de resumen que, a la manera de algunas películas, registra, después del cartel que anuncia "fin", qué pasó con sus protagonistas. La alusión al género cinematográfico me hace pensar en la alusión a la tragedia, contenida en el título, "Lo demás es silencio" — palabras finales de Hamlet $^{130}$, antes de morir-.

La "revelación"131 se le aparece al narrador en una hojita de papel con "fecha varios meses posterior al 9 de junio de 1956":

Dieciséis huérfanos dejó la masacre [...] Esas criaturas en su mayor parte prometidas a la pobreza y el resentimiento, sabrán algún día [...] que la Argentina libertadora y democrática de junio de 1956 no tuvo nada que envidiar al infierno nazi.

Pero lo que a mi juicio simboliza mejor que nada la irresponsabilidad, la ceguera, el oprobio de la "Operación Masacre" es un pedacito de papel. Un

\footnotetext{
${ }^{130}$ Esta alusión a Hamlet en el capítulo final de "Los hechos" es otro movimiento irónico de la narrativa: en Operación masacre no hay "héroe trágico", solo excluidos de la comunidad; y esta exclusión no devuelve a la comunidad, a la armonía perdida; al contrario.

${ }^{131}$ Aquí pienso en Semprun (La escritura o la vida) y en Ferreira Gullar (Rabo de foguete). Para ambos, también en un pedacito de papel se revela un equívoco, que de cualquier forma no explica la naturaleza de la violencia que sufrieron.
} 
rectángulo de papel oficial de $25 \mathrm{~cm}$ de alto por 15 de ancho. Tiene fecha varios meses posterior al 9 de junio de 1956 y está expedido, después del trámite previo en todas las policías provinciales, incluso la bonaerense, a nombre de Miguel Ángel Giunta, el fusilado sobreviviente. Sobre el fondo de un escudo celeste y blanco, constan su nombre y el número de su cédula de identidad. Arriba dice: República Argentina - Ministerio del Interior - Policía Federal. Y luego, en letras más grandes, cuatro palabras:

"Certificado de Buena Conducta." (p. 173-174)

El "pero" con el que comienza el párrafo anterior nos prepara, tal vez, para algo más contundente inducido por el recuerdo de la experiencia del nazismo. En lugar de eso, vienen tres sustantivos para calificar la operación masacre, que, salvo el último, son de uso muy corriente. Es como si el narrador tuviese dos "sentimientos" en relación a lo que pasó: por un lado, la intuición ${ }^{132}$ que lo lleva a igualar el fusilamiento a la experiencia nazi -no es la única vez que aparece dicha comparación-, que como sabemos se trató de un exterminio pensado y rigurosamente planificado desde el Estado; por otro, define la masacre como una operación irresponsable, ciega y oprobiosa; adjetivos, estos, que giran alrededor de la falta de previsión o meditación; de la alucinación, del ofuscamiento de la razón; del deshonor, de lo indigno.

La explicación de este vaivén puede encontrarse en las declaraciones hechas a la revista Siete días, en 1969. Ante la pregunta del entrevistador sobre "las técnicas distintas en sus libros 'periodísticos', Operación masacre y ¿Quién mató a Rosendo?, Walsh responde:

En Operación masacre yo libraba una batalla periodística "como si" existiera la justicia, el castigo, la inviolabilidad de la persona humana. Renuncié al encuadre histórico al menos parcialmente. Eso no era únicamente una viveza; respondía en parte a mis ambigüedades políticas. ¿Quién mató a Rosendo?, en cambio, es una impugnación absoluta del sistema y corresponde a otra etapa de formación política. (WALSH, 1996, p. 119)

Ante estas afirmaciones, válidas para 1957, habría que hacerse la pregunta: ¿y después? Parecería que no hay respuestas satisfactorias para la violencia estatal. También hay en

\footnotetext{
132 Intuición que se transforma en seguridad en "Aramburu y el juicio histórico", último capítulo escrito para Operación masacre, en 1973. Allí podemos leer sobre Aramburu: "Ejecutor de una política de clase cuyo fundamento - la explotación - es de por sí antihumano y cuyos episodios de crueldad devienen de ese fundamento [...] Aramburu estaba obligado a fusilar y proscribir del mismo modo que sus sucesores [...] por el simple hecho de que representan a una minoría usurpadora que sólo mediante el engaño y la violencia consigue mantenerse en el poder." (p. 237)
} 
ese final una marca de resistencia: por un lado, a creer que sea posible repetir la experiencia nazi; por otro, a darle todo ese poder simbólico a la institución policial. Es el propio contenido del párrafo el que induce esta lectura: una descripción detallada de "un pedacito de papel". Con el diminutivo está simbolizando a qué quedó reducido el valor de las instituciones que lo otorgan.

El trabajo de lectura hecho hasta aquí indica que la segunda parte de Operación masacre está marcada por la búsqueda de la voz narrativa de un lugar de enunciación; esa búsqueda está determinada porque la voz tiene que enunciar, anunciar, narrar el acto de matar promovido desde el Estado. Los límites de la palabra para nombrar esa violencia determinan dos movimientos en la narrativa. Uno es el registro de menudencias que intenta recomponer, recuperar lo perdido en el acto de muerte. Otro movimiento es el del narrador que, buscando dar cuenta de los hechos, prueba diferentes perspectivas: la de las víctimas, la de los victimarios y aun la propia, en sus varias instancias asociadas: la de narrador-periodista, la de narrador-autor. Esos ensayos de lugar de enunciación producen una tensión entre las diferentes instancias de la voz narrativa: entre el lugar del narrador y el de la voz del autor; se produce una inestabilidad de voces.

La multiplicidad de perspectivas y la inestabilidad de las instancias del narrador, al dejar al descubierto — con fisuras y grietas - los rastros de construcción del punto de vista de la narración, explicitan un movimiento de resistencia al discurso autoritario, aparentemente sólido, de las instituciones del Estado.

\subsection{CÓMO PERSUADIR A LOS LECTORES: "La evidencia"}

Si la primera y segunda partes de Operación masacre están construidas a partir de la arbitrariedad del fusilamiento, esta tercera ${ }^{133}$ lo está con la idea demostrar que no se trató de un fusilamiento ejecutado en cumplimiento de la ley sino de un crimen y un crimen cometido por el Estado. El texto construye la demostración apropiándose de la "narrativa" de los representantes de las instituciones estatales y refuta los relatos de los hechos que

\footnotetext{
133 Aquí no considero ni el "Epílogo" ni el último capítulo, “Aramburu y el juicio histórico", que serán comentados en el próximo apartado, 3.5.
} 
enuncian desde los culpables "menores" e individuales - y con ellos a toda la institución policial que representan — hasta el propio sistema judicial. Así, los dos primeros capítulos se dedican a demostrar la culpabilidad de Fernández Suárez, jefe de policía de la provincia de Buenos Aires y quien dio la orden de fusilamiento; el tercero, "El expediente Livraga", será una demostración a partir de la "historia oficial del caso"; en el último capítulo, la impugnación se hará sobre el fallo de la "Suprema Corte de Justicia de la Nación". "La evidencia" es volver a contar lo contado, ensayando otros recursos; es rehacer el relato para ensayar otra forma de aproximación a la barbarie.

Así, "La evidencia” es un 'capítulo' más en la búsqueda por encontrar una forma de relatar la atrocidad del fusilamiento; el narrador, al comparar la Argentina de la Revolución Libertadora con la Alemania nazi, ya en 1964, percibe que por detrás de esa matanza hay algo más que actos individuales, aunque todavía le sobre un resto de creencia en la justicia.

\section{La institución policial}

"Los fantasmas", capítulo que abre "La evidencia", relata las medidas que Fernández Suárez va tomando desde la madrugada del fusilamiento, el 10 de junio de 1956, hasta el 18 de diciembre del mismo año, cuando ya ha sido denunciado en varias instancias y las acusaciones han llegado a la Junta Consultiva ${ }^{134}$. "Los fantasmas" son los que amenazan la impunidad de Fernández Suárez: sobre este recae no solo la acusación del fusilamiento clandestino, sino también la de ser responsable o tolerante con el sistema de torturas y malos tratos dentro de las cárceles de la provincia de Buenos Aires.

La demostración de la culpabilidad de las instituciones del Estado se va construyendo a partir de los involucrados "menores", de los que aparentemente "cumplen órdenes", en una especie de contrapunto que va cercando cualquier posibilidad de "malabarismos capaces de borrar la terrible evidencia de que el gobierno de la Revolución Libertadora" fue el mentor de los asesinatos.

\footnotetext{
${ }^{134}$ Organismo que agrupaba representantes de diferentes partidos políticos, creado por decreto por el gobierno de la Revolución Libertadora.
} 
Así, "La evidencia" comienza con las perplejidades de Rodríguez Moreno, el ejecutor de la orden de fusilamiento, contrapuestas al estado de alerta de Fernández Suárez:

Rodríguez Moreno era un hombre agotado y perplejo cuando a las seis de la mañana del 10 de junio informó por radio a la Jefatura de La Plata que la orden de fusilamiento estaba cumplida. ¿Mencionaría la fuga de más de la mitad de los prisioneros? Optó por callarse.

Jefatura no dormía. Pidió la nómina de los fusilados. Y ahora sí, Rodríguez Moreno no tuvo más remedio que enviar la lista de los cinco muertos.

— ¿Y los otros? —vociferó Fernández Suárez. (p. 179)

Observemos los contrastes entre un hombre cansado y estupefacto y otro que vocifera, contraste que se reproduce en la sintaxis que describe a cada uno. En la primera oración, sin ninguna puntuación, se reproduce la lentitud del agotamiento (para poder enunciarla sin parar para respirar, hay que hacerlo lentamente). Contra el cansancio de uno, el estado de alerta del otro, reflejado en la oración corta, seca; la duda en relación a Rodríguez Moreno, “¿Mencionaría la fuga...?”, frente a la afirmación para Fernández Suárez, "Jefatura no dormía". El contrapunto también se plantea entre personaje y narrador. En la pregunta, “¿Mencionaría...?”, la duda puede ser del narrador pero también de Rodríguez Moreno: el condicional, de primera o tercera persona, crea la posibilidad de ambos puntos de vista; pero entonces llega la afirmación, también seca, "Optó...".

Esa especie de "tira y afloja" se refuerza en la elección de la oración de sentido figurado y familiar - "no tuvo más remedio"- que se lee a continuación; o en los adjetivos "agotado", "perplejo": ¿agotado por la situación? ¿o por la hora?; ¿perplejo por la orden que tuvo que cumplir? ¿o porque se le habían escapado más de la mitad de los prisioneros?

Estas formas posibles de "leer" a Rodríguez Moreno no se presentan en relación a Fernández Suárez: él es la "Jefatura" que no duerme, él es la Institución alerta, que sabe que violó la ley, que cometió un crimen:

...el jefe de Policía [...] ha detenido a una docena de hombres antes de entrar en vigor la Ley Marcial. Los ha hecho fusilar sin juicio. Y ahora resulta que siete de esos hombres están vivos. (p. 180) 
A partir del enunciado del problema, comienza un recuento de las medidas que toma Fernández Suárez para protegerse de las consecuencias de sus actos: dispersa a los "ejecutores materiales y testigos" del crimen y frente a la sospecha de que los fusilamientos fueron una coartada porque "jugaba a dos puntas" ${ }^{135}$, llama a conferencia de prensa y se explica. "Parece que va a dormir tranquilo Fernández Suárez." (p. 181), pero llega la denuncia del doctor Doglia.

Hay algo de implacable ${ }^{136}$ en la forma de presentar los hechos - aunque aquí, esa forma, apenas se insinúa, irá creciendo capítulo a capítulo y acabará predominando en toda la tercera parte-: el narrador arrincona al jefe de policía, lo cerca, lo denuncia, revela sus actos, interpreta cada movimiento o palabra del mismo, como si librase una batalla:

Las medidas que adopta [Fernández Suárez] revelan que comprende su situación. Lo primero es dispersar a los ejecutores materiales y testigos [...]

El 12 de junio los diarios publican una lista [...] de cinco "fusilados en la zona de San Martín" [...] La noticia no dice quién los detuvo, quién ordenó matarlos y por qué, no alude siquiera a la fuga de los otros siete. Interesante precaución.

Pero Fernández Suárez se ve obligado a hablar [...] Él reúne a los periodistas y les explica, según los diarios platenses del 11 y 12 de junio... (p. 180)

Aquí, la sintaxis expositiva, sin adjetivación, presenta los hechos con lenguaje preciso y los actualiza con el presente y el perfecto (recordemos que este capítulo Walsh lo escribe para la segunda edición). El único comentario, encabezado por "Interesante", en su aparente neutralidad y sequedad, se carga de ironía al estar colocado a continuación de la enumeración de lo que Fernández Suárez no hizo.

Y siguiendo en el terreno de la ironía, cuando Fernández Suárez se entera de que el Dr. Jorge Doglia, jefe de la División Judicial de la Policía, lo ha denunciado por apremios ilegales, el narrador relata la siguiente situación:

\footnotetext{
135 "Algunos insinuarán que el jefe de Policía jugó a dos puntas esa noche y que los fusilamientos que luego ordenó fueron su coartada." (p. 180).

${ }^{136}$ Esta sensación se ve confirmada en el "Epílogo” de 1964; allí se lee: “...lo perseguí [a Fernández Suárez] con la misma ferocidad con que él persiguió, torturó, mató; lo flagelé semana a semana.” (p. 297).
} 
—Único caso en mi Jefatura — dirá luego, hondamente arrepentido, Fernandez Suarez $[\mathrm{sic}]^{137}$ — en que un señor de la calle pasa a inspector mayor.

Eso es cierto. Para la policía, Doglia es un "señor de la calle", lo mismo que Fernández Suárez, que lo ha nombrado. (p. 181-182)

En la réplica a las palabras de Fernández Suárez hay, primero, una afirmación sin ornamentos, y después la afirmación irónica: sabemos que el jefe de policía debería ser tan "de la calle", en relación a sus deberes y obligaciones, como Doglia; pero no lo es. Además, con la ironía se recuerda que la policía debería estar al servicio de la población.

Y como el arma privilegiada del escritor es la palabra, será en ese terreno, en el de las declaraciones de los culpables, que se dará la batalla. Será allí que predominará la ironía y la burla, único recurso que parece haber restado frente a la impunidad oficial. Así, a lo largo de estos capítulos se reproducirán trechos de declaraciones a la prensa y a los jueces, que el narrador irá discutiendo, a veces párrafo por párrafo, otras, oración por oración y hasta palabra por palabra; siempre "persiguiendo" y "flagelando".

Fernández Suárez, al saberse sospechoso de haber jugado a dos puntas, llama a conferencia de prensa; el narrador transforma dicha conferencia en la primera prueba "oficial" que invoca como demostración de la culpabilidad del jefe de policía. Y hace más: al transcribir toda la declaración de Fernández Suárez sobre sus movimientos el día de los fusilamientos, reproduce la propia forma de Operación masacre: agrega detalles —otro relato de los hechos - y puntos de vista, esta vez el del jefe:

En esa resistencia medió una circunstancia afortunada, como es el hecho de que me encontrara fuera del Departamento. En la emergencia había viajado hasta la localidad de Moreno, donde la explosión accidental de una bomba permitió descubrir en una quinta perteneciente al ingeniero Sarrabayouse, de filiación peronista, un arsenal en el que secuestramos 31 bombas de tiempo, de gran poder. Me hallaba en ese procedimiento, el día sábado, cuando me enteré de que en una casa de departamentos de Vicente López se había realizado una reunión clandestina, entre los que se sindicaba al general Tanco. El procedimiento permitió detener a catorce personas, pero el citado militar no fue

\footnotetext{
${ }^{137}$ En la edición que manejo, "Edición Definitiva”, el apellido aparece sin los acentos. En todas las otras, inclusive la última, en este pasaje, solo aparecían las iniciales "F.S".
} 
capturado. SIENDO LAS 23 HORAS Y HALLÁNDOME EN ESTA CASA, me enteré de la sublevación en la Escuela de Mecánica y en Santa Rosa. (p. 180181)

Sobre estas palabras, el narrador llamará la atención; primero, acerca de lo que no dicen ("Ni una palabra sobre el destino ulterior de esas personas." (p. 181)) y, a continuación, retomará lo que ya está destacado en la propia transcripción:

...Fernández Suárez ya se está traicionando. Porque lo fundamental que dice aquí cuando nadie todavía lo acusa, es que detuvo a esas personas a las 23 horas. Una hora y media antes de promulgarse la Ley Marcial. (p. 181)

La cursiva es del propio narrador. Aquí, hay una especie de doble ironía: una contenida en la idea de autoacusación; la otra, en la forma didáctica, que informa y destaca, a modo de conclusión, algo que es obvio; que repite lo que ya había sido destacado con mayúsculas en el trecho citado; que calcula lo que el lector podría calcular por sí mismo.

Aunque el título evoca al fantasma de Hamlet (lo sabemos del capítulo anterior) y, con él, toda la tradición de la tragedia, que habla de una comunidad que retorna a la armonía perdida excluyendo de su seno al héroe trágico que la llevó al descalabro, lo que sucede aquí es exactamente lo contrario. O sea, estamos nuevamente frente a la doble ironía: el título es irónico en relación al personaje y en relación a la propia tragedia.

La ironía y el "acoso", que empiezan a esbozarse "tímidamente" en este primer capítulo, van creciendo hasta transformarse, frente a la indiferencia oficial, en una burla explícita, sin disimulo; y lo hacen hasta el cansancio, repitiendo una y otra vez la misma historia. Así, en el capítulo siguiente, "Fernández Suárez confiesa", el sarcasmo gana espacio ya desde el título; una "confesión" es en lo que el narrador transforma las declaraciones del jefe de policía a la Junta Consultiva; se apropia de las palabras de Fernández Suárez y muestra no solo su culpabilidad, sino también, una vez más, la veracidad de los hechos que ha narrado. La forma del capítulo es la de la refutación, pero también la de la repetición.

Las declaraciones del policía son presentadas de dos maneras diferentes. En la primera, el narrador nos pide a los lectores que dejemos de creerle a él y que confiemos en las 
palabras de Fernández Suárez: "Aquí quiero pedir al lector que descrea de lo que yo he narrado [...] y crea solamente en aquello que [...] dijo Fernández Suárez" (p. 186). Luego, va pautando la lectura: transcribe y comenta trechos sueltos, pero siguiendo el orden de las declaraciones del jefe de policía: desde la existencia misma de los detenidos hasta el hecho de que no se resistieron. Cito a continuación un solo ejemplo, pues el recurso será el mismo para cada pasaje:

Y cuando digo que esos hombres no intervinieron en el motín del 9 de junio de 1956, extreme el lector sus dudas. Pero dé crédito a Fernández Suárez cuando declara:

“...ESTA GENTE... ESTABA POR PARTICIPAR EN ESTOS ACTOS...”

Estaba. Es decir, no había participado. (p. 187)

Otra vez tenemos la misma información y añadida la explicación "didáctica", resaltada en cursiva.

La otra forma de presentar las declaraciones de Fernández Suárez es transcribiendo íntegramente la versión taquigráfica de la defensa que el jefe de policía hace de sí mismo. La justificación que el narrador da para usar ese recurso es que no quiere que se lo acuse de manipular la información; puede ser que sea ese el motivo, pero no se puede dejar de apuntar que ese volver sobre lo mismo, pero con otra forma, en realidad repite nuevamente, en la breve secuencia, la propia estructura de Operación masacre.

El capítulo cierra con una síntesis de lo que fue probado:

Lo importante es que en base a la propia confesión de Fernández Suárez queda DEFINITIVAMENTE APROBADO:

1. Que el 9 de junio de 1956 detuvo a un grupo de hombres entre los que estaba Livraga.

2. Que la detención de esos hombres se produjo a las 23 horas del 9 de junio, es decir una hora y media antes de promulgarse la Ley Marcial.

3. Que esos hombres no habían participado en el motín.

4. Que esos hombres no opusieron ninguna clase de resistencia al arresto. 
5. Que a la madrugada esos hombres fueron fusilados, "por orden del Poder Ejecutivo", según Fernández Suárez. (p. 189)

En definitiva, en este capítulo, se reconstruyen exhaustivamente hechos puntuales ya narrados y se los discute didácticamente como otra estrategia de persuasión.

\section{La institución judicial}

"El expediente Livraga" es una síntesis y un comentario del documento oficial del caso, producto de la investigación judicial. Es incorporado en Operación masacre a partir de la segunda edición (1964), como prueba de todo lo relatado. Partiendo de dicho documento, leemos en este capítulo un sumario de la denuncia de Livraga y del relato de Giunta; se describen las providencias tomadas por el juez que entendía en la causa; se transcriben respuestas a exhortos y declaraciones de los implicados en el fusilamiento. Para la presentación de todo este material, que como el autor dice es la "historia oficial del caso", sigue el orden de las "fojas" ${ }^{38}$; se recrean diálogos, se transcriben las versiones taquigráficas e información periodística (p. 210). Es como estar leyendo otra versión de Operación masacre, con otra forma; desde otro ángulo.

La descripción del expediente se va haciendo en el orden cronológico de la investigación del juez y siguiendo el número creciente de las fojas. Del relato de Livraga, el narrador cita solo lo que le quitaron en la comisaría (p. 193); no así de lo que narra Giunta, de quien transcribe su descripción del momento del fusilamiento (p. 198). A continuación cita las declaraciones de Jorge $R$. Dillon, interventor en la obra social de la policía, que es uno de los testigos que oyó cuando Fernández Suárez daba la orden de fusilamiento (p. 198199). Algunas páginas más adelante, transcribe largamente la confesión del inspector Rodríguez Moreno (p. 202-208) y parte de la del comisario Cuello (p. 211-215). El capítulo termina con una carta de respuesta enviada al juez Hueyo por Fernández Suárez y el reclamo de la causa por la justicia militar y las respectivas respuestas del juez (p. 216223). Todo esto intercalado, al igual que en capítulo anterior, por las intervenciones del narrador.

\footnotetext{
${ }^{138}$ Hoja de papel, sobre todo de un documento oficial. (DRAE)
} 
Antes de comenzar la descripción del expediente, el narrador hace una introducción en la cual repasa las versiones oficiales sobre los hechos, demostrando que "fueron sistemáticamente negados, o desfigurados, por el gobierno de la Revolución Libertadora". (p. 191) Y digo "repasa" porque no hay ningún dato nuevo, no hay nada que no haya sido contado y comentado anteriormente. En sus comentarios, el narrador mantiene el tono irónico y burlón, reforzado por explicaciones de aspectos obvios:

Ese mismo sumario ${ }^{139}$ admite después que Livraga "presentaba lesiones", pero las toma como "evidencia de su activa participación en el movimiento revolucionario".

Era una bonita manera de invertir la prueba. Las heridas de Livraga no probaban que hubiera sido fusilado, sino que era un revolucionario... (p. 191192) [la cursiva es mía]

Además de que el segundo párrafo comenta y explica el primero, ahora la ironía y ridiculización es explícita y de uso absolutamente corriente ("bonita"). Se podría decir que, a esta altura de la lectura, en el "pero" del primer párrafo ya sabemos lo que el narrador piensa, sin embargo, éste lo afirmar por repetición, lo deja escrito y explícito. La ridiculización se acentúa por la retomada de las palabras del documento y el fin del párrafo con puntos suspensivos, sin ningún comentario.

Y por el silencio también opta el narrador en relación a la institución judicial. Después de una única alusión a los jueces "facciosos, ineptos o simplemente corrompidos", elige referirse a la excepción:

Mi experiencia personal con los jueces, en cuanto periodista, no ha sido alentadora. Podría nombrar a una docena, a quienes conozco como individuos facciosos, ineptos o simplemente corrompidos. Prefiero señalar como ejemplo de decisión, rapidez y eficacia la actuación que tuvo en este caso el juez Hueyo. (p. 193)

En el contrapunto entre decir y callar está la refutación de todo un sistema que subvierte el valor de la justicia, que desprecia la vida. Y este también es el caso del comisario

\footnotetext{
${ }^{139}$ El sumario al que se refiere es el que el Ministerio de Gobierno de la Provincia le hace al Dr. Doglia. Como fue comentado, Doglia había presentado una denuncia, contra Fernández Suárez, que constaba de dos partes: "una se refiere al sistema de torturas; otra al fusilamiento ilegal de Livraga" (p. 182).
} 
Cuello. Ante este personaje, la estrategia del narrador es llamarse al silencio para lo que no hay palabras o simplemente ridiculizar lo obvio:

"...al establecerse cuántas eran las personas fusiladas, advirtieron que eran sólo cinco en vez de doce o trece que se conducía, y en ese momento advirtieron que algunos de los presos se habían dado a la fuga".

— ¿Cuándo fue eso? —pregunta el juez.

Cuello lo ignora. Él concurrió solamente "como testigo y como apoyo moral (sic) para el jefe, que había asumido la dirección de la ejecución”.

Parece obvio que cuando uno está empeñado en una tarea moral de ese calibre no puede reparar en detalles. Pero la fuga, aclara Cuello, "ha sido antes del fusilamiento". (p. 213)

Además del sarcasmo contenido en el "sic" y el "Parece obvio...", la última oración que cita las palabras de Cuello, si no fuese tan grave lo que estamos tratando, movería a la risa; dada la gravedad, hasta el juez tiene que intervenir con otra pregunta " ¿Es posible que algunos de los que estaban frente al pelotón resultaran ilesos?" (p. 213), que aunque tampoco es del todo clara y refuerza el desbarajuste general, por lo menos intenta alguna precisión.

El sarcasmo sin disimulos sobre las declaraciones de Cuello es provocado por la propia actitud del comisario frente a los hechos:

Es un tejido de imprecisiones y evasivas el testimonio de este policía que, a diferencia de Rodríguez Moreno, cree que los muertos están bien muertos y que no hay que andar averiguando tanto. (p.215)

Siguiendo en la línea del "silencio", de lo no comentado, es lo que se "lee" en relación a los diálogos entre el juez Hueyo y los comisarios Ferrairone, Gregorio de Paula -ambos de la comisaría de Moreno- y Cuello; a veces indicados con las marcas de diálogo y otras no, ponen de relieve las mentiras de los policías y el cinismo de los comisarios:

¿Estuvo bien atendido Livraga? Espléndidamente, dice el comisario. Hasta le daban "alimentos que no requerían ser masticados". 
¿Pasó frío Livraga? No, dice el comisario, "en sus recuerdos se le aparece envuelto con algo de abrigo, pero no puede precisar qué ropa era".

— ¿Le tomaron declaración?

No.

— ¿Le hicieron sumario?

No.

— ¿Fue alguien a visitarlo?

No. (p. 202)

Después de esta transcripción, hay un espacio en blanco y comienza la parte dedicada a Rodríguez Moreno; es decir, el "silencio" es más que elocuente.

En relación a la repercusión del caso en los medios periodísticos, el narrador transcribe trechos de noticias aparecidas en dos periódicos: El Argentino, de La Plata, y La Razón, de Buenos Aires. En ambos se hace referencia a una reunión a la que asistió Fernández Suárez con el interventor de la provincia, Bonnecarrere; ninguno de los dos menciona el expediente Livraga, solo informan sobre la reunión en la "que se habían discutido 'acontecimientos producidos el año pasado en la zona de San Martín'." (p. 211). El narrador se "limita" a comentar: "En estos eufemismos se agotó la libertad de prensa de que gozaba el país.", pero refuerza: "La opinión pública nunca fue informada de la existencia del expediente Livraga." (p. 211).

El capítulo termina con un análisis "irrefutable" del doctor Hueyo sobre "el punto crucial de su investigación: la hora a la que se promulgó la ley [marcial]" (p. 222).

\section{La justicia}

La salida de Fernández Suárez para mantener su impunidad es que el caso pase de la justicia civil a la militar; y es lo que acaba sucediendo, con todo el gobierno de la Revolución Libertadora como respaldo. "La justicia ciega" será una demostración de la arbitrariedad de las decisiones judiciales, con los mismos recursos usados en los capítulos anteriores - transcripción de dictámenes y fallos, comentados por el narrador-, pero ahora el tono es el de la impotencia y la indignación. El narrador vuelve sobre la historia y la ilegalidad del fusilamiento para formular su propia sentencia y concluir que se trató de un asesinato. 
Al comienzo del capítulo se lee la transcripción del dictamen y el fallo del juez de la Suprema Corte de Justicia. El narrador, en su comentario introductorio, no ahorra epítetos: "uno de los fallos más oprobiosos", "una titulada justicia militar, ...cómplice y facciosa" (p. 225), "pueril vaguedad...", "cosa [...] falsa..." (p. 226) $Y$ ahora el ridiculizado es el juez de la Suprema Corte:

...la denuncia de Livraga, que es la que se plantea, se refiere a un delito cometido el 10 de junio, que es lo mismo que decir un día después, un año después, un siglo después. ¿O es que un célebre jurista llega a creerse un ángel o un personaje de Wells, para jugar así con el tiempo? En media carilla, el doctor Soler se traga todo lo que durante décadas ha enseñado en sus cátedras y en sus textos. (p. 226)

Después de transcribir el veredicto de la justicia, el narrador también emite su sentencia - "el dictamen del procurador y el fallo de la Corte eran una siniestra corrupción a la norma jurídica" (p. 227) - y hace un resumen "en la forma más llana" de argumentos que lo justifican. La indignación frente a la decisión judicial es tanta, es tan obvia la violación de la ley por los propios representantes de la misma y su cínica impunidad, que el narrador recurre a la repetición y al didactismo para mostrar una vez más lo absurdo de la resolución.

\begin{abstract}
Mientras está detenido, Livraga naturalmente no comete delito alguno. Ese día termina - como todos - a las doce de la noche. Al día siguiente (no importa que hayan pasado apenas 32 minutos, ya es el día siguiente, el 10 de junio), se promulga una ley, que es la Ley Marcial. Esa ley empieza a regir el 10 de junio. Livraga, preso desde el día anterior, no la puede violar. Es como si esa ley no existiera para Livraga, ni Livraga para esa ley; son esferas que no se tocan; cualquier cosa que se le haga en nombre de esa ley, cualquier pena que se le inflija, será un delito. (p. 228)
\end{abstract}

Y así continúa el párrafo explicando y repitiendo que Livraga está fuera del alcance de la Ley Marcial. Al detenerse en detalles obvios, el narrador llama la atención del lector a través de la ridiculización de la capacidad de entendimiento de la Corte y del propio fallo. Hasta el título del capítulo, "La justicia ciega", es una alusión irónica a la propia institución judicial. En ese mismo tono sigue casi hasta el final, cuando concluye: 
Que los detenidos de Florida fueron penados, y con la muerte, y sin juicio, y arrancándoles a los jueces designados por la ley antes del hecho de la causa, y en virtud de una ley posterior al hecho de la causa, y hasta sin hecho y sin causa.

No habrá ya malabarismos capaces de borrar la terrible evidencia de que el gobierno de la Revolución Libertadora aplicó retroactivamente, a hombres detenidos el 9 de junio, una Ley Marcial promulgada el 10 de junio.

Y eso no es fusilamiento. Es un asesinato. (230)

Así, "La evidencia" es un recontar de los sucesos del 9 de junio para demostrar que se trató de un crimen cometido por el Estado contra sus ciudadanos. Para eso el narrador no solo refuta el discurso oficial sino que también lo registra, registra la "narración" hecha desde las propias instituciones, incorporando así otro punto de vista, otra voz. Este movimiento además permite que el lector, por comparación, saque sus propias conclusiones. Podemos hablar de una "didáctica de la persuasión".

\subsection{CÓMO INTERPRETAR: Epílogos}

Aunque Operación masacre está marcada por un contar y recontar — desde diferentes ángulos y voces - la historia de los sucesos de junio de 1956, los epílogos fueron el lugar privilegiado de ese rehacer incesante, al ritmo de la historia del país, en busca del sentido de aquel "amenazante mundo exterior" con el que de repente se deparó el narrador. Si en el epílogo de 1957 los hechos históricos se narran desde la memoria, desde lo subjetivo e individual, en 1972, el relato se apoya en formas de objetivar los hechos y la historia es entendida como colectiva, como la historia de todos.

En la edición definitiva de Operación masacre hay, a continuación de "La justicia ciega", un "Epílogo" y a seguir un capítulo más, el 37: "Aramburu y el juicio histórico". El "Epílogo" corresponde a la primera parte del escrito para la tercera edición (1969), que también consta en la última (1972); el capítulo 37 corresponde a esta última publicación y sustituye la secuencia final del epílogo del '69. 
Aquí comentaré cada uno de los epílogos y el capítulo 37. La opción por pensarlos juntos, como parte de una secuencia, se debe a que es en estos capítulos de Operación masacre donde mejor se acompaña el recorrido que puede indicar la convergencia entre las instancias del narrador, del autor, del ciudadano: la definición política, la toma de posición, la opción por dejar lo individual y sumergirse en lo colectivo se reflejan en la escritura de los epílogos ${ }^{140}$.

\section{"La paz no es aceptable a cualquier precio": "Provisorio epílogo" (1957)}

En el "Provisorio epílogo" se lee una argumentación contra las revoluciones de cualquier tipo y a favor de la paz:

Si hay algo justamente que he procurado suscitar en estas páginas es el horror a las revoluciones, cuyas primeras víctimas son siempre personas inocentes... (p. 293)

Pero también, como veremos, está el "germen" del último capítulo que Walsh escribirá, en 1972, para Operación masacre: "Aramburu y el juicio histórico".

La argumentación está construida a partir del recuerdo de algunas experiencias personales del autor-narrador durante las últimas revoluciones ${ }^{141}$. Recuerda, "sin remordimiento", su apoyo a la Revolución Libertadora, en 1955, que creyó como muchos que llegaría para ponerle fin a "un sistema que burlaba las libertades civiles" (p. 289). Un tiempo antes, en junio, había habido un intento de golpe contra el gobierno del general Perón; en esa oportunidad, Walsh escribe un artículo elogioso en homenaje a tres aviadores $^{142}$, uno de ellos peronista, muertos durante la intentona; aunque censurado, por el ministerio de Marina, el autor decide asumir la publicación. El motivo de la censura era exactamente el elogio al aviador peronista.

\footnotetext{
${ }^{140}$ Para mayor claridad, a continuación me refiero a cada uno de los epílogos colocando la fecha de la edición a la que corresponden y el número de página de la Edición definitiva.

${ }^{141}$ En 1957, el narrador homologa bajo el mismo rótulo hechos históricos de diferente sentido. Recordemos que se trata de las "revoluciones" de junio de 1955 -intento fallido de golpe contra el general Perón, derrocado por los partidarios del gobierno, y en el cual las FFAA bombardearon a la población civil en Plaza de Mayo -; la de setiembre de 1955 —golpe de Estado, también contra Perón, esta vez triunfante-y la de junio de 1956 - levantamiento cívico-militar contra el gobierno golpista de 1955, con el fin de restaurar al peronismo depuesto del gobierno constitucional—. Ver capítulo 1 de este trabajo.

142 "2-0-12 no vuelve" apareció en Leoplán el 21 de diciembre de 1955. Se puede leer el artículo en la recopilación de la obra periodística de Rodolfo Walsh hecha por Daniel Link, El violento oficio de escribir (WALSH, 1998, pp. 21-29).
} 
El otro recuerdo decisivo del narrador es la muerte de un conscripto en la puerta de su casa, durante la revolución de 1956 (la que dio lugar a Operación masacre). Antes de esa rememoración, evoca instantes de la noche del 9 de junio en la que, alternativamente, entra en contacto con integrantes de ambos bandos — primero para llegar a su casa, con uno de los revolucionarios peronistas; una vez dentro, con los que defienden al gobierno-.

El impacto que estas experiencias dejan en el autor-narrador, sin duda, es el que dicta el deseo de suscitar "el horror a las revoluciones". La construcción del relato de cada uno de estos episodios está hecha con tal idea:

...Esos restos carbonizados e irreconocibles de tres hombres [los aviadores], dos revolucionarios y un peronista, dentro de un mismo avión hecho pedazos, caídos en una misma lucha, consumidos en idéntico fuego de heroísmo, significaban algo indudablemente. Eso era un signo, eso era una advertencia, eso era un símbolo tremendo, eso era una pacto sellado con sangre. ¿Qué decir ahora, a casi dos años cuando los miopes, los cobardes y los torpes no han hecho más que violar semejante compromiso? Sólo se me ocurre decir: afortunados aquellos tres, que están muertos, unidos e intocados en su gloriosa eternidad. (p. 290)

La descripción de los cuerpos en el avión; la descripción de los motivos que llevaron a la unión de esos cuerpos; la acumulación de significados y la conclusión —un elogio de la muerte heroica - no pueden producir, en el lector, otra sensación que la de espanto. El mismo dolor provoca la descripción de la muerte del conscripto: ...Escuché el grito de terror y soledad que lanzó al caer, cuando la patrulla
tomada de sorpresa se replegó momentáneamente: “No me dejen solo! ¡Hijos
de p..., no me dejen solo!” [...] Bernardino Rodríguez, de 21 años, murió
creyendo que sus camaradas, sus amigos, lo abandonaban en la muerte. Y eso
me dolió entonces, y me sigue doliendo ahora, como tantas cosas inútiles. (p.
292)

Con el espanto, el dolor y la declaración explícita del narrador de sus intenciones llegamos casi al fin del epílogo, donde leemos, en una oración sola que constituye un párrafo, y que parece una conclusión: "Solo un débil mental puede no desear la paz." ( $p$. 293). Pero inmediatamente, en otra oración sola, se lee: 
Pero la paz no es aceptable a cualquier precio. (p. 293)

Así, ambas afirmaciones se destacan como conclusión. Es como si el narrador nos hubiese hecho acompañarlo por ese recorrido "intimista" de la memoria con la idea del horror a las revoluciones, para cerrar el capítulo con un párrafo contundente sobre el origen de lo que él hasta ese momento considera la violencia equivalente de ambos lados:

Y siempre habrá en germen nuevos levantamientos, y nuevas olas de insensata revancha - aunque luego tengan sentido contrario-, mientras se mantengan al frente de los organismos represivos del Estado hombres como el actual Jefe de Policía de la Provincia de Buenos Aires, teniente coronel Desiderio Fernández Suárez. (p. 293)

La conciencia contenida en esta última afirmación es el "germen" de lo que luego será "Aramburu y el juicio histórico". Pero, todavía faltan algunos años para la escritura del capítulo 37. Por eso, en el epílogo de 1964 (p. 295) solo encontraremos un relato hecho a partir de lo personal. Se anuncia como un balance de ganancias y pérdidas:

Ahora quiero decir lo que he conseguido con este libro, pero principalmente lo que no he conseguido. Quiero nombrar lo que de alguna manera fue una victoria, y lo que fue una derrota; lo que he ganado y lo que he perdido. (p. 295)

Si en el texto de 1957, para hacer el balance, las referencias eran sobre sucesos "externos" a Operación masacre, ahora todo girará alrededor de los hechos investigados y narrados en el libro que estamos leyendo. Como veremos, el balance de logros y pérdidas conduce al autor-narrador a otras indagaciones: sobre su práctica como periodista, sobre su práctica como lector y escritor.

Las ganancias ocupan un solo párrafo: aclaró hechos inverosímiles casi con la única ayuda de "una muchacha y unos pocos hombres acosados que eran las víctimas"; se sobrepuso al miedo, al propio y al de las víctimas; consiguió que los involucrados hablasen; y también, después de algunos años, se reencontró con Troxler — -con la sonrisa infantil de Troxler" (p. 296) — y no hablaron del fusilamiento. 
Las pérdidas fueron muchas. Primero, las sociales e históricas: ningún gobierno —ni el de Aramburu, ni el de Frondizi, ni el de Guido - reconoció que la noche del 9 de junio "se cometió una atrocidad" ${ }^{143}$ y no hubo ningún tipo de reparación para las víctimas, ni moral ni material. Al contrario, los victimarios fueron ascendidos. Para enunciar los fracasos, el narrador se refiere a lo que esperaba obtener a partir de la investigación y la denuncia de los fusilamientos:

Pretendía que, a esos hombres que murieron, cualquier gobierno de este país les reconociera que la justicia de este país los mató por error, por estupidez, por ceguera, por lo que sea. Yo sé que a ellos no les importa. Pero había una cuestión de decencia, no sé cómo decirlo. (p. 296)

Error, estupidez, ceguera... Aunque estamos en 1964 y Walsh ya ha investigado el caso Satanowsky y ha participado en la Revolución cubana; y Operación masacre ya incorpora el "Expediente Livraga", el narrador todavía parece considerar una posibilidad de que el crimen haya sido cometido por error, todavía se resiste a creer que sea posible la impunidad; pero comienza a manifestar el cansancio; ya admite que no le alcanzan las palabras - "no sé cómo decirlo."-, la indignación todavía no se manifiesta como acción militante. Y la lista de pérdidas crece y el cansancio también: "Aramburu ascendió a Fernández Suárez; no rehabilitó a sus víctimas. Frondizi [...] ascendió a Aramburu. Creo que después ya no me interesó." (p. 297) [la cursiva es mía].

También hay dos retractaciones: una en relación a una frase escrita en la primera edición de Operación masacre: "Este caso está en pie, y seguirá en pie todo el tiempo que sea necesario, meses o años"; la otra, se refiere a la campaña "encarnizada" contra Fernández Suárez, al constatar que no era ni iba a ser castigado por la justicia:

\footnotetext{
${ }^{143}$ En la introducción a una entrevista (sin firma) a Fernández Suárez, hecha por el periódico Primera Plana en 1965, podemos tener una dimensión de la impunidad de la que siguió gozando, a lo largo de los años, el jefe de policía: "El miércoles último [...] se divulgaron dos cartas enviadas por Fernández Suárez, el 20 de noviembre de 1964, al presidente de la Cámara de Diputados, Arturo Mor Roig, y al secretario de Guerra, general Ignacio Ávalos. En ellas rechaza los cargos formulados por Cornejo Linares [diputado justicialista] y por 'libelos y prensa sensacionalista' y declara que 'los civiles (fusilados) estaban en la intentona revolucionaria', que él no ordenó las ejecuciones y que la Justicia militar ya se había pronunciado sobre el tema." En la misma entrevista se comenta que, en mayo de 1964, "el diputado justicialista Juan Carlos Cornejo Linares presentó un proyecto tendiente a conceder pensiones a los familiares de los fusilados y acusó otra vez a Fernández Suárez." Esta entrevista se puede leer en Rodolfo Walsh, vivo, recopilación de textos de y sobre Rodolfo Walsh hecha por Roberto Baschetti, (BASCHETTI, 1994, p. 130)
} 
...lo perseguí quizá con la misma ferocidad con que él persiguió, torturó, mató; lo flagelé semana a semana. En la medida que esa tentativa me haya hecho parecido a él, pido nuevamente retractarme. (p. 297)

Aunque irónica, con esta retractación el narrador hace y le recuerda al lector lo que las Instituciones nunca hicieron: manifestarse, asumir sus actos.

Después vienen las pérdidas personales: la de "algunas ilusiones, la ilusión en la justicia, en la reparación, en la democracia, en todas esas palabras" (p. 298) y finalmente la desilusión en relación al propio oficio de periodista. Y esta forma parte del mismo tipo de indagación: después de Operación masacre, Walsh investigó el caso Satanowky —crimen en el que probó que estaban involucrados los servicios de información del Estado y los medios periodísticos ${ }^{144}$ - y los fracasos se repitieron: "Ios muertos bien muertos, y los asesinos probados, pero sueltos." (p. 297):

Entonces me pregunté si valía la pena, si lo que yo perseguía no era una quimera, si la sociedad en que uno vive necesita realmente enterarse de cosas como éstas. (p. 298) [la cursiva es mía]

Obsérvese la ambigüedad de este pasaje. Al usar el verbo "necesitar" — en lugar de "querer", por ejemplo - deja realmente las necesidades de la sociedad en el plano de la duda y no en el de la voluntad, pero la voluntad puede ser individual y puede excluir el nivel de la conciencia. Y el narrador sabe de eso; no en vano plantea su "duda" después de recordar los varios casos de impunidad de las instituciones.

Si nos dejamos seducir por "el sonido de las palabras" podemos creer que, en lo que se refiere a las pérdidas, realmente el epílogo trata más de derrotas que de victorias. Los dos últimos párrafos, después de la enumeración de las desilusiones, pueden darnos alguna pista en otro sentido:

\footnotetext{
${ }^{144}$ Recordemos que se trata de la investigación periodística sobre el asesinato del Dr. Marcos Satanowsky, conocido abogado que defendía los intereses de uno de los accionistas del diario La Razón. Walsh probó que estuvieron involucrados en el crimen la SIDE (Secretaría de Inteligencia del Estado) y los grandes medios de información fueron cómplices. Los artículos aparecieron en Mayoría entre junio y diciembre de 1958.
} 
Releo la historia que ustedes han leído. Hay frases enteras que me molestan, pienso con fastidio que ahora la escribiría mejor.

¿La escribiría? (p. 298)

Se puede pensar que este final viene como remate del desánimo anunciado; podría entenderse como una forma de "cambiar de asunto", de no referirse ni a la desilusión ni a la muerte; pero el asunto sigue siendo el mismo: resistir por la escritura; y por eso, escribirá y continuará escribiendo más epílogos ${ }^{145}$.

\section{“Dentro del sistema, no hay justicia”: "EPÍLOGO” (1969)}

El epílogo escrito para la tercera edición es el que consta en la definitiva (pp. 231-233), pero aquel incluía una secuencia final, "Retrato de la oligarquía dominante" (pp. 299-300), que a partir de la cuarta edición es substituido por el capítulo 37, "Aramburu y el juicio histórico" (p. 235). Nuevamente, para mayor claridad comento cada una de estas partes como aparecieron en sus respectivas ediciones.

Ahora, en 1969, el autor-narrador prácticamente ha dejado lo personal y ha pasado a la historia social y política: los fusilamientos en el basural y las ejecuciones de los militares en los cuarteles después del alzamiento de 1956 forman parte de un mismo sistema; los fusilamientos, las torturas y asesinatos que los precedieron y sucedieron no son hechos anecdóticos; son parte de la lucha de clases en la cual la oligarquía dominante necesita matar para legitimarse (p. 299). Esta nueva forma de entender los hechos es la que le permite al autor-narrador trazar "el retrato de la oligarquía dominante", los párrafos finales del epílogo de $1969^{146}$.

\footnotetext{
${ }^{145}$ Pienso que aquí también está el Walsh que años más tarde, aun después de la muerte de su hija en combate contra la policía y el ejército, sigue resistiendo con la escritura: funda ANCLA, la Agencia de Noticias Clandestina: "De estructura artesanal y alimentada sobre la base de información popular, ANCLA funcionó como una herramienta política ofensiva en el marco de la resistencia a la última dictadura militar (1976-1983)." (VINELLI, 2000, p. 11). Algunos críticos se refieren a la "fascinación de la muerte" en algunos textos de Walsh (en particular en "Carta a Vicki"). Pienso que si la fascinación fuese tal, la resistencia no se hubiese dado en el terreno de la escritura.

${ }^{146}$ Hay que tener en cuenta que, para cuando Walsh escribe este epílogo, ya había fundado, junto con Raimundo Ongaro, y dirigía el Semanario de la CGT de los Argentinos CGTA —Confederación General del Trabajo de los Argentinos, que fue la CGT "rebelde" fomentada por Perón para enfrentarse a la CGT burocratizada en manos de Vandor (GILLESPIE, 1998, p. 70)—. Además, había investigado y escrito ¿Quién mató a Rosendo? En la "Noticia preliminar" que abre el texto, dice Rodolfo Walsh: "Este libro fue
} 
Dije que en este epílogo, el narrador "prácticamente" ha dejado lo personal porque, ahora, la reflexión sobre la práctica "profesional", que había iniciado en el epílogo de 1964, se da como una justificación sobre el método adoptado, en su momento, para escribir Operación masacre. Así, comienza recordando la elección hecha en aquel momento - "renunciar al encuadre histórico, en beneficio del alegato particular"-y el porqué de dicha elección:

Se trataba de presentar a la Revolución Libertadora [...] el caso límite de una atrocidad injustificada, y preguntarles si la reconocían como suya, o si expresamente la desautorizaban. (p. 231)

Observemos cómo al recuperar el intento de diálogo con el Estado -indicado por el verbo "preguntar"- y el hecho de que sea un diálogo frustrado - "se trataba", ya no-, sin decirlo expresamente, el narrador pone de relieve el autoritarismo del gobierno; pero además prepara para que el lector concluya sobre el carácter criminal del mismo al enumerar los fusilamientos que se sucedieron a partir del 10 de junio de 1956 hasta que el general Valle se entrega: "Suman 27 ejecuciones en menos de 72 horas en seis lugares" (p. 233). Así, "a la luz del asesinato", dice el narrador, "se puede ir ordenadamente de menor a mayor y perfeccionar [...] el retrato de la oligarquía dominante." (p. 299).

El narrador ha comprendido la diferencia entre unas revoluciones y otras y ha construido un epílogo de tal manera que el lector también lo entienda. Si en el "Provisorio epílogo" las metía a todas en un mismo costal, ahora distingue la de Valle: "Los militares de junio de 1956, a diferencia de otros que se sublevaron antes y después, fueron fusilados porque pretendieron hablar en nombre del pueblo: más específicamente, del peronismo y la clase trabajadora" (p. 299).

En el párrafo final del "Retrato..." hay un referencia al trabajo de otros autores, quienes "vienen trazando una imagen cada vez más afinada de esa oligarquía..." (p. 300). En esta comparación y reflexión sobre el propio trabajo parece estar el origen de la forma que

inicialmente una serie de notas publicadas en el semanario 'CGT' a mediados de 1968 [...] Su tema superficial es la muerte del simpático matón y capitalista de juego que se llamó Rosendo García, su tema profundo es el drama del sindicalismo peronista a partir de 1955, sus destinatarios naturales son los trabajadores de mi país." (WALSH, 1984, p. 7). 
adopta el capítulo 37, con el que dará un fin "provisorio"147 a Operación masacre a partir de 1972.

“Aramburu y el juicio histórico” (de 1972)

Como ya fue señalado, para la edición de 1972 se mantiene parte del epílogo de la de 1969 y se sustituye la secuencia final, el "Retrato de la oligarquía dominante", por el capítulo 37, "Aramburu y el juicio histórico", que se puede leer como una ejemplificación, con nombre y apellido, de lo que antes se llamó en forma genérica "oligarquía"148.

El secuestro y la condena de Aramburu llevan al autor-narrador a hacer un análisis y un balance de lo que significó el régimen de la Revolución Libertadora para la historia del pueblo peronista, en particular, y del país, en general. El cambio de lugar del narrador se refleja, ahora, en la construcción de las causas de la ejecución de Aramburu mediante la indagación en la historia del país, en particular la del peronismo. La escritura, entonces, está despojada de toda referencia a lo personal y el texto se construye a la manera de una nota periodística, que además de informar, "forma" (consigna datos históricos, sociales, económicos).

El capítulo comienza con la noticia del secuestro y la condena a muerte de Aramburu, en 1970, por un comando montonero. En una oración, el narrador nos da todos los datos:

\footnotetext{
147 "Provisorio" porque dicha edición acaba con la secuencia final del guión cinematográfico de Operación masacre. La película se filmó en 1971, en la "clandestinidad que la dictadura de Lanusse impuso a la mayoría de las actividades políticas y a algunas actividades artísticas.". Entre imágenes de violencia — cuerpos en el basural de José León Suárez, cadáveres en "Plaza de mayo", "mártires", etc. - y de resistencia -manifestaciones, ocupación de fábricas, el Cordobazo, pintadas de los grupos armados peronistas "FAP [Fuerzas Armadas Peronistas], FAR [Fuerzas Armadas Revolucionarias], Montoneros"; etc.-. la voz en off de Julio Troxler [que en la película desempeña su propio papel] reflexiona sobre el significado del peronismo: "era una clase, era la clase trabajadora que no puede ser destruida [...] y el odio que ellos [los que los mataban] nos tenían era el odio de los explotadores por los explotados." (p. 244). La secuencia cierra con el optimismo y la esperanza puestos en la Patria Socialista que está siendo construida: "Lo que nosotros habíamos improvisado [la resistencia peronista después del golpe de 1955] en nuestra desesperación, otros aprendieron a organizarlo con rigor, a articularlo con las necesidades de la clase trabajadora, que en el silencio y el anonimato va forjando su organización independiente de traidores y burócratas, la larga guerra del pueblo / el largo camino / la larga marcha / hacia la Patria Socialista." (p. 247).

${ }_{148}$ Para cuando Walsh escribe este capítulo, ya es militante de las FAP, que habían surgido con la CGTA. (REDONDO, 2001).
} 
"quién", "qué”, "cuándo", "dónde” y "por qué”, y además sigue una especie de orden "jerárquico" que va poniendo en un lugar destacado los datos de la historia:

El 29 de mayo de 1970 un comando montonero secuestró en su domicilio al teniente general Aramburu. Dos días después esa organización lo condenaba a muerte y enumeraba los cargos que el pueblo peronista alzaba contra él. Los dos primeros incluían "la matanza de 27 argentinos sin juicio previo ni causa justificada” el 9 de junio de 1956. (p. 235)

Observemos el ordenamiento de las informaciones en la primera oración: comienza con la fecha "mítica", que evoca la "epopeya popular del Cordobazo"149, y finaliza refiriéndose al secuestrado, que trae a la memoria los fusilamientos de 1956. Se repite, prácticamente, la misma estructura en la segunda oración y cierra el párrafo con una única frase que contiene los cargos, que así retoma y refuerza el recuerdo activado en la primera oración. En el párrafo siguiente se repite el recurso a la historia; en dos oraciones el narrador nos comunica el nombre del comando, "Valle", cuándo fue ejecutado Aramburu y dónde se encontró el cadáver:

El comando llevaba el nombre del fusilado general Valle. Aramburu fue ejecutado a las 7 de la mañana del $1^{0}$ de junio y su cadáver apareció 45 días después en el sur de la provincia de Buenos Aires. (p. 235) [la cursiva es mía]

El narrador elige dar el nombre del comando junto con la noticia de la ejecución, reforzando la relación histórica anticipada en el título. Observemos, además, la elección de las palabras "fusilado" para Valle y "ejecutado" para Aramburu. "Ejecutado" Ileva implícita la idea de cumplimiento de una condena; "fusilado", no. Aunque ambos, Valle y Aramburu, hayan sido juzgados y condenados, en la elección de estas palabras con connotaciones diferentes, está indicada la diferencia de cargos contra los acusados y también de "jueces”. En esta elección de palabras está implícita la retórica de la lucha de

\footnotetext{
${ }^{149}$ En 1969, durante el gobierno de facto del general Onganía el descontento social era general, no sólo de la clase obrera: "La política de modernización de estructuras afectaba profundamente a los comerciantes y a las pequeñas y medianas empresas; la racionalización económica y la política salarial perjudicaban a los funcionarios y empleados del sector público. Los agricultores estaban inquietos por la preponderancia que se daba a la gran industria [...] En ausencia de mecanismos representativos que permitieran la canalización y la expresión de las distintas tensiones sociales, quedaba la calle. [En Córdoba] El 29 de mayo obreros y estudiantes unidos salieron a la calle. Sus organizaciones fueron rápidamente desbordadas por la violencia del motín. Ante la situación se dio intervención a las tropas. Entonces se produjo un levantamiento masivo en toda la ciudad [...] Los combates callejeros esporádicos duraron dos días, dejando un saldo de varias decenas de muertos. El gobierno no convenció fácilmente a la opinión pública de la tesis del complot extremista manipulado por agitadores extranjeros." (ROUQUIÉ, 1998, 284-285).
} 
clases que representan ambas muertes. Y esa retórica se hace más patente, en el párrafo siguiente, cuando el narrador comenta las diferentes repercusiones que tuvo la muerte de Aramburu:

El episodio sacudió al país de distintas maneras. El pueblo no lloró la muerte de Aramburu. El Ejército, las instituciones, la oligarquía elevaron un clamor indignado. Entre los centenares de protestas y declaraciones hay una que merece recordarse. Califica el hecho de "crimen monstruoso y cobarde, sin precedentes en la historia de la República' ${ }^{\prime 150}$. (p. 235)

"Sacudió", "clamor indignado", "crimen...", dan la dimensión de cómo la oligarquía y sus cómplices se refieren a sus muertos; en contraposición, la única oración para "el pueblo" se destaca "entre los centenares de protestas y declaraciones" y evoca, con el verbo "llorar", las manifestaciones de dolor por la muerte de Evita.

El capítulo cierra con un encadenamiento sistematizado de causalidades históricas, para la muerte de Aramburu ${ }^{151}$, que incluye un análisis económico y delimita las diferentes violencias: Aramburu, su gobierno y sus sucesores fueron ejecutores "de una política de clase cuyo fundamento - la explotación — es de por sí antihumano y cuyos episodios de crueldad devienen de ese fundamento como las ramas del tronco..." (p. 237).

Parece que el narrador encuentra una causa para la condena de Aramburu. El encuadre histórico, político, económico le dan la respuesta:

Quince años después será posible hacer el balance de esa política: un país dependiente y estancado, una clase obrera sumergida, una rebeldía que estalla por todas partes. Esa rebeldía alcanza finalmente a Aramburu, lo enfrenta con sus actos, paraliza la mano que firmaba empréstitos, proscripciones y fusilamientos. (p. 238)

Aun así, a pesar de la conexión histórica entre una muerte y las otras, es un hecho que la estructura inicial de Operación masacre no cambia. La forma como la novela fue concebida desde un principio - con el espanto y la sorpresa ante el crimen de Estado-

\footnotetext{
${ }^{150}$ Recordar que esa declaración es firmada, entre otros, por el coronel Fernández Suárez (p. 236).

151 Horacio González, en "Bastardillas y metamorfosis" dice que aquí "Walsh escribe una tesis sobre el drástico derecho a juzgar un crimen anterior, justificando los acontecimientos ocurridos en 1970 en la localidad bonaerense de Timote [donde fue juzgado y ejecutado Aramburu]." (GONZÁLEZ, 1998, p. 21)
} 
permanece inalterada en el tiempo. Operación masacre aparece así como testigo de la imposibilidad de reestablecer el equilibrio perdido; de volver a "las suaves, tranquilas estaciones" ${ }^{152}$.

${ }^{152}$ Esas palabras son la traducción que el propio autor hace del epígrafe de T. S. Eliot, que aparecía en la primera edición de Operación masacre. 


\section{PALABRAS FINALES}

Cuando Walsh se entera de los fusilamientos clandestinos de 1956, su mundo de seguridades se derrumba. Necesita entender qué significa ese crimen; intuye desde el principio que hay algo desproporcionado entre el acto de participar en el alzamiento y el castigo infringido a las víctimas. Procurando comprender, investiga y escribe. $\mathrm{Y}$ esa escritura no será solo de denuncia; será un espacio de búsqueda y de resistencia: búsqueda de respuestas para entender el desmoronamiento de su universo de seguridades; resistencia a la pérdida de valores que, hasta ese momento, le daban sentido a su vida.

El análisis de Operación masacre revela las elecciones hechas por Walsh para representar el descalabro del mundo que de repente lo asalta. Frente a un Estado que mata a sus ciudadanos, que aniquila a sus "enemigos" por mínima que sea su disidencia; frente a la arbitrariedad de la justicia que no castiga el crimen, el autor escribe movido por la urgencia, y Operación masacre asume una forma fragmentada. Pero su análisis permite reestablecer la línea de los acontecimientos entre mediados de los años ' 50 y los ' 70 . Si el crimen quedó impune y la herida siguió (sigue) abierta, es la causalidad histórica la que articula la trama de la novela.

A la negación de la identidad de ciudadanos de los fusilados, a la vida nuda, el autor opone un narrador que construye sistemáticamente la cotidianeidad y las pequeñas cosas del día a día de cada una de las víctimas; recupera sus palabras y su sintaxis en un movimiento en que les devuelve su singularidad, negándose a formar ese grupo como un grupo de sospechosos (así, los datos referidos a la militancia de los protagonistas se diluyen, pues nada existe que pueda justificar el crimen del Estado).

En dicha construcción, el narrador ocupará diferentes lugares, puntos de vista, ángulos en busca de un sitio "adecuado" donde alojar su voz; un lugar desde el cual poder cercar, 
aproximarse a lo incomprensible. Pero, a cada paso, se deparará con la insuficiencia de la palabra y las fórmulas explicativas, dejando constancia de la desproporción entre los hechos acontecidos y la capacidad abarcadora de cualquier materia significante a través de la exploración de tácticas y estrategias de persuasión y construcciones de perspectiva.

Lo que está en juego es la pérdida de valores que estructuraban la sociedad, está en juego la propia identidad. El crimen no se resuelve, y las respuestas no se encuentran (no las hay) y frente a esa realidad el autor resiste mediante la escritura y las sucesivas reescrituras al discurso legitimador del terrorismo de Estado.

Al llegar al final, me vuelve una y otra vez el recuerdo de la imagen de Walsh construida desde la crítica antimontonera posterior a la última dictadura (1976-1983), que habla de la "fascinación por la muerte" de los militantes de los años '70 y me pregunto si no es al contrario, si el incesante escribir y reescribir hasta el fin de su vida, no es una forma de militar contra la arbitrariedad, la injusticia; en fin, contra la muerte. 


\section{BIBLIOGRAFÍA}

\section{a) DE RODOLFO WALSH}

- "2-0-12 no vuelve". En: El violento oficio de escribir, obra periodística 1953-1977. Edición a cargo de Daniel Link, Prólogo de Rogelio García Lupo, Buenos Aires, Planeta, 1995.

- "Carta a mis amigos". En: Rodolfo Walsh, vivo. Compilación y prólogo de Roberto Baschetti. Buenos Aires, Ediciones de la flor, 1994.

- "Carta a Vicky". En: Rodolfo Walsh, vivo. Compilación y prólogo de Roberto Baschetti. Buenos Aires, Ediciones de la flor, 1994.

- "Carta abierta de un escritor a la Junta militar". En: Rodolfo Walsh, vivo. Compilación y prólogo de Roberto Baschetti. Buenos Aires, Ediciones de la flor, 1994.

- Caso Satanowsky. Edición y prólogo de Roberto Ferro. Tercera edición (primera edición crítica, corregida y aumentada), Buenos Aires, Ediciones de la flor, 1997.

- Cuento para tahúres y otros relatos policiales. Recopilación póstuma, $2^{a}$ edición. Buenos Aires, Ediciones de la flor, 1997.

- "Dos mil quinientos años de literatura policial". En: La Nación, Buenos Aires, 14/2/1954.

- El violento oficio de escribir. Obra periodística 1953-1977. Edición de Daniel Link. Con prólogo de Rogelio García Lupo. Buenos Aires, Planeta, 1998. $2^{a}$ edición.

- "El violento oficio de escritor". En: BASCHETTI, R. Rodolfo Walsh, vivo. Buenos Aires, Ediciones de la flor, 1994.

- Ese hombre y otros escritos personales. Edición de Daniel Link. Buenos Aires, Seix Barral, 1996.

- "Hoy es imposible en la Argentina hacer literatura desvinculada de la política". Reportaje de Ricardo Piglia a Rodolfo Walsh. En: BASCHETTI, R. Rodolfo Walsh, vivo. Buenos Aires, Ediciones de la flor, 1994.

- La granada. La batalla. Teatro. Buenos Aires, Ediciones de la flor, 1986.

- "Los documentos (las divergencias de Walsh con Montoneros)". En: BASCHETTI, R. Rodolfo Walsh, vivo. Buenos Aires, Ediciones de la flor, 1994.

- Los oficios terrestres. $3^{\text {a }}$ edición. Buenos Aires, Ediciones de la flor, 1997.

- "Memorias de infancia (el 37)". En: Caras y Caretas. Año 85, № 2210, mayo 1984. 
- "Nota autobiográfica". En: Textos de y sobre Rodolfo Walsh. VV.AA. Textos de y sobre Rodolfo Walsh. Editor Jorge Lafforgue, Buenos Aires, Alianza editorial, 2000.

- Operación masacre. Buenos Aires, Ediciones de la flor, s/f. A pesar de que en la edición que manejo no consta la fecha, pude comprobar que esta corresponde a la cuarta edición, de 1972.

- Operación masacre. Buenos Aires, Jorge Álvarez Editores, 1969.

- Operación masacre. Edición definitiva con un prólogo de Osvaldo Bayer. $5^{a}$ edición. Buenos Aires, Planeta, 1998.

- "Operación masacre. Un libro que no encuentra editor". En: Mayoría. Buenos Aires, 27 de mayo de 1957 a.

- "Operación masacre. Un libro que no encuentra editor". En: Mayoría. Buenos Aires, 3 de junio de $1957 \mathrm{~b}$.

- "Operación masacre. Un libro que no encuentra editor". En: Mayoría. Buenos Aires, 17 de junio de $1957 \mathrm{c}$.

- "Operación masacre. Un libro que no encuentra editor". En: Mayoría. Buenos Aires, 24 de junio de $1957 \mathrm{~d}$.

- “Operación masacre. Un libro que no encuentra editor". En: Mayoría. Buenos Aires, 1 de julio de 1957 e.

- "Operación masacre. Un libro que no encuentra editor". En: Mayoría. Buenos Aires, 8 de julio de $1957 \mathrm{f}$.

- "Operación masacre. Un libro que no encuentra editor". En: Mayoría. Buenos Aires, 15 de julio de $1957 \mathrm{~g}$.

- "Operación masacre. Un libro que no encuentra editor". En: Mayoría. Buenos Aires, 31 de julio de $1957 \mathrm{~h}$.

- Operación masacre. Un proceso que no ha sido clausurado. Buenos Aires, Ediciones Sigla, 1957.

- Operación masacre y el expediente Livraga. Buenos Aires, Continental Service, 1964.

- "Prólogo a Los que luchan y los que lloran". En: BASCHETTI, R. Rodolfo Walsh, vivo. Buenos Aires, Ediciones de la flor, 1994.

- ¿Quién mató a Rosendo? $7^{a}$ edición. Buenos Aires, Ediciones de la flor, 1997.

- Un kilo de oro. $2^{a}$ edición. Buenos Aires, Ediciones de la flor, 1996.

- Un oscuro día de justicia. Buenos Aires, Siglo XXI, 1973. 
- "Unas preguntas a Rodolfo Walsh sobre la novela policial". Entrevista de Ignacio Covarrubias. En: BASCHETTI, R. Rodolfo Walsh, vivo. Buenos Aires, Ediciones de la flor, 1994.

- Variaciones en rojo. Buenos Aires, Ediciones de la flor, 1998.

- "Yo también fui fusilado". En: Revolución nacional. Buenos Aires, 15 de enero de 1957. También consta en El violento oficio de escribir. Obra periodística 1953-1977. Edición a cargo de Daniel Link, Prólogo de Rogelio García Lupo, Buenos Aires, Planeta, 1995.

\section{b) SOBRE RODOLFO WALSH Y OPERACIÓN MASACRE}

- AGUILAR, G. M. "Rodolfo Walsh: escritura y Estado". En: Textos de y sobre Rodolfo Walsh. VV.AA. Textos de y sobre Rodolfo Walsh. Editor Jorge Lafforgue, Buenos Aires, Alianza editorial, 2000.

- ALABARCES, P. "Walsh: dialogismos y géneros populares". En: Textos de y sobre Rodolfo Walsh. VV.AA. Textos de y sobre Rodolfo Walsh. Editor Jorge Lafforgue, Buenos Aires, Alianza editorial, 2000.

- AMAR SÁNCHEZ, A. M. "La propuesta de una escritura (en homenaje a Rodolfo Walsh)". En: Rodolfo Walsh, vivo. Compilación y prólogo de Roberto Baschetti. Buenos Aires, Ediciones de la flor, 1994.

. "Vacíos del deseo: imagen y cuerpo de Evita". Trabajo presentado en el Encuentro Anual del New England Council of Latin American Studies, Massachusetts, 1997.

. El relato de los hechos. Rodolfo Walsh: testimonio y escritura. Rosario, Beatriz Viterbo Editora, 1992.

. "El sueño eterno de justicia". En: VV.AA. Textos de y sobre Rodolfo Walsh. Editor Jorge Lafforgue, Buenos Aires, Alianza editorial, 2000.

- ARIAS, O. L. "Rodolfo Walsh en lucha contra la trampa cultural". En: Caras y Caretas. Año 85, № 2210, mayo 1984.

- ARROSagaray, E. Rodolfo Walsh en Cuba. Agencia Prensa Latina, militancia, ron y criptografía. Buenos Aires, Catálogos, 2004.

- BASCHETTI, R. Rodolfo Walsh, vivo. Compilación y prólogo de Roberto Baschetti. Buenos Aires, Ediciones de la flor, 1994.

- BAYER, O. "Rodolfo Walsh, un historiador del presente". En: BASCHETTI, R. Rodolfo 
Walsh, vivo. Buenos Aires, Ediciones de la flor, 1994.

- BENEDETTI, M. "Rodolfo convirtió la realidad". En: BASCHETTI, R. Rodolfo Walsh, vivo. Buenos Aires, Ediciones de la flor, 1994.

- BOCCHINO, A. et alii. Rodolfo Walsh: del policial al testimonio. Mar del Plata, Estanislao Balder, 2004.

- BRACERAS, E. LEYTOUR y C. PITTELLA, S. "Walsh y el género policial". En: VV.AA. Textos de y sobre Rodolfo Walsh. Editor Jorge Lafforgue, Buenos Aires, Alianza editorial, 2000.

- BRUN, J. B. "Les presentamos a R. J. Walsh". En: BASCHETTI, R. Rodolfo Walsh, vivo. Buenos Aires, Ediciones de la flor, 1994.

"Reportaje a Walsh y, a través de él, a Cuba". En: BASCHETTI, R. Rodolfo Walsh, vivo. Buenos Aires, Ediciones de la flor, 1994.

- BURGOS, C. "Hay un fusilado que vive". En: Caras y Caretas. Año 85, № 2210, mayo 1984.

- CASUlLO, N. "Walsh y su pensamiento político en 1976". En: BASCHETTI, R. Rodolfo Walsh, vivo. Buenos Aires, Ediciones de la flor, 1994.

- CORTÁZAR, J. "La voz que no se apaga". En: BASCHETTI, R. Rodolfo Walsh, vivo. Buenos Aires, Ediciones de la flor, 1994.

- CRESPO. B. "El lector en el relato testimonial: 'en lo que a mí atañe, es cosa suya"'. En: El matadero. Revista crítica de literatura argentina. Buenos Aires, UBA, 1998.

"Rodolfo Walsh: acerca de Kafka y el lugar común". En: VV.AA. Textos de y sobre Rodolfo Walsh. Editor Jorge Lafforgue, Buenos Aires, Alianza editorial, 2000.

- DE GRANDIS, R. "La escritura del acontecimiento: implicaciones discursivas". En: VV.AA. Textos de y sobre Rodolfo Walsh. Editor Jorge Lafforgue, Buenos Aires, Alianza editorial, 2000.

- DEMARÍA, L. "Rodolfo Walsh, Ricardo Piglia, La tranquera de Macedonio y el difícil oficio de escribir". En: Revista Iberoamericana. Vol. LXVII, Núms. 194-195, EneroJunio 2001.

- DUHALDE, E. L. "Rodolfo Walsh: el secuestrado 26.001". En: BASCHETTI, R. Rodolfo Walsh, vivo. Buenos Aires, Ediciones de la flor, 1994.

- FERNÁNDEZ VEGA, J. "Literatura y legitimidad en Operación masacre, de Rodolfo Walsh". En: VV.AA., Cultura y política en los años 60. Buenos Aires, Oficina de 
publicaciones del CBC, Universidad de Buenos Aires, 1997.

- FERREYRA, L. "Rigor e inteligencia en la vida de Rodolso Walsh". En: BASCHETTI, R. Rodolfo Walsh, vivo. Buenos Aires, Ediciones de la flor, 1994.

- FERRO, R. "Las ediciones de Operación masacre". En: Espacios de crítica y producción. $\mathrm{N}^{0} 7$, Facultad de filosofía y letras de la Universidad de Buenos Aires, Buenos Aires, Nov-Dic, 1988a.

. "Rodolfo Walsh. La operación de Operación masacre." En: Página/12. Suplemento "Culturas", 18 de diciembre de 1988b, pp. 1-4.

. "Escritura periodística y poderes públicos. Las notas de Mayoría". En: Walsh, Rodolfo. Caso Satanowsky. Edición y prólogo de Roberto Ferro. Tercera edición (primera edición crítica, corregida y aumentada), Buenos Aires, Ediciones de la flor, 1997.

. "La literatura en el banquillo. Walsh y la fuerza del testimonio". En: Historia crítica de la literatura Argentina. La irrupción de la crítica. Dirigida por Noé Jitrik, directora del volumen Susana Cella. Buenos Aires, Emecé Editores, 1999.

. "Operación masacre: investigación y escritura". En: VV.AA. Textos de y sobre Rodolfo Walsh. Editor Jorge Lafforgue, Buenos Aires, Alianza editorial, 2000.

- FORD, A. "Ese hombre". En: VV.AA. Textos de y sobre Rodolfo Walsh. Editor Jorge Lafforgue, Buenos Aires, Alianza editorial, 2000.

. "Walsh: la reconstrucción de los hechos". En: Nueva novela latinoamericana II. La narrativa argentina actual. Buenos Aires, Paidós, s/f.

- GALEANO, E. "Un historiador de su propio tiempo". En: VV.AA. Textos de y sobre Rodolfo Walsh. Editor Jorge Lafforgue, Buenos Aires, Alianza editorial, 2000.

- GARCÍA LUPO, R. "El lugar de Walsh". En: VV.AA. Textos de y sobre Rodolfo Walsh. Editor Jorge Lafforgue, Buenos Aires, Alianza editorial, 2000.

- GARCÍA MÁRQUEZ, G. "Rodolfo Walsh: el escritor que se adelantó a la CIA". En: BASCHETTI, R. Rodolfo Walsh, vivo. Buenos Aires, Ediciones de la flor, 1994.

- GELMAN, J. "Nota VI". En: BASCHETTI, R. Rodolfo Walsh, vivo. Buenos Aires, Ediciones de la flor, 1994.

- GONZÁLEZ, H. "Bastardillas y metamorfosis". En: El matadero. Revista crítica de literatura argentina. Buenos Aires, UBA, 1998.

. "Quinta conferencia. (La idea de muerte en la Argentina)". En: Retórica y locura. Para una teoría de la cultura argentina. Buenos Aires, Ediciones Colihue, 2002. 
- KOHAN, M. "Saer, Walsh: una discusión política en la literatura". En: VV.AA. Textos de y sobre Rodolfo Walsh. Editor Jorge Lafforgue, Buenos Aires, Alianza editorial, 2000.

- KORN, G. "De historias y olvidos". En: El matadero. Revista crítica de literatura argentina. Buenos Aires, UBA, 1998.

- KRANIAUSKAS, J. "Rodolfo Walsh y Eva Perón: 'Esa mujer". En: VV.AA. Textos de y sobre Rodolfo Walsh. Editor Jorge Lafforgue, Buenos Aires, Alianza editorial, 2000.

- LAFFORGUE, J. "Informe para una biografía". En: Textos de y sobre Rodolfo Walsh. Editor Jorge Lafforgue, Buenos Aires, Alianza editorial, 2000.

- LÓPEZ, M. P. "Intelectuales orgánicos. Variaciones sobre tonos”. En: El matadero. Revista crítica de literatura argentina. Buenos Aires, UBA, 1998.

- MAYER, M. "Walsh: el descubrimiento de la víctima". En: El matadero. Revista crítica de literatura argentina. Buenos Aires, UBA, 1998.

- MIZRAJE, M. G. "Fusilado que vive". El ojo mocho, número 3, otoño, 1993.

- NEWMAN, K. La violencia del discurso. El estado autoritario y la novela política argentina. Buenos Aires, Catálogos Editora, 1991. Traducción Beba Eguía.

- ORGAMBIDE, P. "La narrativa de Walsh". En: BASCHETTI, R. Rodolfo Walsh, vivo. Buenos Aires, Ediciones de la flor, 1994.

- PAMPILLO, G. y URTASUN, M. "Operación masacre y las estrategias de persuasión". En: VV.AA. Textos de y sobre Rodolfo Walsh. Editor Jorge Lafforgue, Buenos Aires, Alianza editorial, 2000.

- PESCE, V. "Rodolfo J. Walsh, el problemático ejercicio del relato". En: VV.AA. Textos de y sobre Rodolfo Walsh. Editor Jorge Lafforgue, Buenos Aires, Alianza editorial, 2000.

- PIGLIA, R. "La mejor tradición argentina de la militancia intelectual". En: Caras y Caretas. Año 85, № 2210, mayo 1984.

. "Propuesta para el próximo milenio". En: El Clarín digital, 03-02-2000.

"Rodolfo Walsh y el lugar de la verdad". En: VV.AA. Textos de y sobre Rodolfo Walsh. Editor Jorge Lafforgue, Buenos Aires, Alianza editorial, 2000.

- RAMA, A. "Rodolfo Walsh: la narrativa en el conflicto de las culturas". En: Literatura y clase social. México, Folios Ediciones, 1983.

. "Las novelas policiales del pobre". En: Rodolfo Walsh, vivo. Compilación y prólogo de Roberto Baschetti. Buenos Aires, Ediciones de la flor, 1994.

- REDONDO, N. S. El compromiso político y la literatura. Rodolfo Walsh. Argentina 
1960-1977. La Pampa, Ameríndia, Universidad Nacional de Quilmes, 2001.

- ROGERS. G. "Revelación y secreto: políticas de la palabra en la escritura de Rodolfo Walsh". En: El matadero. Revista crítica de literatura argentina. Buenos Aires, UBA, 1998.

- ROMANO, E. "Modelos, géneros y medios en la iniciación literaria de Rodolfo J. Walsh". En: VV.AA. Textos de y sobre Rodolfo Walsh. Editor Jorge Lafforgue, Buenos Aires, Alianza editorial, 2000.

- SKLODOWSKA, E. "El arte de verdades parciales: testimonio noticiero". En: Testimonio hispanoamericano. Historia, teoría, poética. New York, Peter Lang, 1991.

- VERBITSKY, H. "De la vida y de la muerte". En: VV.AA. Textos de y sobre Rodolfo Walsh. Editor Jorge Lafforgue, Buenos Aires, Alianza editorial, 2000.

. "El relámpago de los ojos de Rodolfo Walsh". Caras y Caretas. Año 85, № 2210, mayo 1984.

- VINELLI, N. Ancla. Una experiencia de comunicación clandestina orientada por Rodolfo Walsh. Buenos Aires, La rosa blindada, 2000.

- VIÑAS, D. "Déjenme hablar de Walsh". En: Casa de las Américas 129, Año XXII, La habana, nov-dic 1981.

. "Rodolfo Walsh: el ajedrez y la guerra". En: Literatura argentina $y$ política Il, de Lugones a Walsh. Buenos Aires, Editorial Sudamericana, 1996.

- VV.AA. El matadero. Revista crítica de literatura argentina. Año I, N ${ }^{0} 1$. Buenos Aires, Instituto de Literatura Argentina "Ricardo Rojas", Facultad de Filosofía y Letras, UBA, 1998.

- VV.AA. "Rodolfo Jorge Walsh". En: Nuevo texto crítico N N 12/13, Año VI, Stanford, California, julio 1993-junio 1994.

- ZITO LEMA, V. "Vivir para los otros". En: BASCHETTI, R. Rodolfo Walsh, vivo. Buenos Aires, Ediciones de la flor, 1994.

\section{c) SOBRE TESTIMONIO}

\section{TEXTOS TEÓRICOS}

- ACHÚGAR, H. "Historias paralelas / historias ejemplares: la historia y la voz del otro". En: Revista de crítica literaria latinoamericana, $\mathrm{n}^{0} 36$, año XVII, Lima, Latinoamericana editores, 1992. 
- ADORNO, T. W. Dialéctica negativa. Madrid, Taurus ediciones, 1975.

Minima Moralia. São Paulo, Editora Ática, 1992.

Prismas. Crítica cultural y sociedade. São Paulo, Ática, 1998.

- ADORNO, T. W. et HORKHEIMER, M. Dialética do esclarecimento. Fragmentos filosóficos. Rio de Janeiro, Jorge Zahar Editores, 1985.

- AGAMBEN, G. Homo Sacer. El poder soberano y la nuda vida. Valencia, Pre-textos, 1998.

Infancia e historia. Destrucción de la experiencia y origen de la historia.

Buenos Aires, Adriana Hidalgo editora, 2001.

. Medios sin fin. Notas sobre la política. Valencia, Pre-textos, 2001.

Lo que queda de Auschwitz. Valencia, Pre-textos, 2000.

- AMÉRY, J. Más allá de la culpa y la expiación. Tentativas de superación de una víctima de la violencia. Valencia, Pre-textos, 2001.

- ANTELO, R. "Delectación morosa: imagen, identidad y testimonio". En: Punto de vista. $N^{\circ}$ 64, Buenos Aires, agosto de 1999.

- ARENDT, H. A condição humana. $10^{\circ}$ edição. Rio de Janeiro, Editora Forense universitária, 2002.

. Crises da república. São Paulo, Perspectiva, 1999.

. Eichmann em Jerusalém. Um relato sobre a banalidade do mal. São Paulo, Companhia das Letras, 2000.

O que é política? Fragmentos das obras póstumas compiladas por Ursula Ludz. Rio de Janeiro, Editora Bertrand Brasil, 2002.

. Origens do totalitarismo. Anti-semitismo imperialismo totalitarismo. Trad.

Roberto Raposo. São Paulo, Companhia das Letras, 2004.

. Verdade e política. Lisboa, Relógio D’Água Editores, 1995.

- ARRIGUCCI, D. "Gabeira em dois tempos". Em: Enigma e comentário. Ensaios sobre literatura e experiência. São Paulo, Companhia das letras, 1987.

- BATAILLE, G. A literatura e o mal. Lisboa, Passagens, 1998.

- BENJAMIN, W. "El narrador". En: Para una crítica de la violencia y otros ensayos. España: Taurus, 1999.

. "Para una crítica de la violencia". En: Para una crítica de la violencia y otros ensayos. Iluminaciones IV. España, Taurus, 1999.

- BEVERLEY, J. "Introducción". En: Revista de crítica literaria latinoamericana, $n^{0} 36$, 
año XVII, Lima, Latinoamericana editores, 1992.

. "El testimonio en la encrucijada". En: Revista Iberoamericana, Vol. LIX, № 164-5, julio-diciembre de 1993.

. "Respuesta a Mario Cesáreo". En: Revista Iberoamericana, Vol. LXII, № 174, enero-marzo de 1996.

- BOSI, A. "A escrita do testemunho em Memórias do cárcere". En: Estudos Avançados, Vol. 9, $N^{0} 23$, janeiro-abril, 1995.

- BOSI, E. "O campo de Terezin". Em: Estudos Avançados 37. Dossiê Memória. São Paulo, Instituto de Estudos Avançados, 1999.

- CARR, R. "Re(-)presentando el testimonio: notas sobre el cruce divisorio primer mundo/tercer mundo". En: Revista de crítica literaria latinoamericana, $\mathrm{n}^{0} 36$, año XVII, Lima, Latinoamericana editores, 1992.

- CARUTH, C. "Modalidades do despertar traumático (Freud, Lacan e a ética da memória)". Em: Catástrofe e representação. São Paulo, Escuta, 2000.

- CASA DE LAS AMÉRICAS. "Casa de las Américas y la 'creación' del género testimonio". En: Casa de las Américas, № 200, julio-septiembre de 1995.

- CORNEJO POLAR, A. "El indigenismo y las literaturas heterogéneas". En: Revista de crítica literaria latinoamericana. Año II, № 3, Lima, $1^{\text {er }}$ semestre de 1976.

- DE MARCO, V. "A literatura de testemunho e a violência de Estado". Em: Revista Lua Nova. Número 63, 2004, São Paulo.

. "Campo francés: Max Aub y la literatura de testimonio". En: Quaderni del

Dipartimento di Linguistica 21. Università della Calabria, Serie letteratura. Rende, Centro Ediotoriale e Librario, 2002.

. "Historia de Jacobo: La imposibilidad de narrar". En : Actas del Congreso Internacional "Max Aub y el laberinto español", Valencia, 1996.

. "La hora violeta: a impossibilidade de compreender". Em: Hispanismo 2000. Vol. 2. Ministerio de Educación, Cultura y Deporte / Associação Brasileira de Hispanistas, 2001.

- "Literatura de testemunho: aproximação a Ferreira Gullar". Em: SILVEIRA MARTINS, D. Seminário brasileiro de crítica literária. Seminário de crítica do Rio Grande do Sul. Jornada internacional de narratologia. Porto Alegre: EDIPUC RS, 2001.

- DYMetMAN, A. Uma arquitetura da indiferença. A república de Weimar. São Paulo, 
Editora Perspectiva, 2002.

- EPPLE, J. A. "Acercamiento en la literatura testimonial en Chile". En: Revista Iberoamericana, Vol. LX, № 168-169, julio-diciembre de 1994.

- FEINMANN, J. P. La sangre derramada. Ensayo sobre la violencia política. Buenos Aires, Ariel, 1998.

- FELMAN, S. "Educação e crise, ou as vicissitudes do ensino". Em: Catástrofe e representação. São Paulo, Escuta, 2000.

- FLORES, L. "Ideología y cultura en la autobiografía chicana". En: Revista de crítica literaria latinoamericana, $n^{0}$ 36, año XVII, Lima, Latinoamericana editores, 1992.

- FORSTER, R. "La política como barbarie: una lectura de Homo Sacer de Giorgio Agamben". En: Sociedad, № 19, diciembre de 2001. Walter Benjamin y el problema del mal. Buenos Aires, Altamira, 2001.

- FOUCAULT, M. Historia de la sexualidad. I - La voluntad de saber. Capital Federal, Siglo XXI editores Argentina, 2002.

- Vigilar y castigar. Nacimiento de la prisión. Buenos Aires, Siglo veintiuno editores argentina, 2002.

- FRANCO, J. "Si me permiten hablar: la lucha por el poder interpretativo". En: Revista de crítica literaria latinoamericana, $\mathrm{n}^{0} 36$, año XVII, Lima, Latinoamericana editores, 1992.

- GAGNEBIN, J. M. "A (im)possibilidade da poesia". Em: Revista Cult. Número 23, São Paulo.

. "Memória, história, testemunho". Em: BRESCIANI, S., NAXARA, M. (org.). Memória e (res)sentimento. Indagações sobre uma questão sensível. Campinas: Ed. da Unicamp, 2001.

. "Palavras para Hurbinek". Em: Catástrofe e representação. São Paulo, Escuta, 2000.

- GALICH, M. "Para una definición del género testimonio". En: Casa de las Américas. Año XXXVI, № 200, La Habana, julio-septiembre de 1995.

- HA KANG, J. Novela, testimonio y memoria. Apuntes sobre recuerdo de la muerte de Miguel Bonasso. Dissertação de mestrado apresentada no Departamento de Língua espanhola e literaturas espanhola e hispano-americana da Faculdade de Filosofia, Letras y Ciências Humanas da Universidade de São Paulo, 2003.

- HALBWACHS, M. A memória coletiva. São Paulo, Edições Vértice, 1990. 
- HARTMAN, G. "Holocausto, testemunho, arte e trauma". Em: Catástrofe e representação. São Paulo, Escuta, 2000.

- JAMESON, F. "De la sustitución de importaciones literarias y culturales en el tercer mundo: el caso del testimonio". En: Revista de crítica literaria latinoamericana, $n^{0} 36$, año XVII, Lima, Latinoamericana editores, 1992.

- KEHL, M. R. "O sexo, a morte, a mãe e o mal". Em: Catástrofe e representação. São Paulo, Escuta, 2000.

- KERTÉSZ, I. Un instante de silencio en el paredón. El holocausto como cultura. Barcelona, Herder, 1999.

- KOSELLECK, R. "Terror y sueño. Notas metodológicas para las experiencias del tiempo en el Tercer Reich". En: Futuro pasado. Para una semántica de los tiempos históricos. Barcelona, Paidós, 1993.

- LACOUE-LABARTHE, P. y NANCY, J. L. O mito nazista. São Paulo, lluminuras, 2002.

- LEVINAS, E. Algunas reflexiones sobre la filosofía del hitlerismo. Seguido de un ensayo de Miguel Abensour: El mal elemental. México, Fondo de Cultura Económica, 2002.

- LOZANO AGUILAR, A. (coord.) La memoria de los campos. El cine y los campos de concentración nazis. Valencia, Ediciones de la Mirada, 1999.

- MESNARD, P. y KAHAN, C. Giorgio Agamben a l'epreuve d'Auschwitz. Temoignages / interpretations. Paris, Éditions Kimé, 2001.

- MORAÑA, M. "Documentalismo y ficción: testimonio y narrativa testimonial hispanoamericana en el siglo XX". En: PIZANO, A. Palavra, literatura e cultura. Vol. 3. Memorial, São Paulo, 1995.

- NESTROVSKI, A. y Seligman-Silva, M. "Apresentação". Em: Catástrofe e representação. São Paulo, Escuta, 2000.

- NETROVSKI, Artur. "Vozes de crianças". Em: Catástrofe e representação. São Paulo, Escuta, 2000.

- PÁL PELBART, P. "Cinema e holocausto". Em: Catástrofe e representação. São Paulo, Escuta, 2000.

- RAMA, A. et alii. "Conversación en torno al testimonio". En: Casa de las Américas № 200, La Habana, julio-septiembre de 1995.

- ROBERT MORAES, E. "A memória da fera". Em: Catástrofe e representação. São Paulo, Escuta, 2000. 
- SÁNCHEZ-BIOSCA, V. "Funcionarios de la violencia. La violencia y su imagen en los campos de exterminio". Documentos de trabajo. En: Colección Eutopías. Vol. 183, Valencia, Ediciones Epistemel, 1997.

- SARLO, B. "Una alucinación dispersa en agonía”. En: Revista Punto de vista. 25 años, números 1 al 75, 1978-2003. Edición electrónica, Buenos Aires.

. Una modernidad periférica: Buenos Aires 1920 y 1930. Buenos Aires, Nueva Visión, 2003.

- SCHWARTZ, J. Vanguardas lantino-americanas. Polêmicas, manifestos e textos críticos. São Paulo, Editora da Universidade de São Paulo: lluminuras: FAPESP, 1995.

- SELIGMAN SILVA, M. "A história como trauma". Em: Catástrofe e representação. São Paulo, Escuta, 2000.

. "Auschwitz: história e memória". Em: Pro-Posições. Vol. 11, № 2 (32), julho 2000.

. História, memória, literatura. O testemunho da era das catástrofes. Campinas, Unicamp, 2003.

"Literatura e trauma: um novo paradigma". Em: Revista di studi portoghesi e brasiliani. Pisa, Instituti Editoriali e Poligrafici Internazionali, 2001.

. "Zeugnis' e 'Testimonio': um caso de intraduzibilidade entre conceitos".

Em: Literatura e Autoritarismo. №22, janeiro/junho de 2001.

- SEMPRUN, J. Mal et modernité: le travail de l'histoire suivi de “... vous avez une tombe dans les nuages...". Climats, 1995.

- SILVA, L. M. "Formas literárias e testemunho: a representação da catástrofe em Max Aub". Em: Hispanismo 2002. Volume 2. São Paulo: ABH, 2004.

. O desaparecimento do poder do narrador. A representação do universo concentracionário em treze contos de "El laberinto mágico" de Max Aub. Dissertação de mestrado apresentada no Departamento de Língua espanhola e literaturas espanhola e hispano-americana da Faculdade de Filosofia, Letras y Ciências Humanas da Universidade de São Paulo, 2002.

. "O universo concentracionário nos contos de Max Aub". Em: Hispanismo 2000. Vol. 2. São Paulo, ABH, 2001.

- SKLODOWSKA, E. "El arte de verdades parciales: testimonio noticiero". En: Testimonio hispanoamericano. Historia, teoría, poética. New York, Peter Lang, 1991.

- SOMMER, D. "Sin secretos". En: Revista de crítica literaria latinoamericana, $n^{0} 36$, año 
XVII, Lima, Latinoamericana editores, 1992.

- STEELE, C. "Testimonio y autor/idad en Hasta no verte Jesús mío de Elena Poniatowska". En: Revista de crítica literaria latinoamericana, $n^{0} 36$, año XVII, Lima, Latinoamericana editores, 1992.

- TENORIO DA MOTTA, L. "Céline diante do extremo". Em: Catástrofe e representação. São Paulo, Escuta, 2000.

- VERA LEÓN, A. "Hacer hablar: La transcripción testimonial". En: Revista de crítica literaria latinoamericana, $\mathrm{n}^{0}$ 36, año XVII, Lima, Latinoamericana editores, 1992.

- VIDAL-NAQUET, P. Los asesinos de la memoria. Madrid, Siglo veintiuno editores, 1994.

- VV.AA. "La casa de las Américas y la 'creación del género testimonio". En: Casa de las américas, 200, Año XXXVI. La Habana, Jul-Sep 1995.

- VV.AA. Pulsional Revista de psicanálise. Ano XI / XII, N0116-117. São Paulo, Livraria Pulsional, Dic. 1998, Ene. 1999.

- VV.AA. Revista de crítica literaria latinoamericana. Año XVIII, $\mathrm{N}^{0}$ 36. Lima, Latinoamericana Editores, 1992.

- WALDMAN, B. y DE MARCO, V. "A experiência do horror". Em: Cult. Revista brasileira de literatura. Ano V, № 53.

- WALTER, M. "El cimarrón en una cimarronada. (Nuevos motivos para rechazar un texto y de la forma como éste se nos impone)". En: Revista de crítica literaria latinoamericana, $\mathrm{n}^{0}$ 36, año XVII, Lima, Latinoamericana editores, 1992.

- YÚDICE, G. "Testimonio y concientización". En: Revista de crítica literaria latinoamericana, $\mathrm{n}^{0}$ 36, año XVII, Lima, Latinoamericana editores, 1992.

- ZIMMERMAN, M. "El otro de Rigoberta: Los testimonios de Ignacio Bizarro Ujpán y la resistencia indígena en Guatemala". En: Revista de crítica literaria latinoamericana, $\mathrm{n}^{0}$ 36, año XVII, Lima, Latinoamericana editores, 1992.

\section{TEXTOS TESTIMONIALES}

- ANGUITA, E. y CAPARRÓS, M. La voluntad (3 vols.), Buenos Aires, Norma, 1997-8.

- AUB, M. Campo francés. Torino, Ruedo Ibérico, 1965. . "Manuscrito cuervo: Historia de Jacobo". Enero sin nombre. Los relatos completos del laberinto mágico. Barcelona, Alba editorial, 1995. 
- BARNET, M. Biografía de un cimarrón. Barcelona, Ariel, 1968.

- BONASSO, M. Diario de un clandestino. Buenos Aires, Planeta, 2000. . Recuerdo de la muerte. Buenos Aires, Planeta, 1994.

- BURGOS, E. Me llamo Rigoberta Menchú y así me nació la conciencia. $16^{\circ}$ edición, México, DF, Siglo XXI editores, 2000.

- CONADEP. Nunca más. Informe de la Comisión Nacional sobre la Desaparición de Personas. Buenos Aires, Eudeba, 1984.

- CONSTANTE, M. Los años rojos. Holocausto de los españoles. Zaragoza, Editorial Pirineo, 2000.

- DIEZ, R. Los compañeros. La Plata, Canto Rodado, 2000.

- FERREIRA GULlAR. Rabo de foguete. Os anos de exílio. Rio de Janeiro, Editora Revan, 1998.

- GABEIRA, F. O que é isso, companheiro? São Paulo, Companhia das letras, 2001.

- JOSÉ, E. Carlos Marighela. O inimigo número um da ditadura militar. São Paulo, Sol e Chuva, 1997.

- LACAPRA, D. Representing the Holocaust. History, Theory, Trauma, New York, Cornell University Press, 1996. . History and Memory after Auschwitz. Ithaca, Cornell U. Press, 1998.

- LEÑERO, V. Asesinato. El doble crimen de los Flores Muñoz. México, DF, Plaza y Valdés, 1997.

- LEVI, P. A tabela periódica. Rio de Janeiro, Relume Dumará, 1994. A trégua. São Paulo, Companhia das letras, 1997. É isto um homem? Rio de Janeiro, Rocco, 1997. . Historias naturales. Madrid, Alianza, 1988. Os afogados e os sobreviventes. São Paulo, Paz e Terra, 1990.

- LEWIS, O. Los hijos de Sánchez. México, DF, Grijalbo, 1999.

- LIMA, S. Zé. Belo Horizonte, Mazza, 1998.

- MALRAUX, A. La esperanza. Barcelona, Edhasa, 1989.

- MARTíNEZ, T. E. La pasión según Trelew. Buenos Aires, Planeta, 1997.

- PONIATOWSKA, E. La noche de Tlatelolco. $2^{\circ}$ edición corregida. México, DF, Ediciones Era, 1998.

- ROA BASTOS, A. Contravida. Santafé de Bogotá, Editorial Norma, 1995.

- ROIG, M. La hora violeta. Barcelona, Plaza y Janés Editores, 1993. 
- SEMPRÚN, J. Autobiografía de Federico Sánchez. Barcelona, Planeta, 1995.

. La escritura o la vida. Barcelona, Fábula Tusquets, 1997.

- SENDER, R. J. Viaje a la aldea del crimen. (Documental de Casas Viejas). Madrid, Ediciones Vosa, , 2000.

- TAMBURRINI, C. M. Pase libre. La fuga de la mansión Seré. Buenos Aires, Ediciones Continente, 2002.

- timerman, J. Preso sin nombre, celda sin número. Buenos Aires, Ediciones de la flor, 2000.

- UNIÓN DE TRABAJADORES DE PRENSA DE BUENOS AIRES. Los periodistas desaparecidos. Las voces que necesitaba silenciar la dictadura. Buenos Aires, Grupo Editorial Norma, 1998.

- URONDO, F. (entrevistador). La patria fusilada. Testimonio de María Antonia Berger, Alberto Miguel Camps y Ricardo René Haidar. Argentina, Ediciones de Crisis, 1973.

- VALDÉS, H. Tejas Verdes. Diario de un campo de concentración en Chile. Barcelona, Editorial Laia, 1978.

- VERBITSKY, H. Ezeiza. Segunda edición. Buenos Aires, Editorial Planeta argentina, 1998.

- VERDUGO, P. La caravana de la muerte. Los zarpazos del puma. Santiago, Ediciones Chile-América CESOC, 2001.

- WALD, P. Pesadilla. Novela-crónica de la Semana Trágica (1919). Buenos Aires, Ameghino, 1998.

- WILKOMIRSKI, B. Fragmentos. Memórias de uma infancia 1939-1948. São Paulo, Companhia das letras, 1998.

- ZAMORANO, C. M. Prisionero político. Testimonio sobre las cárceles políticas argentinas. Buenos Aires, Ediciones Estudio, 1984.

\section{d) SOBRE EL CONTEXTO}

- ABÓS, A. A. T. Vandor. Sindicatos y peronismo. Los nombres del poder. Buenos Aires, Fondo de Cultura Económica, 1999.

- Altamirano, C. Peronismo y cultura de izquierda. Buenos Aires, Temas grupo editorial, 2001. 
- BASCHETTI, R. (comp.). De Cámpora a la ruptura. Documentos. 1973-1976. Vol. I. La Plata, Editorial de la campana, 1996.

- BUCHRUCKER, C. Nacionalismo y peronismo. La argentina en la crisis ideológica mundial (1927-1955). Buenos Aires, Editorial Sudamericana, 1999.

- CARNEVALE, S. La patria periodística. Buenos Aires, Ediciones Colihue, 1999.

- CELLA, S. "La erupción de la crítica". En: JITRIK, N. (org.) Historia Crítica de la literatura argentina. La irrupción de la crítica. Buenos Aires, Emecé, 1999.

- CIRIA, A. Política y cultura popular: la Argentina peronista 1946-1955. Buenos Aires, Ediciones de la flor, 1983.

- DE RIZ, L. La política en suspenso: 1966-1976. Buenos Aires, Paidós, 2000.

- GALASSO, N. Cooke: de Perón al Che. Una biografía política. Rosario, Homo Sapiens Ediciones, 1997.

- GILlespie, R. Soldados de Perón. Los montoneros. Trad. Antoni Pigrau. Buenos Aires, Grijalbo, 1998.

- HALPERIN DONGHI, T. Argentina en el callejón. Buenos Aires, Ariel, 1995.

La larga agonía de la Argentina peronista. $3^{\circ}$ edición, Buenos Aires, Ariel, 1998.

- LAFFORGUE, J. "La narrativa argentina actual". En: Nueva novela latinoamericana II. La narrativa argentina actual. Buenos Aires, Paidós, s/f

- MURMIS, M. y PORTANTIERO, J. C. Estudios sobre los orígenes del peronismo. Buenos Aires, Siglo XXI, 1987.

- O'DONNEL, G. "Argentina: a macropolítica e o cotidiano". Em: Revista Lua Nov. Volume 4, número 2, abril-junho/88, número 14. São Paulo.

- PLOTKIN, M. Mañana es San Perón. Propaganda, rituales políticos y educación en el régimen peronista (1946-1955). Buenos Aires, Espasa Calpe, 1994.

- POTASH, R. A. El ejército y la política en la Argentina 1928-1945. De Yrigoyen a Perón. Traducción de Aníbal Leal. Buenos Aires, Sudamericana, 1984. . El ejército y la política en la Argentina 1945-1962. De Perón a Frondizi. Traducción de Enrique Tejedor. Buenos Aires, Sudamericana, 1984. El ejército y la política en la Argentina 1962-1973. De la caída de Frondize a la restauración peronista. Primera parte, 1962-1966.. Traducción de Elvio Gandolfo. Buenos Aires, Sudamericana, 1994. 
El ejército y la política en la Argentina 1962-1973. De la caída de Frondize a la restauración peronista. Segunda parte, 1966-1973.. Traducción de Elvio Gandolfo. Buenos Aires, Sudamericana, 1994.

- QUATTROCCHI-WOISSON, D. Un nationalisme de déracinés. L'Argentine pays malade de sa mémoire. Paris, Editions du Centre National de la Recherche Scientifique, 1992.

- RODRíGUEZ, E. (comp). Contra la prensa. Antología de diatribas y apostillas. Buenos Aires, Colihue, 2001.

- ROMERO, L. A. Breve historia contemporánea argentina. México, Fondo de Cultura Económica, 1994.

- ROUQUIÉ, A. Poder militar y sociedad política en la Argentina, Vol I y II. Buenos Aires, Emecé, 1998.

- ROZITCHNER, L. Perón: entre la sangre y el tiempo. Lo inconciente y la política. Tomo I, del duelo a la política: Freud y Clausewitz. Buenos Aires, Catálogos.

. Perón: entre la sangre y el tiempo. Lo inconciente y la política. Tomo II, de la sangre a la política. Buenos Aires, Catálogos, 2000.

- SAÍTTA, S. "Introducción". En: JITRIK, N. (org.) Historia Crítica de la literatura argentina. El oficio se afirma. Buenos Aires, Emecé, 2004.

- SAlOMONE, F. Maten al mensajero. Periodistas asesinados y desaparecidos desde Mariano Moreno hasta José Luis Cabezas. Buenos Aires, Sudamericana,1999.

- VV.AA Cultura y política en los años '60. Buenos Aires, Oficina de publicaciones del CBC, Universidad de Buenos Aires, 1997.

\section{e) OTRAS REFERENCIAS}

- ARFUCH, L. El espacio biográfico. Dilemas de la subjetividad contemporánea. Buenos Aires, Fondo de Cultura Económica, 2002.

- BOOTH, W. C. A retórica da ficção. Trad. Maria Teresa H. Guerreiro. Lisboa, Arcádia, 1980.

- ESPASA. Diccionario de la lengua española. Real Academia Española. Edición en CDROM.

- MUDROVCIC, M. E. "En busca de dos décadas perdidas: la novela latinoamericana de los años 70 y 80". En: Revista Iberoamericana, números 164-165, julio/diciembre 1993, Pittsburg. 
"Mundo nuevo: hacia la definición de un modelo discursivo". En: Revista Nuevo texto crítico. Vol. VI, oㅜ 11, primer semestre, California.

- PANESI, J. Críticas. Buenos Aires, Vitral, 2000.

- SAER, J. J. El concepto de ficción. Buenos Aires, Ariel, 1997.

- SM. Clave diccionario de uso del español actual. Madrid, SM, 2000.

- TROXLER, J. www.lucheyvuelve.com.ar

- TZVETAN Todorov. "Tipologia do romance policial". Em: As estruturas narrativas. São Paulo, Perspectiva, 1979, (p. 93-104). 
Anexo 


\title{
LOS ASESINATOS DE JUNIO DEL 56 \\ EN EL TESTIMONIO DE UN MILITANTE \\ DE LA RESISTENCIA
}

\author{
JULIO TROXLER
}

El largo camino de la resistencia peronista tuvo como doloroso antecedente, clave para la ininterrumpida política de terror por parte de las fuerzas antipatrióticas y antipopulares, el bombardeo indiscriminado a Plaza de Mayo en 16 de junio del 55. Ese hecho de barbarie no consiguió despertar una conciencia súbita y exacta de lo que debería enfrentar el Movimiento Peronista desde ese momento en adelante. Todo fue demasiado inicuo e inesperado. El objetivo de aplastar, definitivamente la manifestación de la voluntad de las masas buscó alcanzarse a través de una represalia sangrienta.

Debió pasar un año antes de que el pueblo, ya mínimamente organizado, tuviera otra prueba de la naturaleza de esas fuerzas. El bombardeo anterior formaba parte de una política; se trataba de escarmentar, y por ello los patriotas civiles y militares intervinientes en el frustrado intento encabezado por los generales Valle y Tanco sólo podían encontrar una reedición de los sucesos del 16 de junio de 1955. Quienes actuaban como militantes a un nivel de organizaciones de masas, aquellos encargados de asegurar nuevamente en Plaza de Mayo la presencia del pueblo peronista, sufrieron (al igual que los militares conjurados para la defensa del país) el más despiadado tratamiento. La supresión de todo estado de derecho se puso cruelmente de manifiesto en los asesinatos que siguieron al intento insurreccional.

Esos asesinatos, 27 en total, se cumplieron por orden directa del Poder Ejecutivo, lo cual da más razón a lo que se afirmaba en la proclama revolucionaria del Movimiento de la Recuperación Nacional suscripta por los generales Valle y Tanco. Se trataba de una acción sólo propia de la "minoría despótica encaramada y sostenida por el terror y la violencia en el poder." Uno de los grupos civiles actuantes en esa oportunidad fue el de la localidad de Florida. Contra él se ensañó la represión a través del brazo ejecutor del coronel Desiderio Fernández Suárez, jefe de Policía de la Provincia de Buenos Aires, y 
del jefe de la Unidad Regional de San Martín, Rodríguez Moreno, actualmente jefe de vigilancia de la empresa de la Banca Morgan, Standard Electric. Algunos de sus integrantes habrían de morir baleados en los basurales de José León Suárez. El Movimiento Nacional Peronista en su conjunto tardó en incorporar ese y otros hechos similares con todas sus implicancias. Aún hoy no tiene a mano su historia, elemento imprescindible para evaluar los errores, la efectividad de los métodos propios y de los del enemigo, las necesidades que plantea cada nueva etapa del desarrollo. En este sentido, debemos aún recuperar cabalmente todos aquellos testimonios de compañeros de lucha, testimonios que se han perdido o por lo menos no se han difundido suficientemente. Lo que sigue es precisamente uno de esos testimonios, Julio Troxler militaba en 1955 en el grupo de la localidad de Florida, y su relato permite captar como vivió y soportó esas primeras jornadas de la resistencia un activista de base.

Comité de Redacción

-Julio, ¿cómo comenzó a desarrollarse la resistencia?

J. T. - La resistencia comenzó en forma espontánea, sin organización centralizada. Fue una acción tendiente a oponerse, por todos los medios, a quienes detentaban el poder como consecuencia del golpe militar de setiembre de 1955. En cada lugar se emprendía la realización de panfletos, de pintadas y también de acciones violentas, todo acorde con la característica de cada compañero, dispuesto a encarar una u otra tarea. Era una forma de resistir a los usurpadores. No hubo tampoco conducción centralizada en ese momento, porque si bien es cierto que llegaron algunas cintas grabadas de Perón, éstas fueron difundidas en un ámbito muy reducido y la resistencia fue mucho más allá de ese ámbito. Lo que la define es precisamente su espontaneidad. Fue algo instintivo, de defensa. La gente, en su impotencia, sentía que había perdido algo, que se lo habían quitado por la fuerza. Estaba vivo, brutal, el recuerdo del 16 de Junio de 1955 y todos los hechos de barbarie entre los cuales el más inicuo fue el bombardeo indiscriminado del pueblo en Plaza de Mayo.

-¿Quiere decir que la gente, se encontró sin otra experiencia que el bombardeo y los ametrallamientos del 16 de junio y el derrocamiento de un gobierno legítimo que sentía 
como suyo y que era suyo, o sea se encontró frente a la violencia del régimen y tuvo que emprender una acción defensiva sin nada preparado para llevarla a cabo?

J. T. - Así es, porque a pesar de la experiencia vivida en 16 de junio de 1955 no fue tomado en cuenta en ningún momento. No hubo ningún plan a nivel gremial o político para organizar la defensa. Nadie compartía la creencia de que iban a darse males mayores. La gravedad de los sucesos del 55 nos debía haber advertido - yo estuve presente en el bombardeo de Plaza de Mayo- que estos asesinos, uniformados y civiles, estaban dispuestos a cualquier cosa con tal de tener el poder. Más aún, los hechos del 55 indicaban fundamentalmente la voluntad de castigar y aterrorizar al pueblo con un baño de sangre.

- ¿Conocía a alguien que previese la dificultades de recuperar el poder?

J. T. - No, en aquella época no. El fervor era general. Se habían producido huelgas muy importantes, casi totales. Todo estaba paralizado, y los tanques y el ejército en la calle, de manera que no se pensó en eso. El peronismo había demostrado gran fuerza como movimiento social, como movimiento obrero. Las huelgas eran verdaderamente aguerridas. En general la mayoría ni se imaginaba lo que venía. Parece que uno de los pocos esclarecidos era Cooke.

- ¿El general Valle pensó que la revolución triunfaría fácilmente?

J. T. - Sí, pensaba inclusive que había que evitar todo tipo de violencia, de desmanes, y sencillamente llevar la gente a Plaza de Mayo, para que, triunfante la revolución, se reclamara la presencia de Perón en el país. El general Valle dio instrucción de movilizar a los compañeros que en gran cantidad teníamos organizados para concurrir a Plaza de Mayo. La revolución iba a ser poderosa. Creíamos, por otra parte, que Aramburu y Rojas no resistirían. Fundamentalmente sabíamos que no eran ejemplos de valor: habían llegado al poder como consecuencia de una asonada vergonzosa. Los que pelearon fueron otros. Si recordamos fue Lonardi el hombre que afrontó los riesgos y los demás jugaron desde afuera de la cancha. 
- ¿Se intentaría un nuevo 17 de Octubre?

J. T. - Exacto. Se buscaba producir un hecho de signo revolucionario peronista. La participación popular se iniciaba desde el vamos, ya con la concurrencia a Plaza de Mayo y con las distintas actividades enumeradas. El levantamiento fue mucho más grande y serio de lo que el propio régimen nos lo hizo creer. No fue, como se dijo, una cosa de locos, de tres tipos en desacuerdo...

- También la interpretación tradicional del 45, la de los historiadores y cronistas contrarios a la causa popular, tiene la característica de presentar los hechos reduciéndolos a una serie de coincidencias donde la actuación del pueblo no habría sido protagónica.

J. T.- Claro, y en esta oportunidad había miles y miles comprometidos en todo el país para participar activamente: por ejemplo, cortar la luz, interrumpir determinados servicios, entre ellos los ferrocarriles eléctricos, ocupar la zona del puerto, etc. O sea que estaba el pueblo. Lo que falló de inmediato fue la parte militar. Tan es así que se limitó a valientes levantamientos en La Plata y en La Pampa, levantamientos por demás precarios. De manera que lo demás no se pudo poner de manifiesto cabalmente, porque al no salir la parte más grande del ejército, menos podían hacerlo los civiles, que son una fuerza desarmada y por tanto secundaria en un movimiento de esta naturaleza.

-Sin embargo el enemigo aplicó el terror sobre el pueblo desarmado.

J. T. - Exacto, y eso lo pudimos comprobar en carne propia. Cuando nos detuvieron en el año 1956 nosotros pensamos que podíamos estar unos días detenidos y que nos largarían después, pues lo que habíamos hecho no revestía gravedad: organizar una marcha hacia Plaza de Mayo para pedir la vuelta de Perón no podía significar una pena de muerte. Sin embargo era necesario hacer correr sangre de nuevo - como en el 55-, demostrar cuál era el procedimiento que iban a adoptar ante todo tipo de reacción. La gravedad del papel desempeñado por la oligarquía y la antipatria sólo se iba a comprender con los asesinatos en los basurales de León Suárez, con las torturas y la cárcel, vinculándolos con el anterior bombardeo a Plaza de Mayo. Era el odio al pueblo manifiesto abiertamente. 
- ¿Como fue la detención?

J. T. - La efectuó el coronel Desiderio Fernández Suárez, quien se llevó a toda la gente de la casa de Florida con un colectivo de la línea 19. Mientras tanto Benavídez y yo estábamos recorriendo los grupos que teníamos en la calle. De modo que nuestra detención fue posterior a la de los restantes compañeros. No vimos cuando Suárez golpeó a Gavino; eso nos lo contaron después los compañeros.

- ¿Dónde se encontraron con Gavino y los demás?

J. T. - En la Unidad Regional de San Martín, luego de pasar por la comisaría 2o de Florida; a ellos en cambio los llevaron directamente a San Martín. Es decir, que a Fernández Suárez no lo conocí hasta el año 57, cuando me picanearon

- ¿Cuándo supieron que iban a ser fusilados?

J. T. - Creo que el calificativo de fusilamiento está mal aplicado, porque se trató de un vulgar asesinato. No hubo siquiera un juicio sumarísimo ni una notificación. Se nos transportó a un lugar - a los basurales de José León Suárez- y de pronto comenzaron a tirar sobre los compañeros. Nadie sabía nada de nada y de repente algunos encontraron que tenían un tiro encima. Eso es lo que después dieron a llamar fusilamientos. Yo creía que simplemente nos trasladaban de un lugar a otro. Pensé que nos llevaban a San Isidro, tal vez al Hipódromo porque habría gran cantidad de detenidos...Pero de ninguna manera que nos iban a matar. Ni remotamente.

- No lo pensaban antes ni les dieron oportunidad de pensarlo después, porque se enteraron de que los policías tenían orden de matarlos cuando ya estaban tirando...

J. T. - Así fué.

¿¿Qué tipo de interrogatorio les hicieron? 
J.T. - Un interrogatorio elemental, pacífico, como para llenar una formalidad y cubrir los requisitos legales. (Al principio parece que había dudas, luego, cuando confirmaron el fracaso del golpe, vino la orden de los asesinatos). El código señala la obligación de notificarle a uno porqué se encuentra detenido y de qué se lo acusa, pero a nosotros ni siquiera se nos tomó la declaración como imputados.

- ¿Cuáles fueron los acontecimientos en la Unidad Regional de San Martín? ¿Reconoció a alguien de la policía que hubiera trabajado con usted?*

J. T. - Sí, un compañero que había tenido un grado más que yo en la Policía fue quien me tomó declaración. Buen compañero ese, pero ahí estaba subordinado a los militares, que entraban y salían. Habían estado en cabildeos hasta que al fin llegó la orden que nosotros íbamos a conocer en la forma que conté. De allí nos sacaron en un camión de asalto de la Policía. Detrás venía una camioneta.

¿ ¿Por qué creés que nos les tiraron en la propia regional?

J. T. -Pienso que en la propia regional tendría más gravedad para ellos. Se trataba de una zona poblada; se oirían los disparos y después tendrían que sacar los muertos. Posiblemente se nos pretendía matar allá en los basurales y dejarnos tirados para después negar toda detención. Porque cuando conseguí llegar hasta casa y le pedí a mi padre que fuera a la comisaría $2^{\circ}$ de Vicente López a preguntar por mí le dijeron que no sabían nada, que yo no había estado detenido en ese lugar. Y en la Unidad Regional San Martín también le dijeron lo mismo. Aparentemente se pretendía negar la autoría se esos hechos, tal como se hizo después: desaparece gente y nadie se la llevó, aparecen muertos y nadie los mató.

-Sin embargo a los militares los mataron en la Penitenciaría o en el Regimiento

J. T. - Para entender todo esto hay que ponerse en el lugar de un tipo que estuvo en la Policía toda su vida, a quien le dan orden de fusilar a un grupo de detenidos. Qué sabe de esas cosas, qué complicación, qué compromiso. Matar así a sangre fría, sabiendo perfectamente que es una monstruosidad, una injusticia. Evidentemente hubo en lo que 
se hizo una torpeza brutal, ninguna especie de planificación. De ahí el resultado conocido: que la mayoría se escapó. Los condenados éramos once y resultaron cuatro los muertos y un herido.

¿¿Con qué les tiraron?

J. T. - Carabinas, pistolas cuarenta y cinco; no sé si había ametralladoras. Posiblemente trajeran alguna en la camioneta. Pero en un momento disparan tantas armas que no sé si dispararon ametralladoras o no. Ni sé a quién le tiraban tanto.

¿¿Cuando los hicieron bajar se dieron cuenta de que los iban a matar?

J.T.- No. Aunque yo no bajé. Dijeron "bajen seis" o algo así. Y bueno, obedecieron otros y yo me quedé arriba. Ya no me gustaba el asunto. Pensé que era mejor quedarse arriba; sobre todo porque tenía dos vigilantes al lado.

¿ ¿Esos vigilantes eran conocidos?

J. T. - No, pero en determinado momento es mejor tenerlos al lado por la posibilidad de arrebatar un arma. Es una posición mejor que la de los de abajo, todos alineados en el campo, ubicados.

¿¿Los veía a los demás?

J. T. -No. Veía en cambio a la camioneta que venía atrás y cuando bajaron tenía los faros prendidos alumbrando hacia ellos. Yo quería ver y agarré la loneta de ese lado para apartarla pero el vigilante me dijo: "No, no". "¿Qué pasa?", pregunté. "Nada, nada", contestó. Medio temblaba el vigilante. Y se oyó una voz de abajo: "¡No, no! ¡Cómo van a hacer eso!". Y en seguida el primer disparo. Luego todo se sucedió muy rápidamente. Yo agarro los dos cañones de las carabinas que tienen los vigilantes a mi lado. Ahí empieza un forcejeo. Otro vigilante que está al frente hace un disparo que le pega a Mario Brión en el pecho. Mario Brión se agarra el pecho y no se mueve más. Murió en el acto. Estaba un asiento más adelante; en lugar de pegarme a mí el disparo lo alcanzó a él. 
Inmediatamente empujo con violencia a los dos vigilantes que caen contra la loneta. No les podía arrebatar una de las dos carabinas. Además no las podía soltar. Pero igual me largo del otro lado. Se había tirado Benavídez en ese momento, que estaba expectante viendo lo que hacía yo. Era una noche sin luna. En cuanto me largo del camión hago un cuerpo a tierra y se produjo una descarga, la primera descarga de los vigilantes hacia mí. Una bala me rozó la oreja derecha. No sabía si me había pegado o no. Un estampido bárbaro en la oreja y el zumbido de la bala. Así hice luego otro cuerpo a tierra y ya en la oscuridad me perdí. Evidentemente los policías que estaban abajo y tenían la tarea de matar a los demás compañeros se dieron vuelta al oír esos disparos detrás de ellos, circunstancia que aprovechó la mayoría para escaparse. Eso le salvó la vida a varios. Precisamente ese incidente en el carro de asalto fue el que brindó la posibilidad de que se salvaran tantos. Si no, nos hubieran matado como corderos.

\section{- ¿La policía sabía a quienes llevaba a matar?}

J. T. -No sé, porque los vigilantes no querían hablar. Seguramente tenían órdenes en ese sentido. Por otra parte nosotros íbamos sin sospechar nada. Hasta qué punto era así que pocos metros antes de llegar al lugar donde se produjeron los hechos se descompuso el chofer y dijo: "¿Hay alguien que sepa manejar?". Y Benavídez le contestó: "Yo". Y Díaz estaba roncando al lado mío. Por dónde bajó Díaz no sé, de pronto desapareció. Yo lo tenía al lado a él y de repente lo encuentro a Pedrito Lizaso. No sé en qué momento se tiró. Pero en el camión roncaba. Yo quería comunicarme con alguien y no podía.

- ¿A qué atribuye la detención del núcleo de Florida?

J. T. - Al parecer alguno de los integrantes del grupo hizo lo que muchos: habló demasiado. No sé cómo se enteró que el general Tanco participaba del movimiento; tal vez comentó por ahí que el general Tanco iba a concurrir a nuestro grupo.

-¿Le preguntaron por el general? 
J. T. - A mí no. Al que le preguntaron fue a Gavino. El coronel Fernández Suárez lo golpeó, le puso la pistola en la boca preguntándole por Tanco. Gavino sabía tanto de Tanco como yo...

-¿Quiere decir que la detención derivó de una imprudencia y no de que hubiera infiltrados?

J. T.- Bueno, el grupo cometió el error de llevar gente no completamente confiable. Benavídez y yo dejamos a los compañeros en la calle, en bares, distribuidos aquí y allá. Otros llevaron gente que nunca habíamos visto. De ahí pudo haber salido la infidencia, por supuesto.

¿¿Los gorilas eligieron ese grupo al azar para asesinarlo?

J.T.- Exactamente. Desvirtuado lo del general Tanco, que allí no estaba y de quien nadie sabía nada, se ordenó lisa y llanamente el asesinato en masa. Era un grupo al que se le aplicaba el terror para que el resto de la población dijera: "Lo que les pasó a ellos nos puede pasar a nosotros si nos metemos". En suma, un escarmiento criminal, cruel y sangriento amparado en la impunidad de la fuerza.

- ¿Lo hizo dudar de la fuerza de la causa el hecho de que no se produjese una reacción masiva inmediata?

J. T.- Sólo algunas veces me sentí un poco decepcionado: no obstante en el 56 se realizó la Marcha del Silencio por los asesinatos. Yo no estaba en el país, pero sé que la concurrencia fue de miles. El hecho posterior más saliente y que me provocó gran alegría fue el Cordobazo; ahí quedó demostrado bien palpablemente que el pueblo no se mantiene retraído. Cuando se le presenta una oportunidad de ganar la calle sale a pelear. Y eso no se limitó a Córdoba, sino que se repitió en Tucumán, en Salta, en Cipolletti, en Rosario, en Mendoza, lo cual nos demuestra que en el momento necesario la población va a participar activamente en el proceso revolucionario. La extensión del proceso, manteniendo la línea, facilita una profundización de la conciencia de la clase trabajadora 
peronista. Se recogen las experiencias derivadas de haber probado unas cuantas formas de lucha y se las aplica en el camino de la reconquista del poder.

* Julio Troxler perteneció a la Policía de la Provincia de Buenos Aires y su exoneración, producida durante el período del gobierno peronista, se debió a haberse retirado de la repartición sin esperar a que el Poder Ejecutivo de la Provincia de Buenos Aires aceptase su renuncia. Con respecto a los motivos que lo llevaron a alejarse de esa función pública, el propio Julio explica: "Mi actitud obedeció a que en el momento de entrar a la repartición tenía un concepto de la función policial que juzgué desvirtuado por algunos elementos que no eran fieles servidores públicos. Mucho después comprendí que esos males que yo denunciaba en la repartición eran males menores, quizá inevitables en la Policía. Al lado de la institución policial que conocí luego del derrocamiento de Perón, aquella era buena. Hoy la policía mata impunemente. En la época de Perón por una cachetada que se le daba a cualquiera caía un instructor de La Plata, se labraba un sumario con intervención del juez y el autor del abuso de autoridad se veía en un serio aprieto. Actualmente parece que para los ascensos es tomado en consideración el número de muertos. Es decir que la situación de la policía ha cambiado sustancialmente. Aquella era una policía al servicio del pueblo; ésta es una policía al servicio del régimen."

Extraído de "Peronismo y Socialismo" Nro. 1 Sep. 1973 www.lucheyvuelve.com.br 